Andrews University

Digital Commons @ Andrews University

1982

\title{
The Necessary Job Competencies of Secondary School Principals as Perceived by School Administrators in Sabah, Malaysia
}

Charles Saimin Gaban

Andrews University

Follow this and additional works at: https://digitalcommons.andrews.edu/dissertations

Part of the Educational Administration and Supervision Commons, and the Secondary Education Commons

\section{Recommended Citation}

Gaban, Charles Saimin, "The Necessary Job Competencies of Secondary School Principals as Perceived by School Administrators in Sabah, Malaysia" (1982). Dissertations. 382.

https://digitalcommons.andrews.edu/dissertations/382

https://dx.doi.org/10.32597/dissertations/382

This Dissertation is brought to you for free and open access by the Graduate Research at Digital Commons @ Andrews University. It has been accepted for inclusion in Dissertations by an authorized administrator of Digital Commons@ Andrews University. For more information, please contact repository@andrews.edu. 


\section{Andrews \$university}

Seek Knowledge. Affirm Faith. Change the World.

Thank you for your interest in the

\section{Andrews University Digital Library of Dissertations and Theses.}

Please honor the copyright of this document by not duplicating or distributing additional copies in any form without the author's express written permission. Thanks for your cooperation. 


\section{I.NFORMATION TO USERS}

Thu reproductuon wats mate trom a cons of a document sent to us for microfilming. Whale the most devanced tedhnology has been used to photograph and reproduce this document. the quality il the expoduction is heavily dependent upon the yuality ot tilc masion! suthm!rted.

The following explanation of echniques is provided to help elarity markings or notations which may appear on this reproduction.

1. The itgn or "target" for pages upparently lacking from the document photographed is "Missing Page(s)". If it was possible to obtain the missing nage? sl or section. they are spliced into the tilm along with adjacent pages. This may have necessitated cutting through an image and duplicating adjacent pages to assure complete continuty.

2. When an image on the tilm is obliterated with a round black mark. it is an indication of either blured copy because of movement during exposure. duplicate copy, or copyrighted materials that should not have been filmed. For blurreu pages. a good image of the page can be lound in the adjacent frame. If copyrighted materials were deleted. a target note will appear listing the pages in the adjacent trame.

3. When a map. drawing or chart. etc.. is part of the material being photographed, I detinite method of "sectioning" the material has been iollowed. It is sustomary to begin rilmine at the upper left hand comer of a large sheet and to continue from kett to right in equal sections with small overlaps. If necessary. xectioning is continued dyain heginning below the first row and continuing on antil complete.

4. For illustrations that cannot be satisfactorily reproduced by xerograpinic means. photographic prants ian be ptirchased at aduitional cost and inserted into your verographic cony. These pnnts are available upon request from the Dissertations Customer Services Department.

S. Some pages in any documient may have indistinct print. In all cases the best

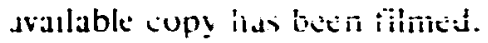


Reproduced with permission of the copyright owner. Further reproduction prohibited without permission. 
Gaban, Charles Saimin

THE NECESSARY JCB COMPETENCIES OF SECONDARY SCHOOL PRINCIPALS AS PERCEIVED BY SCHOOL ADMINISTRATORS IN SABAH, MALAYSIA

Andrews University

ED.D. 1982

\author{
University \\ Microfilms \\ International son' zeeo Road. Ann Arbor. M1 48106
}


Reproduced with permission of the copyright owner. Further reproduction prohibited without permission. 
in all cases this material has been filmed in the best possible way from the available copy.

Problems encountered with this document have been identified here with a check mark

1. Glossy photographs or pages

2. Colored illustrations, paper or print

3. Photographs with dark background

4. Illustrations are poor copy

5. Pages with black marks, not original copy

6. Print shows through as there is text on both sides of page

7. Indistinct, broker, or small print on several pages

8. Print exceeds margin requirements

9. Tightly bound copy with print lost in spine

10. Computer frintout pages with indistinct print

11. Page(s) lacking when material received. and not available from school or author.

12. Page(s) seem to be missing in numbering only as text follows.

i3. Two pages numbered Text follows.

14. Curling and wrinkled pages

15. Other

\section{University Microfi!ms International}


Reproduced with permission of the copyright owner. Further reproduction prohibited without permission. 


\title{
Andrews University \\ School of Grzduate Studies
}

THE NECESSARY JOB COMPETENCIES OF SECONDARY

SCHOOL PRINCIPALS AS PERCEIVED BY SCHOOL ADMINISTRATORS IN

SABAH, MALAYSIA

\author{
A Dissertation \\ Presented in Partial Fulfillment \\ of the Requirements for the Degree \\ Doctor of Education
}

by

Charles Saimin Gaban

June 1982

Reproduced with permission of the copyright owner. Further reproduction prohibited without permission. 


\title{
THE NECESSARY JOE COHPETENCIES OF SECONDARY \\ SCHOOL DR IIVEIPALS AS PERCEIVED BY \\ SCHOOL ADMINISTRATORS IN \\ SABAH, HALAYSIA
}

\author{
A dissertation \\ presented in partial fulfillment \\ of the requirements for the degree \\ Doctor of Education
}

by

Charles S. Gaban

APPROVAL BY THE COMHITTEE:

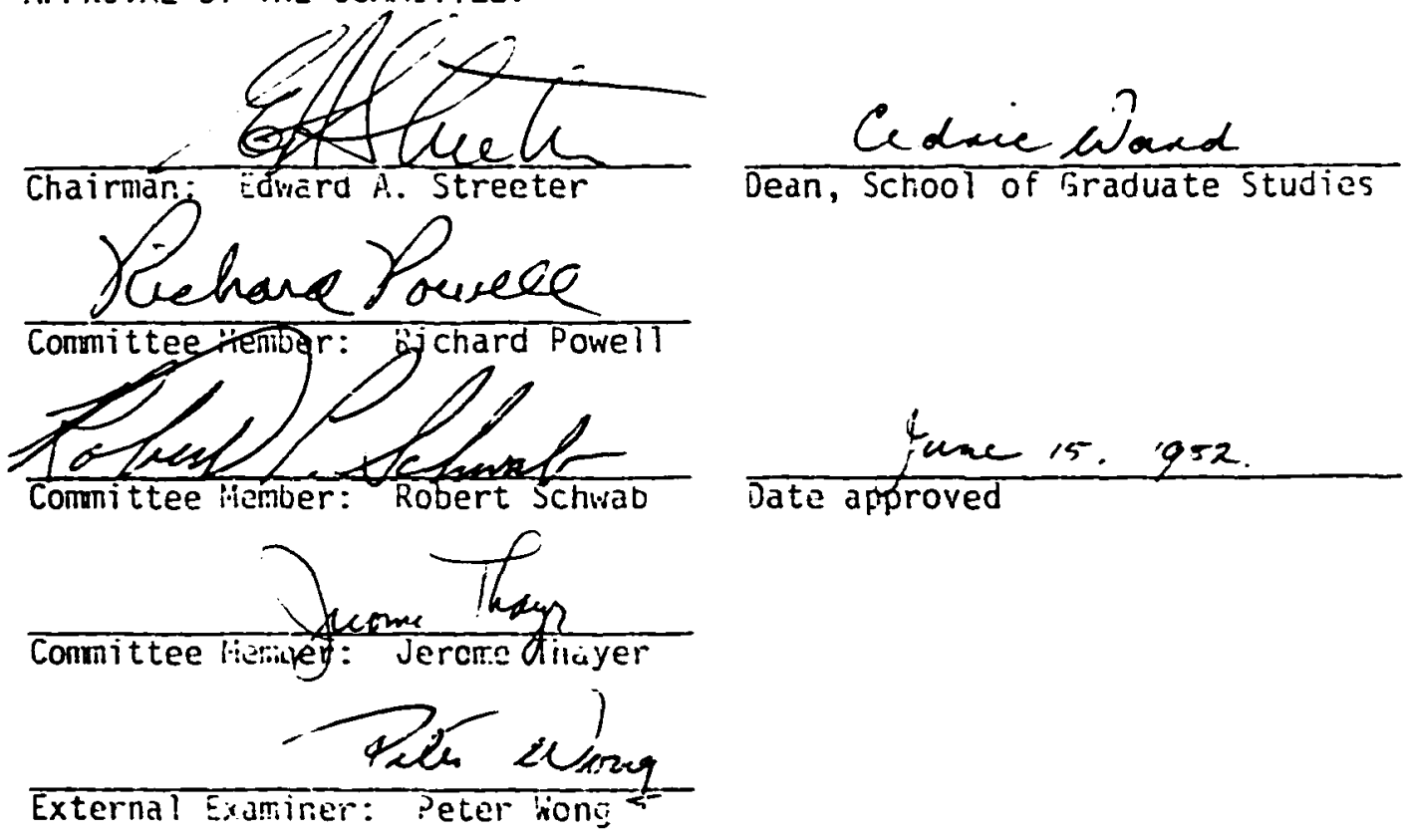

Reproduced with permission of the copyright owner. Further reproduction prohibited without permission. 


\section{ABSTRACT}

\section{THE NECESSARY JOB COMPETENCIES OF SECONDARY SCHOOL PRINCIPALS AS PERCEIVED BY SCHOOL ADMINISTRATORS IN SABAH, MALAYSIA}

\section{by}

Charles S. Gaban

Chaiman: Edward A. Streeter 


\section{ABSTRACT OF GRADUATE STUDENT RESEARCH \\ Dissertation}

Andrews University

School of Graduate Studies

it ite: THE NECESSARY JOB COMPETENCIES OF SECONDARY SCHOOL PRINCIPALS AS PERCEIVED BY SCHOOL ADMINISTRATORS IN SABAH, MALAYSIA

Vame of researcher: Charles S. Gaban

Vame and degree of faculty advisor: Edward A. Streeter, Ed.D.

Jate completed: June 1982

Purpose

This study sought to determine the necessary competencies for secondary-school principalship functions as perceived by educational administrators in Sabah. A secondary purpose was to identify the most feasible time for acquiring the competencies.

\section{Method}

The subjects for this study were three groups of administraEors: principals, inspectors, and central office personnel. All the 159 secondary-school principals, inspectors, and central office personnel identified in the study were included. 
i questionnaire was utilized to gather the data. Of the 159 respondents, 116 (72 percent) returned the questionnaires. A fourjoint Likert-type scale was used to indicate the essentiality of each competency statement. Two non-parametric statistical tests (Chisquare and Kendall's concordance) were utilized in the analys is of the data.

\section{Results}

The respondent groups did not differ significantly in their perceptions on the essentiality of 41 of the forty-three competencies included in this study. All these competencies were considered important skills although some were perceived as more essential than others.

in the analysis of the procedure for acquiring the competencies, significant differences were noted among the perceptions of the groups on nine of the competencies. Analysis of the responses in wich there was agreement among the perceptions of the respondents indicated that the groups saw more than one feasible procedure for acquiring the competencies. The total population saw that five of the competencies could be developed through pre-service course work, twenty-seven through in-service programs, and twenty-eight through experience on the job.

\section{Recommendations}

The following recommendations are offered as a result of the conclusions drawn from this study:

1. The personnel of the Department of Education who plan for pre-service and in-service training programs for principals in Sabah 
snould consider the results of this study to arrive a $\tau$ meaningful and reievant programs for principals.

2. In planning for in-service programs for principals, comnunication between the inspectors, principals, and central office personnel should be improved.

3. The Department of Education should provide the principals with more opportunities tc do advanced course work in educational administration.

4. Institutions that provide courses in educational administration should re-e:aluate their course offerings so that they are relevant to the actual work the principals periorm in the schools. 
TABLE OF CONTENTS

LIST OF TABLES .................... . . . . . iv

ICKNOWLEDGEMENTS .................... . . vii

Chapter

I. INTRODUCTION ............................ 1

Statement of the Probien ............. 3

The Purpose of the Study . . . . . . . . . . . 3

Sub-purposes ................. . 3

Significance of This study . . . . . . . . . . . 4

Delimitations.................. . . . . . 4

Assumptions .................. . . . . 5

Hypotheses ................. . . . . 5

Jefinition of Terms............. . . . 5

Organization of the Study............. 6

:I. REVIEN OF RELATED LITERATURE . . . . . . . . . . . . . . 3

Competency Movement ................. 8

Administrative Competencies........... . . 11

Professional Preparation of Principals ........ 23

Educational System in Sabah............ . 26

Historical background.............. . . 26

The structure of educational system........ 28

The administration of education......... 30

Summary.................. . 31

:II. METHODOLOGY . . . . . . . . . . . . . . . . 33

Sub.jects of the study... . . . . . . . . . . 33

Instrumentation............... 34

Collectior of Jata ................ . . 35

Analys is of Data ................ 36

iV. PRESENTATION OF FINDINGS . . . . . . . . . . . . 38

Analysis of Competency Statements .......... . 40

Policy development ............. . 40

Business affairs: budget, accounting,
purchasing .................... 43 
Eommunity services and comiunity

relations............... . . . 46

Puoil personnel services: guidance

and counseling services........... . 49

student activities--including

music and sports .............. 52

?upil control: discipline, attendance ................ 55

3uilding-level organization and control of school plant........... . 57

Auxiliary services: cafeteria, nealth, and safety ............ . . o o

Staff personnel: assignment, working conditions, certification and classification .......

Staff improvement: evaluation, in-service training, and involvement

in policy formation.............

Program evaluation and planning, curriculum development, and instruction ............... . . 68

Research and development projects, investigation and testing of new techniques, innovations and change ...... 71

Ranking of the Twelve Administrative

Task Areas .................. . . 74

Summary of the Essentiality of the Competencies

and the Procedure for Acquiring Them . . . . . . 78

Research Hypotheses............... 30

$\%$ SUMMARY, CONCLUSIONS, AND RECOMMENDATIONS . . . . . . . 34

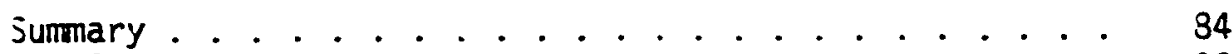

Conclusions .. . . . . . . . . . . . . . 93

Recommendations............... . . 94

APPENDICES .............................. 97

A. Vames and iddresses of Panel of judges... . . . . . 97

3. Competency Statements .. . . . . . . . . . . . . 98

C. The Questionnaire ............... 101

J. Covering and Follow-up Letters to Respondents ................. 106

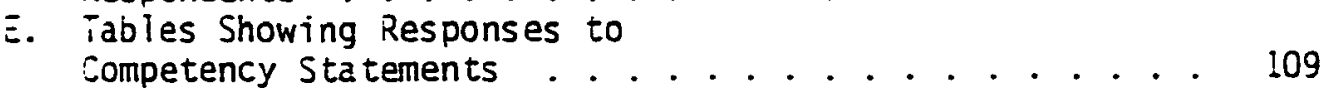

BIBLIOGRAPHY . . . . . . . . . . . . . . . 152

VITA ..................... 157 
1. Student Enrollment . . . . . . . . . . . . . 29

2. Rate of Return of Questionnaires........... 36

3. Responses to Administrative Task Area:

Policy Development . . . . . . . . . . . . . 41

4. Responses to Administrative Task Area:

Business Affairs................... 44

5. Responses to Administrative Task Area:

Community Services and Community Relations....... . 47

6. Responses to Administrative Task Area:

Pupil Personnel Services... . . . . . . . . . . 50

7. Responses to Administrative Task Area:

Student Activities.............. 53

3. Responses to Administrative Task Area:

Pupil Control ................... . . 56

3. Responses to Administrative Task Area: Building Level

Drganization and Control of School Plant........ 58

10. Responses to Administrative Task Area:

Huxiliary Services................. 61

11. Responses to Administrative Task Area:

Staff Personnel ................ . . ó3

12. Responses to Administrative Task Area:

Staff improvement ............... 57

13. Responses to Administrative Task Area: Program Evaluation and Planning, Curriculum Development, and instruction ................. 70

14. Responses to Administrative Task Area: Research and Development Projects, Investigation and Testing of New

Techniques, innovations and Change.......... 
:三. Ranking jcores oi the Tweive Administrative Task Areas

כy Princidals, inspectors, and Central Office

16. Ranking of the Twelve Administrative Task Areas by

Principais................ . . . 76

i7. Ranking of the Twelve Administrative Task Areas by

Inspectors . . . . . . . . . . . . . . 76

18. Ranking of the Twelve Administrative Task Areas by

Central office Personnel.............. i7

19. Combined Ranking of Administrative Task Areas by

Principals, Inspectors, and Central Office

Personnel.................. 79

20. Summary of the Perceptions of the Principals, Inspectors, and Central Office Personnel on Procedures in which They

Differed Significantly............. 81

21. Responses to Competency I ... . . . . . . . . . 109

22. Responses to Competency 2 . . . . . . . . . . . . . 110

23. Responses to Competency 3.............. 111

24. Responses to Competency 4 ................ $\$ 12$

25. Responses to Competency 5 ............... 113

26. Responses to Competency o . . . . . . . . . . . . . . 114

27. Responses to Competency 7 ............. 115

28. Responses to Competency 3 ............... 116

29. Responses to Competency 9 . . . . . . . . . . . 117

30. Responses to Competency 10 . . . . . . . . . . 118

31. Responses to Competency II . . . . . . . . . . . I19

32. Responses to Competency i2 . . . . . . . . . . i20

33. Responses to Competency i3 . . . . . . . . . . 121

34. Responses to Competency 14 . . . . . . . . 122

35. Responses to Competency I5 .............. 123

36. 3esponses to Competency 16 ............ 124

v 
37. Responses to Competency 17 . . . . . . . . . . . . 125

38. Responses to Competency 18 . . . . . . . . . . . . 126

39. Responses to Competency 19 . . . . . . . . . . 127

40. Responses to Competency 20 . . . . . . . . . . I28

41. Responses to Competency 21 . . . . . . . . . . . 129

42. Responses to Competency 22 . . . . . . . . . . . . . . . 130

43. Responses to Competency 23 . . . . . . . . . . . . $\$ 31$

44. Responses to Competency 24 . . . . . . . . . . . . . 132

45. Responses to Competency 25 . . . . . . . . . . . 133

46. Responses to Competency 26 . . . . . . . . . . . . 134

47. Responses to Competency 27 . . . . . . . . . . . . . 35

48. Responses to Competency 28 . . . . . . . . . . . . 136

49. Responses to Competency 29 . . . . . . . . . . . . 137

50. Responses to Competency 30 . . . . . . . . . . . . 138

51. Responses to Competency 31 . . . . . . . . . . . . 139

52. Responses to Competency 32 . . . . . . . . . . . 140

53. Responses to Competency 33 . . . . . . . . . . . 141

54. Responses to Competency 34 . . . . . . . . . . . . 142

55. Responses to Competency 35 . . . . . . . . . . . 143

56. Responses to Competency 36 . . . . . . . . . . . . . 144

57. Responses to Competency 37 . . . . . . . . . . . . 145

58. Responses to Competency 38 . . . . . . . . . . . . 146

59. Responses to Competency 39 . . . . . . . . . . . 147

60. Responses to Competency 40 . . . . . . . . . . 148

61. Responses to Competency 41 ............ 149

б2. Responses to Competency 42 . . . . . . . . . . . 150

63. Responses to Competency 43 ............. 151

vi 


\section{ACKNOWLEDGEMENTS}

I wish to express my deepest gratitude and sincerest appreciation to those who assisted me in the pursuit of this research.

io my dissertation committee members: Or. Edward A. Streeter for his assistance and encouragement, Dr. Jerome D. Thayer for his assistance in the statistical analysis, and Drs. Robert $\mathcal{C}$. Schwab and Richard K. Powell for their valuable suggestions;

io my brother, Herbert, for his assistance in distributing the questionnaire to the respondents and mailing them back to me;

To Mrs. Joyce Jones for editing the manuscript;

io Sabar Foundation ior the financial assistance given to me in the pursuit of my doctoral program;

And firially to my wife, Connie, and my children, Cheri, Eivin, and walter for their patience and understanding throughout the preparation of this study.

vii 
CHAPTER I

INTRODUCTION

ine competency of school administrators is of critical concern and interest in the school system. This is due to the belief that the competence of the administrator of a school has a strong influence on the effectiveness of its instructional program. According to Trump (1972) the principal does more to influence the quality of the school program than any other person. The accomplishments of teachers and superintendents are greatly enhanced or restricted by the actions of the principals.

The movement toward increased accountability and new approaches to instruction are stressing the importance of skill competency. The Vational Association of Secondary School Principals says, "The principal is a curriculum analyst, executive, interpreter, manager, mediator, omcutsman, scholar, strategist, and teacher of teachers" (Weldy, 1979, i. 195). This jocus is not neit. "ntz (1955) categorized the skills needed by administrators as conceptual, numan, and techrical skills, listed in hierarchical order with conceptual skills being related to top-levei management. Human relations skills were associated with the middle-ievel management, while technical skiils were associated with the lower level. 
Austin (1974) asserts that the recognition of the change in ieadersnip roles of the principals has caused a revolution of college training programs, certification standards, and practices. One such practice is a movement toward training and certification programs jased upon the demonstration of the competency to perform the job effectively.

in discussing the use of competency specifications for professional development, Harris, McIntyre, Littleton, and Long (1979) assert:

Although we do not take the position that all training activities must be shaped in the competency mold, welidesigned lists of needed competencies could very well provide the framework for planning many such activities. (p. 124)

Castetter (1981) notes that despite significant criticism of the competency-based movement in teacher education, competency lists nave made a contribution to the personnel function in the development of improved position guides, and in the improvement of the recruitment, selection, and induction process.

interest in competency-based teacher eduration has also been expressed by educational leaders in Malaysia and the surrounding countries. The main purpose of the seminar he?d in Thailand in 1978 oy the Asian Programme of Educational Innovation for Development (APEID) was to discuss alternative approacnes in the preparation of educational personnel and the application of new techniques. The discussion included the need for selecting appropriate competencies and setting them in a priority order for training programs (UNESCO, 1979). 


\section{Statement of the Problem}

Sabah is one of the fourteen states in the Federation of ialaysia. According to the statistical data in the Department of Education (1977), a iarge number of secondary schools, vocational ard teacher-training colleges in Sabah need trained and qualiried Jersonnel. Taha (1979) confirmed this in his research concerning zeacher education in Saban. The report of Malaysia to the APEID seminar held in the Philippines on September 1980 indicated that the Ministry of Education of Malaysia was putting forth effort to uplift the professional competence of teachers through both preservice and in-service education programs (UNESCO, 1980). A welldesigned list of competencies were needed for the planning of such activities. is far as can be determined, no such research has undertaken to identify the competencies needed by school principals in Saban.

\section{The Purpose of the Study}

The purpose of this study was to determine the competencies necessary for administrative functions of secondary schools as perceived by the central office personnel, school inspectors, and secondary school principals in Sabah.

\section{Sub-purposes}

In order to accomplish an adequate treatment of the problem, the following sub-purposes were identified:

1. To investigate studies indertaken in the area of administrative competencies and attempt to do a similar investigation in Saban. 
2. in determine when the respondents perceive the most ieasible time for developing these competencies--during pre-service, chrough in-service, or experience on the job.

3. To determine how the respondent groups differ in their perceptions of tile importance of the competencies and the procedure by wnich they are to be acquired.

\section{Significance of This Study}

In Sabah there is an increasing awareness among educational personnel of the importance of in-service education as a means of professiona! growth for teachers and administrators. In-service education programs are organized and conducted in various forms. The findings of this investigation should be of value to the school inspectors and supervisors in planning for pre-service and in-service programs. The findings could also be used in supporting new directions for pre-service and in-service training for principals. Instiiutions that orepare individuals for principalship responsibilities could utilize the findings to determine if their programs are adequately addressing the areas the respondents perceive as being important.

\section{Del imitations}

The population of this study was delimited to the school inspectors, secondary-school principals, and central office administrative personnel employed in the Department of Education of Sabah in 1981 .

No attempt was made to include all conceivable minor competencies for secondary-school principalship. 
issumptions

it was assumed in this study that the administrative personnel of the Department of Education, school inspectors, and principals were the best qualified persons available to identify the competencies for the performance of the duties of secondary-scnool principals in Sabah.

\section{Hypotheses}

Since the identification of the competencies was based on the perceptions of the central office administrative personnel, school inspectors, and principals the following research hypotheses were postulated:

1. There is no significant difference between the perceptions of the central office administrative personnel, school inspectors, and priricipals on the importance of competencies needed for secondaryschool principalship.

2. There is no significant difference between the perceptions of the central ofice administrative personnel, school inspectors, and principals on the procedures for acquiring these competencies.

\section{Definition of Terms}

APEID: The acronym APEID refers to the Asian Programe of Educational innovation for Jevelopment. Its members include Afghanistan, Australia, Bangladesh, India, Indonesia, iran, Japan, Republic of Korea, Lao People's Democratic Republic, Malaysia, Nepal, Pakistan, Papua New Guinea, Philippines, Singapore, Sri Lanka, Thailand, and Socialist Republic of 'ietnam. Its aim is to stimulate and encourage educational innovations linked to the problems of national development in the Asian region. 
ientral office aministrative personnel: Administrative personnel at the central office includes the Director of Education, Deputy Jirector of Education, Assistant Directors of Education, Regional Education Officers, and Departmental Officers. Competency: The capacity to perform administrative tasks at a satisfactory level of performance that satisfies the requirements of a specified position, such as the secondary-school principalship, is the meaning for competency.

School inspectors: Educational personnel who are members of the School Inspectorate Board of Sabah are the school inspectors. Their main functions are to visit schools and report on all aspects of the school administration and management to the state Director of Education and to the Federal Chief Inspector of schools. They also advise school principals and teachers on how to implement educational policies.

Secondary schools: For the purpose of this study, the term secondary schools refers to both the junior and senior high schools in Sabah.

\section{Organization of the Study}

The study is organized into five chapters:

Chapter I presents the background of the study, the problem, the purpose, sub-purposes, and significance of the study, the Iimitations, the assumptions, the hypotheses, and the definition of terms.

Cinapter II consists of a review of the literature which includes the educational system of Sabah, the competency-movement, 
ine aaministrative competencies, and the professional preparation of principais.

Chapter I:I presents an explaliation of the methods employed in conducting the survey. The presentation includes the subjects, instrumentation, and procedures followed in collecting and analyzing the data.

Chapter IV reports the findings and interprets the results while chapter $V$ contains a summary of the findings of the study, pertinent conclusions, and recommendations. 


\section{CHAPTER II}

\section{REVIEN OF RELATED LITERATURE}

This cnapter consists of four sections: (1) a survey of the competency-based movement in teacher preparation programs, (2) a survey of related literature on administrative competencies, (3) a sumnary of the professional preparation of principals, and (4) a review of literatures on the educational system of Sabah. The review of the literatures on the history, structure, and administration of education in Sabah was undertaken to provide an understanding of the educational system.

\section{Competency Movement}

The competency-based movement in teacher preparation programs appears to be widespread in the United States. its origin and extent are described in this section.

Rosener and Kay (1974) claimed that the compotency-based education movement had its origin in the late sixties. However, ooinions vary regarding what brought forth this movement. Elam (1971) suggested that the social conditions of the sixties probably contributed to the birth of the competency-based movement. He noted that the traditional teacher preparatory programs were being criticized for their inability to prepare teachers to work with minority children. 
Scnmeider (1973) identified the following as the beginning of the competency rovement: (I) the continual and conscientious introspection of the education community, (2) the press for accountability, (3) the increased focusing of political action on fiscal issues, (4) the management organizational movement, (5) the press for personalization/individuaization of education departments to develop more effective certification processes and standards, (7) the investment of federal funds in competency-based education development efforts, (3) the readiness of educational $R$ and $D$, and (9) the increase in alternative educational systems with resulting need for dependable measures of comparison.

Houston (1974) believed the movement evolved from the influence of two factors: the press for accountability and the need for more personalization. With increasing budgets and restricted funds, society pressed educators to relate systems input (dollars, personnel, building, resources) to systems output (increased student achievement related to goals of the society). He also said that the same cultural press (accountability) had caused the development of management by objectives (MBO), and planning, programing, and budgeting systems (PPBS).

Rosner and Kay (1974) contended that the concept was spurred on by increasing demands for accountability, relevance, and cost effective schooling, while Borich (1977) suggested that the origin of the movement may have been more "political than substantive".

The actual extent to which competency-based education was being implemented probably cannot be knowr, but Westbrook and 
Sandefur (1975) concluded that institutions were continuing to move sowara some competency-based teacher educational model. At the iederal level, the ilational Council on Education Profession Development (1976) recommended the continuance of the study of competencyJased education.

ihe competency-based education movement had also gained interest in Malaysia. Nong (1977) conducted a study to determine whether the concept of performance-based teacner education (PBTE) had a potential application to the ilalaysian teacher preparation programs. His study showed that some elements of teacher education in Malaysia were performance-based oriented. He recommended that a PBTE-type program starting at a modest size and growing as the need required should be introduced in Malaysia.

While originating in professional education as a movement to prepare teachers, competency-based education had also spread to many other fields: i.e., dentistry, social work, and business (Houston \& Narner, 1977).

Although the competency movement nad not permeated school administration preparation programs to the extent that it had in teacher preparation programs, there were a number of projects such as Project R.O.M.E. and studies involved in a systematic identification of competencies required for school administrators.

in response to the demand for accountability, Project R.O.M.E. (Results Oriented Management in Education) was implemented in Georgia for the purpose of identifying competencies needed by principals. This project was started at Thomas County during the spring of 1973 
as part of an on-going Managenient Objective Program. Project R.O.M.E. was involved in the identification and development, and professional yerification and vaiidation of competencies and performance indicators for building-level administrators in the state of Georgia. One aspect of this project was the utilization of the identified competencies in the development and implementation of a field-based training program model for school principals at Valdosta, Georgia, known as field Oriented Competency Utiiization Systems (FOCUS). A report of this program indicated that principals who had participated in the fieldoriented program perceived themselves as more competent at the termination of the FOCUS program than at its inception. Teachers who worked directly with the principals on school problems reported the principals more frequently and more effectively performed indicators of competency (Ellett, 1976).

Metzer (1976) presented a paper on a practical, researchbased program for the evaluation of administrativa performance. According to him, a definition of administrative competence and a reliable measuring instrument for assessing lavels of attainment were necessary elements of a competency-based program. Basic to the success of any competericy-based curriculum was the identification of the required competencies for a particular position. Sumaries of administrative competencies reviewed in this study appear below.

\section{Administrative Competencies}

Among the early studies in the area of administrative competencies was one conducted by the Soutinern States Cooperative Program in Educational Administration in 1951 (SSCPEA, 1955). This project 
was iunced oy the $\mathrm{N}$. K. Kellogg Foundation. The major purpose of the study was to obtain some consensus on the competencies needed by educational administrators. The group identified the following eight areas as the functional duties of educational administrators:

(1) instructional and curriculum development, (2) pupil personnel, (3) community-school leadership, (4) staff personnel, (5) school plant, (6) organization structure, (7) school finance and business management, and (8) transportation.

Woodward (1954) conducted a study to determine the competencies needed by school principals, superintendents, and supervisors in the state of Virginia. He found that the competencies needed by the three groups of administrators were similar. His primary conclusion was that the major portion of the pre-service training programs for prosjective school administrators should give major emphas is to the development of competencies in ten task areas: (1) function and scope of public education, (2) communication, (3) educational foundations, (4) human relations, (5) community relations, (6) curriculum, (7) instruction and guidance activities, (8) supervisory service, (9) evaluation and research, and (10) related educational agencies. Lawrence (1958) developed a source book with the assistance of secondary school principals, supervisors, and university professors of educational administration. The source book was intended for use in programing individual learning plans for administrative incerns and included six areas of a principal's responsibilities: (1) budget, (2) teacher evaluation, (3) community relations, (4) administrative procedures, (5) scheduling, and (6) comprehensive planning. 
i comprenensive siludy jointly conducted by the Research Foundation and the Department of Education at Oklahoma State University dealt with role expectations of principa!s as perceived by :eachers, principals, and superintendents. in general, the study revealed similarities among the respondents in their role expectations for principals in the areas of (1) budget preparation, (2) community relations, and (3) teacher observation and evaluation (Sweitzer, :963).

In a study of the priorities of the competencies needed in educational administration undertaken in 1966, Treblas found that superintendents of public schools and college professors agreed that preparation programs in educational administration snould stress the importance of: (1) the development of specific understandings and skills related to subject matter areas and managerial tasks, (2) development of general knowledge and skills related to the administration of the total school programs, and (3) development of human relations skills.

Alberto (1970) conducted a similar study on the priorities of competencies in educational administration. His study revealed that among the top competencies considered as very important were skills in planning, organizing, and evaluating the total school program. Such competencies were to be developed during pre-service training programs for educational administrators. Ranked as the next very important competencies were the development of tact and the ability to work with other people.

Martin (1972) reported that members of university departments of educationai administration generally agree that the administrative 
competency areas needing to be improved through in-service training programs for principals were: teacher evaluation, negotiations, concepts of labor relations in the public scnool setting, instructional role of the ; rincipal, team teacning, individualized instruction, educational systems and systems analysis, leadership skills, development and up-dating of staff, group dynamics, computer technology, clinical supervision, management problems and skills, due process, communication skills, the cnanging role of principals, and the metropolitan school principal.

The primary purpose of a study conducted by Cook and Van Otten (1972) under the sponsorship of the Kettering Foundation was to determine the basic competencies needed by principals as perceived by superintendents, secondary-school principals, and secondary-school teachers. They identified the following areas of competencies:

(1) districtwide policy development and board of education staff work, (2) business affairs-budget, accounting, and purchasing, (3) community services and community relations, (4) pupil personnel--guidance and counseling services, (5) student activities, including sports, (6) pupil controi--liscipline and attendance, (7) building-level organization and control of school plant, (8) auxiliary services-cafeteria, transportation, hea!th, and safety, (9) staff personnel-assignment, working conditions, certificacion, and classification, (10) staff improvement--evaluation, in-service training, involvement in policy formulation, (11) program evaluation and planning, curricuIum development, instruction, and (12) research and deveiopment project--investigation and testing of new techniques, innovation, and change. 
McCleary and Hcincyre (1972) developed a competency-based curriculum model to assist those who were involved in the preparation of programs for administrators. This model attempted to classify competencies to be mastered by the learner in terms of whether they were primarily technical, conceptual, or human in nature. They suggested that competencies in each of these areas should be mastered at some specified level of proficiency, familiarity, understanding, and application. Their assumptions were:

1. Learning is effective when the things to be learned are clearly specified--the learner understands what is to be accomplished, the prerequisite knowledge and skills are known and the learner possesses them, and the level of performance of what is to be learned is understood by the learner and teacher.

2. Teaching is effective when content (technical skills, conceptual understanding, and human factors) is identified and interrelated, when the methods of instruction are appropriate to the nature of what is to be learned and to the level of achievement desired.

Using the MCCleary and McIntyre model, instructional methodologies could be tailored to fit the competencies to be acquired by the learner. Factors that should be considered are whether the competencies or skills to be acquired were technical, human, or conceptual; and whether the level of proficiency to be acquired were familiarity, understanding, or application.

Dederick (1973) reported that the demand for competency-based programs to prepare educators was jrowing. To develop a program for the preparation of school administration he recommended that the 
following competencies be included: (1) initiating and responding to change, (2) decision making, (3) support for instructional and learning, (4) human relations and morale, (5) evaluatiny school processes and products, and (6) responding to problem situations.

Utilizing the perceptions of secondary-school principals in Indiana, McDavid (1973) found the following competencies to be valuable for beginning principals: (1) understanding of teaching/learning process, (2) ability to build and maintain student morale, (3) ability to build and maintain staff morale, (4) ability to effectively communicate with parents and community, (5) comprehension of general school-finance problems, (6) decision-making skills, and (7) curriculum and instruction.

in his study of the components of administrative competencies, wilbur (1973) found that important competencies which principals periorm were concerned with: (1) organizing and budgeting time commitments, (2) selecting, supervising and evaluating staff members, (3) utilizing others by delegating authority to individuals or groups, and (4) relieving the fears and doubts of those served or relieving conflict tensions betweer groups. Important competencies which principals coordinate were concerned with: (i) planning and establishing instructional goals and curriculum, (2) managing change in the school's operation by increasing student, staff, and community participation in decision making, (3) interpreting the school's program to the community, (4) adapting the school's program to a changing society while protecting the rights of all students, staff ar:d parents in their dealings with the school, and (5) evaluating the curricuium and assessing the programs designed to help students and teachers reach their potential. 
Weinnacht (1974) studied the competencies of high-school principals in the major urban areas of florida. His data were collected through personal interviews with fifteen high-school principals. He found that all of the principals were concerned about their dealings with people--identified as human relations, communications and school-community relations, and dealing with people from different racial and cultural backgrounds. They also emphasized the importance of staffing, student relationships, and curriculum and instruction as functions of the principals.

- From the perceptions of superintendents, principals, teachers, and college professors in the state of Texas, Austin (1973) identified eight general competency areas for secondary school principals. They were: (1) organization and administration, (2) curriculum design and improvement, (3) the instructional process, (4) business and financial management, (5) student management, (6) personnel management, (7) facilities, equipment, and supplies, and (8) communication. Burgess and his associates (1975) investigated the leadersnip and management requirements of principalship functions for the use of those who are invoived in the preparation of principals through preservice and in-service programs. They concluded that principals need competencies in eight components of the administrative processes; planning, organization, coordinating, communicating, evaluating, controlling, changing, and stimulating.

Bhandahari (1976) asserted that the foliowing competencies were necessary for principalship functions:

1. Ensuring that the available resources, both human and material are adequate for the task ahead. 
2. Jeploying the academic and non-academic staff, delegating duties and responsibilities, and supervising their work.

3. Planning and organizing for the learning-teaching process including the co-curricula activities.

4. Establisning daily routine procedures.

5. Establishing and maintaining pupil discipline and providing guidance services.

j. Managing school funds and maintaining accounts.

7. Attending to routine office correspondence.

8. Maintaining human relationship within the school.

3. Establishing school-community relationship.

10. Executing governmental policies and directives. (p. 17)

Conley (1976) conducted a study to determine the competencies needed by beginning school principals in Northern Illinois. He utilized elementary-school principals, middle or junior high-school principals, high-schcol principals, and superintendents as his respondents. His instrument was deyeloped from the research of McCleary in Utan, project R.O.M.E. in Georgia, ana Cook and Van Otten in Colorado and utan. iwenty-four of the twenty-seven competency statements he used were identified as needed by the beginning school principals at either the understanding or application levels of proficiency. Internship, pre-service, and workshop were indicated as effective procedures for developing many of the competencies.

McIntyre developed a set of thirty-two instructional leadership competency statements. Zechman (1977) utilized these statements to identify which instructional leadership conipetencies were expected of the secondary-school principal in the school districts of 
Pennsyliania. in prioritizing the thirty-two competency statements, the respondents (superintendents, principals, and teacners) chose the Foliowing as most critical: (1) assisting in the recruitment and selection of personnei for instructional responsibilities. (2) defining goals ard objectives, (3) collecting, organizing, analyzing, and interpreting data concerning the performance of teachers, (4) assigning or re-assigning instructional staff to optimize conditions for learning, (5) relating needs of students to school-system goals and iegal requirements, (6) recommending staff members for re-employment, promotion, or dismissal, (7) articulating goals and objectives for sub-units within the school, (8) establishing communcations with the schoo! constituency for the purpose of assessing needs and setting broad instructional goals, (9) communicating to the professional staff the feelings and desires of the school constituency and (10) allocating time and space to various instructionai purposes.

Burninam (1978) used superintendents, scnool-board presidents, and high-school principals as subjects in his study to determine the importance of the functions of high-school principals in the areas of curriculum and instructional leadership, personnel guidance, schoolcommunity relations, administrative responsibility, evaluation responsibility, and professional improvement. The three groups ranked evaluation responsibility and personnel guidance as first and second, respectiveiy. The ranking of the remaining four categories differed among the three groups, but the groups' combined responses ranked them as foilows: administrative responsibility, professinnal improvement, curriculum and instructional leadership, and school-community relations. 
-jons (1978) utilized the competency-based curriculum model that was prepared by MCCleary and icintyre in 1972 to determine the competencies needed by beginning secondary school principals in North Carolina. He used both superintendents and principals as nis respondents. The respondents were requested to indicate on a four-point, Likert-type scale (1) the essentiality of forty-three competencies for Jeginning principals, and (2) the preferred time each of the competencies snould be acquired--pre-service course work, internship, or through experience on the job. The respondents indicated that all forty-tnree competencies listed in the questionnaire were important skills for beginning school principals, although some were more essentidi than otiners. They suggested that thirty-five of the forty-three competencies listed should be acquired at the application level of proficiency, eight at the understanding level, and one at the familiarity levei.

The second research question in Lyons' study pertained to the procedure for acquiring the needed competencies. The respondents reported that thirt;-vite of the competencies should be acquired through experience in the position, three during the internship, and ten during the pre-service course work.

Grant (1978) conducted a study to ascertain and analyze the relationships that existed among perceptions of senior high-school principals, their teachers, and their superintendents regarding the importance of certain key areas of instrutional responsibility of the principals, and the degree of competency with which the principals performed their responsibilities. Grant's referent groups were 
randomly chosen irom a population located within one nundred miles of Sorpus Cinristi, Texas. The instrument used to determine the perceptions was derived from a list of thirty-two competency statements developed by AcIntyre. The competency statements were divided into eight areas of key responsibility of high-school principals. They were: (1) goal setting, (2) staffing, (3) allocating time and space, (4) allocating materials and equipment, (5) non-instructional services, (6) community relations, (7) in-service training, and (8) program evaluation. The thirty-two statements were listed on two survey instruments. The respondents were requested to make va? lie judgments on a weighted scale for each of the two instruments. To estimate the significance of differences, two-way analysis of variance procedures were used. The results of Grant's study indicated that there was a nigh correlation between the perceptions of the teachers on the priority of the eight areas of responsibilities and their evaluation of the performance of the principals. The principals were perceived as performing best in those areas considered most important by the teachers and performing lowest in those areas considered least important. The areas ranked in the top four for both priority and performance by all three groups were: (1) staffing, (2) community relations, (3) time and space, and (4) goal secting.

The UNESCO Report (1979) of the Regional Seminar held in Thailand centered on the alternative approaches in the preparation of educational personnel for education in Asia and Oceaniz. The problems discussed centered around the strategies used by teacher education institutions on the one hand and by schools on the other 
:o implement the oroad curriculum goals set up by the linistry of Education. Affiliations were required to ensure that teacher educaiion institutions do not remain isolated from the real situation of the scnools and the communities served. It was recognized that in order for the educational system to contribute to rural development, educational personnel needed to be trained in the competency of interpersonal relationships with the community and its members and in competencies related to work as a change agent witnin the tolerance limits of the political, social, and cultural environment of the population.

Hansen (1980) asserted that instructional leadersnip should include the ability to identify the in-service needs of teachers. Geering (1980) utilized central office staff, principals, and teachers in the Independent School District 196, Rosemount, Minnesota, as his respondents. He identified three competency areas that should be included in an in-service education program for principals of the district: scnool-comminity relations, student counseling and guidance, and research and development techniques.

One of the most critical challenges facing society today is the need to strengtinen the ethical standards of the youth. Violent crime and juvenile delinquency have been ascending. The role of the schools in this area is becoming cruciai. Cannon (1981) suggested that schools should strengthen and expand programs encouraging broad

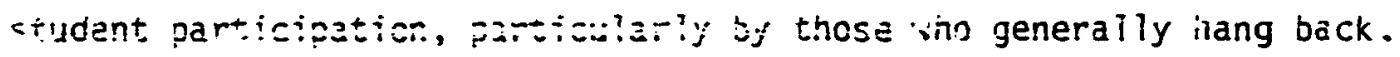
thereby providing more students with a sense of personal success. His suggestions imply that principais must possess competency in this ethical area. 
irump (1981) wrote a paper indicating that the principal

snould be competent in the area of instructional leadersinip. In zadition to maintaining the operation of the school building, he/she snould foster and exercise his/her role as an instructional leader.

\section{Professional Preparation of Principals}

From his review of literature focused on the effectiveness of senior high-schoc! principals: Hemphill (1965) found no single set of qualities of leadership that could be identified with successful principals. He noted, nowever, that successful principals overwhelmingly support internship as the most effective way to improve competencies required for administrative functions.

According to Farquhar and Martin (19i2), the predominant tendency in the program contents for administrative preparation since the mid-fifties has been away from techniques-oriented subjects based upon practical experience to a theory-based approach drawn from social disciplines such as sociclogy, social psychology, economics, political science, and anthropology. The school administrator has come to be viswed as an applied social scientist whose decision-making and problem-solving behavior can be more intelligently informed by theoretical insigrts than by procedurai "cookbooks".

Rasmussen and Hughes (1972) suggested the use of simulation to acquire competencies. According to them the use of simulation techniques could aid students of educational administration to "operationalize theory." The simulation activities could take place during the formal university courses or at seminars during the internship period. 
'Jsing pudiic secondary-school principals as his respondents IcDavid (1973) Found that the most valuable background or administraSive experience for a person preparing to become a secondary-school principal was to be an intern as an assistant principal or dean. :AcCabe and Compton (1974) noted that informal modes of learning administrative roles and competencies were more important than Formal modes. fccording to them there were four informal methods that emphasized the development of skills: Modeling superordinates, performing administrative-like duties, becoming certified, and learning on the job.

Cunningham (1974) stated that the preparation of principals required three important components: (1) knowledge/theory, (2) exper ience, and (3) a disciplined knowledge of self. The omission of any of the components could render the person ineffective.

Slate (1975) recommended that students should undergo an internship experience after the completion of the course work in educational leadership. Recognizing that certain competencies could je acquired on the job, he recommended an on-going training program For school administrators. The program should include visiting other school systems to observe grouping practices, teaching methods, and jupil-reporting techniques.

in a 1977 paper, Reed made several comments based on his review of related literature and observations. Among the observations were: (1) principals were critical of the lack of field orientation in most training programs and (2) internships were consiciered to be the most useful training for principals. 
walters (1979) utilized sixty-five principals from schooi districts in Pennsylvania and New York to rate a list of thirty-nine aaministrative competencies. The respondents rated the importance of each competency statement, stated the time when the competencies were acquired, and indicated the degree to which their own preparation programs had helped in acquiring the competency. 'Nalter's study indicated that ail but five competencies were acquired primarily on the job. The five competencies cited as seing acquired primarily before entry were tasks in the area of curriculum and instruction. Most principals reported that their own academic preparation programs had been of some assistance in acquiring the competencies.

According to Chaffee and Sioan (1980), an effective program preparing school administrators should include: (1) knowing what, (2) knowing how, and (3) having the opportunity to develop skills that practicing professional were required to perform. Competency development opportunities could be in the form of field experience, internships, simulation, and role playing.

Arizona State University conducted a two-year study to determine the scrool-community competencies for principals (Paddock, 1981). The project had two major objectives: (1) to identify school-community competencies and (2) to generate ideas about how competenices might be acquired. The study found twelve competencies rated as top in importance. The principals indicated that six of the tweive competencies should be acquired on the job. These were: (1) role or responsibility clarification, (2) generating staff support, (3) serve as liaison, 
if) neeas assessment supervision, (j) staif recruitment/selection, and (ó) Facility use planning/supervision. Those acquired through in-service were: (1) program evaluation, (2) policy and goal implementation, and (3) needs assessment supervision. Conflict management and curriculum planning/supervision ought to be acquired through preservice training.

\section{Educational System in Sabah}

iistorical background

The nistorical background of the educational system in Sabah is similar to that of other former colonial states in Malaysia. Two distinct factors have contributed to the development of the present educational systems: the English educational system during the colonial periods and the system of education in Malaya after the formation of Malaysia (Wong \& Ee, 1971).

During the colonial period the Christian missionaries took the lead in establishing schools, usually wherever a large cnurch congregation was organized. By the start of the twentieth century, English-language mission schoois had been established in nine towns of Sabah (Vreeland et al., 1977).

The annual report (1977) of the Department of Education of Sabah indicated that the first government school was estailished in 1915 at Jesselton (now Kota Kinabalu). The main objective of the school was to train the sons of native chiefs for government positions.

Even from the turn of the twentieth century, the government has recognized the roles played by the various church organizations 
in the development of education in Sabah. Some financial aid was given to scnools operated by these agencies. 3y 1917 there were inenty-three mission schools receiving partial government aid (Department of Education of Sabah, 1977).

In july 15, 1946, Saban became a Britisn Crown Colony. It was then calied the British North Borneo. The first Director of Education was appointed, and a five-year educational development plan was drawn to cover the period 1947-1952. Very little information is available regarding the educational policy of the department of education during this period. However, the 1977 annual report of the Jepartment of Education gives the following information about the colonial plan:

Within the framework of this $n$ ! Z?, provision was made for a new education policy which dimed to work towards 6 years of primary education for all and the elimination of illiteracy. Health education and igriculture mere to be stressed in particular. . . . Much importance was fiaced on the need to increase secondary education and provide a source of trained teachers for the colony's schools. (p. j)

With the formation of Malaysia on September 16, 1963, the Sabah Education Department became part of the Federal Ministry of Education. From this date the Director of Education became directly responsible to the Ministry of Education in Kuala Lumpur, the nation's capital. Since then there has been a rapid move to integrate the Sabah educational system with that of West Malaysia. The Department of Education of Sabah (1977) further states that the educational policy is:

a. To provide a free place in school for every child of primary school age. 
o. To extend facilities ior secondary education especially in rural areas.

c. To improve the quality of education in primary and secondary scnools.

a. To develop tecnnical and vocational training.

2. To extend facilities for teacher-training in order to cope with the rapid expansion envisaged in the primary and secondary enroliments.

$\approx$ To introduce Banasa Malaysia as the main medium of instruction. (p. 6)

The Malaysia Act of 1963 made a provision for Sabah to continue using English as the official language for a period of ten years (Milne \& Ratnan, 1974).

On December 1969, the Sabah Government announced that as of January 1970, primary schools in Sabah using English as the medium of instruction were to switch to Bahasa Malaysia (Sabah Times, 1970). The English language, nowever, would remain as a compulsory subject in the curriculum.

The demanc for education in Sabah has increased over the jears (see table 1). To meet this challenge the basic educational objectives cited earlier were reiterated in the Fourth Malaysia Plan-including: (1) to strengthen the unity of the people within the nation through the educational system and (2) to improve the quality of teacning and learning environment in the area of science and technology (Department of Education, 1980). The Fourth Malaysia Plan covers the period from 1981 to 1985 (Sabah State Government, 1980).

\section{The structure of educational system}

The basic structure of the educational system in Malaysia is presented in figure 1. A majority of the children begin their formal 
TABLE 1

STUDENT ENROLLLENT

\begin{tabular}{lcc}
\hline Year & Primary School Enrollment & Secondary School Enrollment \\
\hline 1960 & 46,957 & 3,806 \\
1970 & 110,607 & 30,603 \\
1980 & 141,292 & 03,085 \\
\hline
\end{tabular}

education of primary school at the age of six. The primary education continues through six grades. Students desiring further education after primary school can seek entrance to lower secondary schools. The lower secondary education consists of three years, forms 1 through 3, at the end of which students take an examination to qualify for a Lower Certificate of Education. Students who pass the examinasion can continue their general academic education in two years of upper secondaiy school, forms 4 and 5 . Among those who qualify for the Lower Certificate, a small number may take an option to enter into a combined program of general academic and technical training in agriculture and commerce (Vreeland et al., 1977).

- In form 5, students take the Malaysian Certificate Examinations. Some of the students who pass tile examina bivir =:tiet a vrie-iu three-year program in a college offering technical education or teacher training. A small proportion go on to pre-university training in form 6, a two-year academic program consisting of lower form 6 
and upper form 6 . The upper form 6 students are eligible to sit for the figher scnool Certificate examinations, and those who can pass are aligible to enter university (Vreeland et al., 1977).

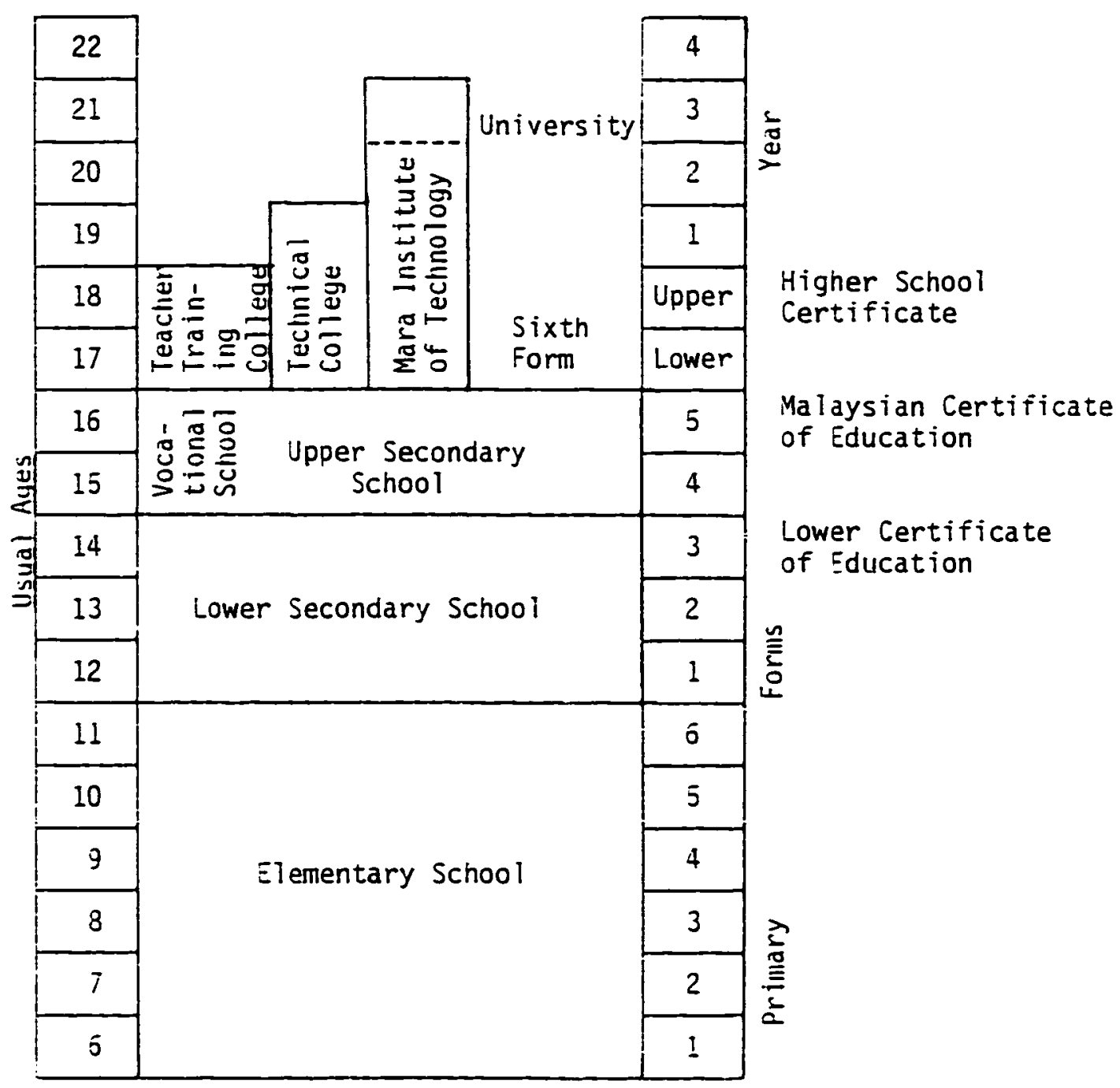

Figure 1: Basic structure of the educational structure in Malaysia The administration of education

The overall responsibility for the administration of schools in Malaysia lies with the Ministry of Education. As mentioned above, 
at the cime of the Federation of Malaysia in 1963 the Sabah Education Department became part of the Federal Ministry of Education. HenceForth, the Director of Education of Sabah is directly responsible to the Federai Ministry of Education in Kuala Lumpur, the nation's capital (Department of Education or Saban, 1977).

The department is administered by a central office and a regional office staff. According to the organizational chart prepared by Jamali Kassen (1981), there are six educational regions in Sabah. Each of these regions is under an education officer with a staff of school supervisors for language, science, and mathematics (Department of Education of Sabah, 1977).

The responsibility of reporting on all aspects of school administration and management to and from the Director of Education and the Malaysian Chief Inspector lies with the Regional Chief Inspector. The inspectorial group also advises principals on how to implement educational policies (Department of Education, 1977).

\section{Summary}

The review of the literature indicated that competency-based movements were growing in the training of school administrators. The i iterature further indicated that basic to the success of any competency-based program was the identification of the competencies required for a particular position.

Generally, the literature reviewed indicated that increasing attention nad been focused on the characteristics or competencies of principals. Some competencies were described in functionai terms and others in Dehavioral terms. For example, some articles listed 
competencies as job iunction--planning, preparing budgets, and evaluating personnel. Other articles presented a principal's competencies in terms of personal skills such as ability to lead, to communicate, or to delegate. In this study an attempt was undertaken to investigate principals' competencies in terms of personal skills.

i common thread found in the literature was the recognition that competencies needed for principalship must be identified for establishing the pre-service and in-service training needs of prinsipals, and for developing a program for students in educational administration.

Methods used in the professional preparation of school principals had taken the forms of internship, simulation, problem solving, and visitation. There appeared, however, a growing consensus that internship and in-service training were more effective than preservice course work taken in preparing principals for their job.

A review of the history of education in Sabah revealed that there were two factors that nad influenced the development of its educational system--the English educational system and the system of education in Malaya (West Malaysia). The administration of education is a centralized type with the director of education as the head. The educational work is expanding and the administration is becoming more complicated. Such growth demands more competencies on the part of the principals.

The review of the literature provided sufficient information for developing the instrument utilized in conducting this research. Chapter III presents the detailed procedure. 


\section{CHAPTER III}

\section{METHODOLOGY}

is nas been stated, the purpose of this study was to determine the competencies needed for principalship functions in Sabah. The description of the subjects, instrument, procedure, and analys is of the data are described in this chapter.

\section{Subjects of the Study}

Commenting on the determination of competency, McCleary and Mcintyre (1972) pointed out that the "identification of competencies must include the participation of practising school administrators if they are to be relevant and properly analyzed into their component jarts" (p. 56).

it was assumed in this study that the administrative staff of ine Department of Education, school inspectors, and principals are the Dest qualified persons available to identify the competencies for the performance of the duties of secondary-scnool principais in Sabah. They constitute the practising school administrators advocated by McCleary and McIntyre.

The annual statistical report of the Department of Education of Sabah provided the necessary information regarding the subjects for this study. The statistics indicated that the Department of Education nad twenty-three schonl inspectors, eighty-eight secondary-school 
principals, anc forty-eignt central orfice administrative personnel in :981. For tnis stucy the total population of eacn of the above categories was usea.

\section{Instrumentation}

The instrument utilized to generate the data was a modified questionnaire based on the research by Cook and Van Otten, 1972. They designed the instrument for the purpose of identifying some of the prime competencies required to perform the tasks of secondary school principalsnip in the states of Utah and Colorado. The competency statements were carefully developed by a panel of professors, graduate students, superintendents, and secondary-scnool principals. Subsequent researchers have used this questionnaire. Conley (1976) and Lyon (1979) modified and utilized the questionnaire to generate the data for their research.

$A$ panel of eignt judges was chosen to participate in the validation of the competency statements. The judges are Sabah educators who were studying in the United States in 1981. Their names are listed in appendix A. Prior to coming to the United States two of them had served as education officers, two as supervisors, three as principals, and one as a lecturer in a teacher's college. The survey questionnaire was mailed to each panel member for validation. They were requested to evaluate each competency statement in terms of its relevancy for inclusion in the survey instrument. A space was provided at the end of each category of competencies for the panel members to suggest additional items to be included on the final instrument (see appendix $B$ ). 
The majority of the responses of the judges indicated that eacn of the competency statements was relevant.

In the final draft oi the inscrument the competency statements were rated on a four-point Likert-type scale on the basis of their essentiality for principalship functions in Saban. A column based on Conley's research was added to determine the perceptions of the respondents regarding the most appropriate time for developing the competencies (see appendix C).

For further refinement and clarity of words, the instrument was pilot-tested utilizing ten Sabah teachers and frincipals who were studying in the United States in 1981. No significant difficulty was encounterea by the respondents in completing the questionnaire.

\section{Collection of Data}

The respondents for this study included the principals, school inspectors, and central office personnel in Sabah. Questionnaires were mailed directly to the principals, school inspectors, and regional officers on November 25, 1981. Questionnaires for the central office administrative personnel were mailed to $\mathrm{Mr}$. Herbert Gaban, a departmental education officar who assisted in distributing them personalis to the respondents. The respondents all work in the same building. A cover letter (see appendix $D$ ) and a self-addressed envelope were enclosed with the instrument. AlI respondents were instructed to return the questionnaire to Mr. Gaban who, in turn, forwarded them to the researcher.

Approximately six weeks after the initial mailing, a followup letter was sent to respondents who had not turned in their 
questionnaires. inese procedures resulted in a return of 116 questionnaires, or 72 percent (see table 2).

TABLE 2

RATE OF RETIJRN OF QUESTIONNAIRES

\begin{tabular}{lccc}
\hline \hline $\begin{array}{l}\text { Position of } \\
\text { Respondents }\end{array}$ & $\begin{array}{l}\text { Number } \\
\text { Mailed }\end{array}$ & $\begin{array}{c}\text { Number } \\
\text { Returned }\end{array}$ & $\begin{array}{c}\text { Percentage } \\
\text { of Return }\end{array}$ \\
\hline Central office & 48 & 37 & 77 \\
Inspectors & 23 & 18 & 78 \\
Principals & 38 & 61 & 68 \\
\hline \multicolumn{1}{c}{ iotals } & 159 & 116 & 72 \\
\hline
\end{tabular}

Ina?ysis of Data

The first step in the analytical procedure was the tabulation of the data into simple frequency distributions by category. This was used for determining the means for all of the competency statements, and as a basis for determining the mode score of the procedure for acquiring them.

The Chi-square analysis was ijext to determine if there were a significant difference between the way the three respondent groups rated the competencies and the procedures for acquiring them. A fourpoint Likert-type scale was used to indicate the degree to which the respondents perceived the importance of each competency statement. The values assigned on the scale were: $4=$ very important; $3=$ moderately important; 2 = fairly important; 1 = not important. Significance 
For ine rejection of the null hypotheses in this study was set at the .05 level of probability.

Kendali's concordance method was utilized to determine the degree of correlation between the ranking of the respondent groups on the administrative task areas on the basis of their importance.

This chapter describes the procedures used in collecting and analyzing the data. The tabulation and detailed analysis of the data are reported in chapter IV. 
CHAPTER IV

\section{PRESENTATION OF FINDINGS}

While this study was primarily to determine the necessary competencies required for secondary school principalship in Sabah, the treatment of this probiem included the investigation of three subpurposes:

1. To investigate studies undertaken in the aroa of administrative competencies, and attempt to do a similar investigation in Sabah.

2. To determine when the respondents perceive the most feasible time for developing these competencies; during the pre-service, in-service, or through experience on the job.

3. To determine how the respondent groups differ in their perceptions of the importance of the compeiencies, and the procedure by which they are to be acquired.

The findings relevant to these research questions are presented in this chapter. The responses of the principals, inspectors, and central office personnel were tabulated into simple frequency distributions for descriptive purposes. The responses to all the competency statements are presented in appendix $E$. The raw data shown in each table indicate now the respondents answered each competency statement. Chi-square analysis was used in this study to investigate whether the respondent groups differed significantly in the proportions 
of responses they assigned to indicate the importance of each compeiency statement and the procedure for acquiring it.

In the computation of the chi-square, the obseryed frequencies on the ratings "not important" and "fairly important" pertaining to the essentiality of the competencies were combined. This was done to ensure that at least eighty percent of the cells had expected frequencies of equal to five or more. Runyon and Haber (1975) suggested that when the degree of ireedom is greater than one then the expected frequency in eighty percent of the cells should equal or exceed five. The same method was taken with the observed frequencies relating to the procedure for acquiring the competencies. In the computation of the chi-square of the essentiality of competencies, four degrees of ireedom indicate that two cellis were combined. In the computation of the chi-square on the procedure for acquiring the competencies, two degrees of freedom indicate that two cells were combined.

To guide in the interpretation of the weighted mean score for each competency statement and the distribution of responses on the orocedure for acquiring the competency, the following arbitrary rules were set up: A mean score between 3.50 and 4.00 was considered as very important; 2.50 to 3.49 as moderately important; and 1.50 to 2.49 as fairly important. The procedure that had the highest percentage of frequencies was considered as the most appropriate means for acquiring the competency. However, due to the nature of the distribution of the observed frequencies, the procedures which had frequency percentage that were within twenty percent from the highest were also considered as appropriate means for acauiring the competency. 
in the presentation of the results of this study, the analysis of the data on the essentiality of the competencies, the procedure for acquiring inem, and the differences and similarities of the perceptions of the respondents were presented simultaneously.

\section{Analysis of Competency Statements}

The research questionnaire comprised twelve administrative cask areas and the competency statementz were subsumed under each of these areas. The twelve aministrative task areas are:

1. Policy development

2. Business affairs: budget, accounting, purcnasing

3. Community services and community relations

4. Pupil personnel services: guidance, counseling services

इ. Student activities, including sports and music

6. Pupil control: discipline and attendance

7. Building-level organization and control, and school plant

3. Auxiliary services: cafeteria, health, and safety

9. Staff personnel: assignment, working conditions, certification, and classification

10. Staif improvement: evaluation, in-service training, involvement in policy development

11. Program evaluation and planning, curriculum development, instruction

12. Research and development projects, investigation and testing of new techniques, innovations and change.

\section{Policy development}

The first administrative task area dealt with policy development with three competencies subsumed under it. The data in table 3 
TABLE 3

RESPONSES TO ADMINISTRATIVE TASK AREA

POLICY DEVELOPMENT

\begin{tabular}{|c|c|c|c|c|c|}
\hline Competency & Respondents & Essentiality & $x^{2}$ & Procedure & $x^{2}$ \\
\hline \multirow{3}{*}{1} & Principals & $\begin{array}{l}\text { Very } \\
\text { important }\end{array}$ & \multirow{3}{*}{$\begin{array}{l}2.192 \\
d f=4\end{array}$} & $\begin{array}{l}\text { In-service } \\
\text { Experience }\end{array}$ & \multirow{3}{*}{$\begin{array}{l}6.012 \\
d f=4\end{array}$} \\
\hline & Inspectors & $\begin{array}{l}\text { Very } \\
\text { important }\end{array}$ & & In-service & \\
\hline & $\begin{array}{l}\text { Office } \\
\text { personnel }\end{array}$ & $\begin{array}{l}\text { Moderately } \\
\text { important }\end{array}$ & & $\begin{array}{l}\text { In-service } \\
\text { Experience }\end{array}$ & \\
\hline \multirow{3}{*}{2} & Principais & $\begin{array}{l}\text { Moderately } \\
\text { important }\end{array}$ & \multirow{3}{*}{$\begin{array}{l}2.160 \\
d f=4\end{array}$} & $\begin{array}{l}\text { In-service } \\
\text { Experience }\end{array}$ & \multirow{3}{*}{$\begin{array}{l}1.939 \\
d f=2\end{array}$} \\
\hline & Inspectors & $\begin{array}{l}\text { Moderately } \\
\text { important }\end{array}$ & & Experience & \\
\hline & $\begin{array}{l}\text { Office } \\
\text { personnel }\end{array}$ & $\begin{array}{l}\text { Moderately } \\
\text { important }\end{array}$ & & $\begin{array}{l}\text { In-service } \\
\text { Experience }\end{array}$ & \\
\hline \multirow{3}{*}{3} & Principals & $\begin{array}{l}\text { Moderately } \\
\text { important }\end{array}$ & \multirow{3}{*}{$\begin{array}{l}3.411 \\
d f=4\end{array}$} & $\begin{array}{l}\text { In-service } \\
\text { Experience }\end{array}$ & \multirow{3}{*}{$\begin{array}{l}0.096 \\
\text { df }=2\end{array}$} \\
\hline & Inspectors & $\begin{array}{l}\text { Moderately } \\
\text { important }\end{array}$ & & Experience & \\
\hline & $\begin{array}{l}\text { Office } \\
\text { personnel }\end{array}$ & $\begin{array}{l}\text { Moderately } \\
\text { important }\end{array}$ & & $\begin{array}{l}\text { In-service } \\
\text { Experience }\end{array}$ & \\
\hline
\end{tabular}

indicate the perceptions of the principals, inspectors, and central jifice administrative personnel regarding the competencies related to pol icy deveiopment.

Competency 1 (work with the school board, school inspectors, supervisors, and staff personinel in the estabiishment, coordination, 
and interpretation and enforcement of educational policies) was persaived oy the principals and school inspectors as very important. Hithough the central office personnel perceived this competency as only moderately important, tne differences were not significant. With a mean score of 3.51 the groups as a whole perceived this competency as very important. The mean score for every competency is found in the tables in appendix $E$. The inspectors perceived that this competency could be acquired through in-service programs, but the principals and central office personnel considered both in-service and experience on the job as necessary procedures. The difference, however, was not significant. As a whole, in-service programs and experience on the job were perceived as the most appropriate means.

Competency 2 (consult with Department of Education personnel on educational and organization matters) received a mean score of 3.25 from all the respondents wich indicates that the groups perceived this competency as moderately important. The inspectors viewed experience on the job as the best means for acquiring this competency, while the principals and central office personnel perceived both inservice and experience on the job as the best means. As indicated by the chi-square value, the differences between the perceptions of the yroups on the essentiality and procedure for acquiring this competency were not significant. As a whole, in-service and experience on the job were perceived as the most feasible means for acquiring the competency.

Competency 3 (serve as liaison between the school, the district, and the state) was perceived by all three groups as moderateily 
imoortant with a mean score of 2.93. The inspectors perceived experience on the job as the ideal means for acquiring this competency while the principals and central office personnel perceived both in-service and experience on the job as necessary. The differences were shown to se not significant. As a whole the respondents perceived in-service programs and experience on the job as the ideal means for developing this competency.

Summary

Two of the competencies (2 and 3) related to policy development were perceivec by the respondenis as moderately important, and competency 1 was perceived as very important. In-service programs and experience on the job were considered as the best means for developing all the three competencies.

Business affairs: budgetina, accounting purchasing

The competency statements in the area of business affairs were listed as competency 4,5 , and 6 . The data presented in table 4 indicate the perceptions of the principals, inspectors, anci central office personnel concerning the competencies related to business affairs. Competency 4 (organize, supervise, and manage the business affairs of the school) was perceived by the inspectors and central office personnel as moderately important. Although the principais perceived it to be very important, the differences in their perceptions were shown to be not significant. The perceptions of the respondents as a whole leaned toward very important with a mean score of 3.50. The perceptions of the three groups differed significantly on 
TABLE 4

RESPONSES TO ADMINISTRATIVE TASK AREA

SUSINESS AFFAIRS

\begin{tabular}{|c|c|c|c|c|c|}
\hline Competency & Respondents & Essentidity & $x^{2}$ & Procedure & $x^{2}$ \\
\hline \multirow{3}{*}{4} & Principals & $\begin{array}{l}\text { Very } \\
\text { important }\end{array}$ & \multirow{3}{*}{$\begin{array}{r}2.513 \\
d f=4\end{array}$} & $\begin{array}{l}\text { Pre-service } \\
\text { In-service }\end{array}$ & \multirow{3}{*}{$\begin{array}{l}22.473 t \\
d f=4\end{array}$} \\
\hline & Inpsectors & $\begin{array}{l}\text { Moderately } \\
\text { important }\end{array}$ & & Pre-service & \\
\hline & $\begin{array}{l}\text { Office } \\
\text { personnel }\end{array}$ & $\begin{array}{l}\text { Moderately } \\
\text { important }\end{array}$ & & In-service & \\
\hline \multirow{3}{*}{5} & Principals & $\begin{array}{l}\text { Moderately } \\
\text { important }\end{array}$ & \multirow{3}{*}{$\begin{array}{l}7.895 \\
d f=4\end{array}$} & In-service & \multirow{3}{*}{$\begin{array}{r}4.956 \\
d f=2\end{array}$} \\
\hline & Inspectors & $\begin{array}{l}\text { Moderately } \\
\text { important }\end{array}$ & & Experience & \\
\hline & $\begin{array}{l}\text { Office } \\
\text { personnel }\end{array}$ & $\begin{array}{l}\text { Moderately } \\
\text { important }\end{array}$ & & $\begin{array}{l}\text { In-service } \\
\text { Experience }\end{array}$ & \\
\hline \multirow{3}{*}{6} & Principals & $\begin{array}{l}\text { Moderately } \\
\text { important }\end{array}$ & \multirow{3}{*}{$\begin{array}{l}2.558 \\
d f=4\end{array}$} & $\begin{array}{l}\text { In-service } \\
\text { Experience }\end{array}$ & \multirow{3}{*}{$\begin{array}{l}2.751 \\
d f=2\end{array}$} \\
\hline & Inspectors & $\begin{array}{l}\text { Moderately } \\
\text { important }\end{array}$ & & Experience & \\
\hline & $\begin{array}{l}\text { Office } \\
\text { personnel }\end{array}$ & $\begin{array}{l}\text { Moderately } \\
\text { important }\end{array}$ & & $\begin{array}{l}\text { In-service } \\
\text { Experience }\end{array}$ & \\
\hline
\end{tabular}

*significant at 0.05 level

the procedure for acquiring this competency. The chi-square of 22.473 reflects this significance. The principals perceived both in-service and pre-service programs as the ideal means for developing this competency, while the inspectors perceived pre-service alone as sufficient. 
ine central office personnel perceived in-service programs as the best neans for acquiring the competency.

Competency 5 (make resources available to the staff: supplies, money, equipment, etc.) received a mean score of 3.02 indicating that the groups perceived this competency as moderately important. The principals perceived in-service programs as the best procedure for acquiring this competency, but the inspectors believed that the principals could acquire this competency through experience on the job. Uffice personnel on the other hand considered both in-service and experience on the job as necessary procedures. These differences, however, were not significant. As a whole the respondents perceived both in-service and experience on the job as the best means.

Competency 6 (utilize resources and money to provide for the educationai progran in his/her school) was perceived by all the groups as moderately important with a mean score of 3.35 . The principals and central office personnel perceived in-service programs and experience on the job as the most feasible means for developing this competency, while the majority of the inspectors considered experience on the job as sufficient. As refiected by the chi-square value, these differences were shown to be not significant. As a whole the perceptions of ali the groups leaned toward in-service and experience on the job as the best means.

Summary

Competencies 5 and 6 of the competencies related to business affairs were perceived by all the respondents as moderately important and could be acquired through in-service programs and experience on 
she joo. Competency 4 was perceived as very important, but tne groups differed significantly on the procedure for acquiring this competency.

Community services and community

relations

The four competencies in the area of community services and community relations are listad as competency $7,8,9$, and 10 . The data presented in table $j$ indicate how the principals, inspectors, and central office personnel perceived the essentiality of the competencies related to community services and community relations, and the procedures for acquiring them.

Competency 7 (establish a public relations program with the community--parents, teachers, and students) was perceived by the principals and inspectors as very important, ard the central office personnel as moderately important. The chi-square value indicates that the differences of the perceptions of the three groups ivere not significant. Their perceptions as a whole leaned toward moderately important rating. The respondent groups perceived in-service programs and experience on the job as the best means for developing this competency. There was no significant difference shown among the three respondent groups in their perceptions concerning the procedure for acquiring it.

Competency 8 (communicate with school patrons) which received a mean score of 2.62 was considered by all the respondent groups as moderately importarit. Respondents aiso feit that the acquisition of this competency could best be gained through experience on the job. No significant differences were indicated in the perceptions of the 
TABLE 5

RESPONSES TO ADMINISTRATIVE TASK AREA:

COMMUNITY SERVICES AND

COMMUNITY RELATIONS

\begin{tabular}{|c|c|c|c|c|c|}
\hline Competency & Respondents & Essentiality & $x^{2}$ & Procedure & $x^{2}$ \\
\hline \multirow{3}{*}{7} & Principals & $\begin{array}{l}\text { Yery } \\
\text { important }\end{array}$ & \multirow{3}{*}{$\begin{array}{l}4.747 \\
d f=4\end{array}$} & $\begin{array}{l}\text { In-service } \\
\text { Experience }\end{array}$ & \multirow{3}{*}{$\begin{array}{l}2.468 \\
d f=4\end{array}$} \\
\hline & Inspectors & $\begin{array}{l}\text { Very } \\
\text { important }\end{array}$ & & $\begin{array}{l}\text { Iri-service } \\
\text { Experience }\end{array}$ & \\
\hline & $\begin{array}{l}\text { Office } \\
\text { personnel }\end{array}$ & $\begin{array}{l}\text { Moderately } \\
\text { important }\end{array}$ & & $\begin{array}{l}\text { In-service } \\
\text { Experience }\end{array}$ & \\
\hline \multirow{3}{*}{3} & Principals & $\begin{array}{l}\text { Moderately } \\
\text { important }\end{array}$ & \multirow{3}{*}{$\begin{array}{l}0.580 \\
d f=4\end{array}$} & Experience & \multirow{3}{*}{$\begin{array}{l}2.468 \\
d f=2\end{array}$} \\
\hline & Inspectors & $\begin{array}{l}\text { Moderatel } \\
\text { importani }\end{array}$ & & Experience & \\
\hline & $\begin{array}{l}\text { Office } \\
\text { personnel }\end{array}$ & $\begin{array}{l}\text { Moderately } \\
\text { important }\end{array}$ & & Experience & \\
\hline \multirow{3}{*}{9} & Principals & $\begin{array}{l}\text { Moderateiy } \\
\text { important }\end{array}$ & \multirow{3}{*}{$\begin{array}{l}2.835 \\
d f=4\end{array}$} & Experience & \multirow{3}{*}{$\begin{array}{l}5.981 \\
d f=2\end{array}$} \\
\hline & Inspectors & $\begin{array}{l}\text { Moderately } \\
\text { important }\end{array}$ & & Experience & \\
\hline & $\begin{array}{l}\text { Office } \\
\text { personnel }\end{array}$ & $\begin{array}{l}\text { Moderately } \\
\text { important }\end{array}$ & & $\begin{array}{l}\text { In-service } \\
\text { Experience }\end{array}$ & \\
\hline \multirow{3}{*}{10} & Principals & $\begin{array}{l}\text { Moderately } \\
\text { important }\end{array}$ & \multirow{3}{*}{$\begin{array}{l}6.469 \\
d f=4\end{array}$} & Experience & \multirow{3}{*}{$\begin{array}{l}1.192 \\
d f=2\end{array}$} \\
\hline & Inspectors & $\begin{array}{l}\text { Moderately } \\
\text { important }\end{array}$ & & Experience & \\
\hline & $\begin{array}{l}\text { Office } \\
\text { personnel }\end{array}$ & $\begin{array}{l}\text { Moderately } \\
\text { important }\end{array}$ & & $\begin{array}{l}\text { In-service } \\
\text { Experience }\end{array}$ & \\
\hline
\end{tabular}


groups regaraing the essentiality of this competency and the procedure For acquiring it.

Competency 9 imediate disputes among parents, beachers, staff, and students) received $\exists$ mean score of 3.25 indicating that the three groups considered it as moderately important. No significant differences were snown among the groups in their perceptions regarding the essentiality of this competency and the procedure for acquiring it. As a wrole the three groups perceived experience on che job as tne best means for acquiring this competency, even though the principals saw that in-service programs could also be effective.

Competency 10 (identify the community forces which affect the operation of the school and the implementation of those forces) received a mean score of 3.15 which indicates that this competency was also considered as moderately important. The perceptions of the groups did not differ significantly on the essentiality of the competency and the procedure for acquiring it. As with the competencies within the task area, the respondents as a whole indicated that this competency could best be acquired through experience on the job, even though the central office personnel perceived that this competency could also be developed through in-service programs.

Summary

All four competencies related to community services and community relations were perceived as moderately important and could be acquired through experience on the jot. For competency 7 , an inservice program was also seen as an effective means. 
Pupil personnel services: quidance

and counseiing services

The competencies in the area of pupil personnel services are

listed as competency $11,12,13,14$, and 15 . The data in table 6 snow the perceptions of the principals, inspectors, and central office personnel concerning pupil personnel services.

Competency 11 (utilize counseling techniques and provide a guidance program for students), with a mean score of 3.34 , was considered by the three respondent groups as moderately important. The preferred procedure for acquiring it was through pre-service and inservice programs. Although the principals and inspectors perceived in-service programs as the most effective means for acquiring the competency, the perceptions of the groups as a wnole leaned more toward the utiitization of both means--pre-service and in-service. Competency 12 (encourage students to participate in developing and implementing student programs), which received a mean score of 3.31 , was seen by ali three groups as moderately important. Although the groups did not differ significantly in their perceptions of the essentiality of this competency, they did differ signifirantly regarding the procedure for acquiring it. This was reflected in the chi-square value of 13.13. Each group held different opinions regarding the acquisition of tnis competency. While the inspectors preferred its acquisition through experience on the job, the principals and central office administrative personnel felt that the most feajib?a maans should be through in-service programs. The principals perceived that this competency should diso be developed through experience on the job. 
TABLE Ó

RESPONSES TO ADMINISTRATIVE TASK AREA:

PUPIL PERSONINEL SERVICES

\begin{tabular}{|c|c|c|c|c|c|}
\hline Competency & Respondents & Essentiality & $x^{2}$ & Procedure & $x^{2}$ \\
\hline \multirow{3}{*}{11} & Principals & $\begin{array}{l}\text { Moderately } \\
\text { important }\end{array}$ & \multirow{3}{*}{$\begin{array}{l}5.872 \\
d f=4\end{array}$} & In-service & \multirow{3}{*}{$\begin{array}{l}1.46 ; \\
d f=4\end{array}$} \\
\hline & Inspectors & $\begin{array}{l}\text { Moderately } \\
\text { important }\end{array}$ & & In-service & \\
\hline & $\begin{array}{l}\text { Office } \\
\text { personnel }\end{array}$ & $\begin{array}{l}\text { Moderately } \\
\text { important }\end{array}$ & & $\begin{array}{l}\text { Pre-service } \\
\text { In-service }\end{array}$ & \\
\hline \multirow{3}{*}{12} & Principdls & $\begin{array}{l}\text { Moderately } \\
\text { important }\end{array}$ & \multirow{3}{*}{$\begin{array}{l}2.026 \\
d f=4\end{array}$} & $\begin{array}{l}\text { In-service } \\
\text { Experience }\end{array}$ & \multirow{3}{*}{$\begin{array}{l}13.131^{*} \\
d f=2\end{array}$} \\
\hline & Inspectors & $\begin{array}{l}\text { Moderately } \\
\text { important }\end{array}$ & & Experience & \\
\hline & $\begin{array}{l}\text { Office } \\
\text { personnel }\end{array}$ & $\begin{array}{l}\text { Moderately } \\
\text { important }\end{array}$ & & In-service & \\
\hline \multirow{3}{*}{ i3 } & Principals & $\begin{array}{l}\text { Moderately } \\
\text { important }\end{array}$ & \multirow{3}{*}{$\begin{array}{l}5.400 \\
d f=4\end{array}$} & $\begin{array}{l}\text { In-seivice } \\
\text { Experience }\end{array}$ & \multirow{3}{*}{$\begin{array}{l}5.913 \\
d f=2\end{array}$} \\
\hline & Inspectors & $\begin{array}{l}\text { Moderately } \\
\text { important }\end{array}$ & & Experience & \\
\hline & $\begin{array}{l}\text { Office } \\
\text { personnel }\end{array}$ & $\begin{array}{l}\text { Moderately } \\
\text { important }\end{array}$ & & Experience & \\
\hline \multirow{3}{*}{14} & Principals & $\begin{array}{l}\text { Moderately } \\
\text { important }\end{array}$ & \multirow{3}{*}{$\begin{array}{l}7.585 \\
d f=4\end{array}$} & Experience & \multirow{3}{*}{$\begin{array}{l}4.111 \\
d \tilde{d}=2\end{array}$} \\
\hline & Inspectors & $\begin{array}{l}\text { Moderately } \\
\text { important }\end{array}$ & & Experience & \\
\hline & $\begin{array}{l}\text { Office } \\
\text { personnel }\end{array}$ & $\begin{array}{l}\text { Moderately } \\
\text { important }\end{array}$ & & Experience & \\
\hline
\end{tabular}

*significant at 0.05 level 
TABLE Ó--Continued

\begin{tabular}{|c|c|c|c|c|c|}
\hline Competency & Respondents & Essentiality & $x^{2}$ & Procedure & $x^{2}$ \\
\hline \multirow{3}{*}{15} & Principals & $\begin{array}{l}\text { Moderately } \\
\text { important }\end{array}$ & \multirow{3}{*}{$\begin{array}{l}4.346 \\
d f=4\end{array}$} & Experience & \multirow{3}{*}{$\begin{array}{l}1.341 \\
d f=2\end{array}$} \\
\hline & Inspectors & $\begin{array}{l}\text { Moderately } \\
\text { important }\end{array}$ & & Experience & \\
\hline & $\begin{array}{l}\text { Office } \\
\text { personnel }\end{array}$ & $\begin{array}{l}\text { Moderately } \\
\text { important }\end{array}$ & & Experience & \\
\hline
\end{tabular}

Competency 13 (establish methods for reporting pupil programs) received a mean score of 3.16 . It was considered as moderately imporzant by all the respondent groups. Althougn each of the groups felt that the appropriate procedure for acquiring the competency was ihrough experience on the job, the principals perceived that in-service proyraiis culd also be effective. Is a whole the perceptions of the groups leaned more toward the utilization of both in-service and experience on the job as the best means for developing this comperency.

Competency 14 (advocate. speak for, the students when appropriate), with a mean score of 1.79 , was perceived as moderately important by all the respondent groups, and they felt that the acquisition of this competency was through experience on the job. No significant difference was shown among the groups in their perceptions of the essentiaity and procedure for acquiring this competency. Competency 15 (communicate with students concerning all aspects of their school life) received a mean score of 3.21 and was 
rewed is noderazely important py the three groups. As with the uther compezencies in chis sask area, the respondents felt that this sompetency could be acquired through experience on the job. Their serceptions on the essentiality of this competency and the procedure For acquiring it did not differ significantly.

Surmary

All the competencies related to pupil personnel services were perceived as moderately important. Experience on the job was considered the best means for acquiring competency 13,14, and 15, and in-service and pre-service course work for competency 11 . The groups differed significantly in their perceptions on the procedure for acquiring competency 12 .

Student artivities--including music and sports

The competencies related to student activities are listed as competency $16,17,18$, and 19 . The perceptions of the principals, inspectors, and central office personnel on these competencies are presented in table 7 .

Competency 16 (organize, coordinate, and administer the total activities program) was perceived by the three respondent groups as noderately important with a mean score of 3.21 . There was no significant difference in their perceptions of the essentiality of this competency. The groups, hawever, differed significantly in their perceptions regarding the procedure for acquiring this competency. This was reflected by the chi-square value of 11.04 . The central office personnel considered the acquisition of this competency through 
TABLE 7

RESPONSES TO ADMINISTRATIVE IASK AREA:

STLDENT ACTIVITIES

\begin{tabular}{|c|c|c|c|c|c|}
\hline Competency & Res pondents & Essentiality & $x^{2}$ & Procedure & $x^{2}$ \\
\hline \multirow{3}{*}{16} & Principals & $\begin{array}{l}\text { Moderately } \\
\text { important }\end{array}$ & \multirow{3}{*}{$\begin{array}{l}6.382 \\
d f=4\end{array}$} & $\begin{array}{l}\text { Pre-service } \\
\text { In-service }\end{array}$ & \multirow{3}{*}{$\begin{array}{l}11.038^{*} \\
d f=4\end{array}$} \\
\hline & Inspectors & $\begin{array}{l}\text { Moderately } \\
\text { important }\end{array}$ & & Pre-service & \\
\hline & $\begin{array}{l}\text { Office } \\
\text { personnel }\end{array}$ & $\begin{array}{l}\text { Moderately } \\
\text { important }\end{array}$ & & In-service & \\
\hline \multirow{3}{*}{17} & Principals & $\begin{array}{l}\text { Moderately } \\
\text { important }\end{array}$ & \multirow{3}{*}{$\begin{array}{l}5.747 \\
d f=4\end{array}$} & $\begin{array}{l}\text { Pre-service } \\
\text { In-service }\end{array}$ & \multirow{3}{*}{$\begin{array}{l}11.849 * \\
d f=4\end{array}$} \\
\hline & Inspectors & $\begin{array}{l}\text { Moderately } \\
\text { important }\end{array}$ & & $\begin{array}{l}\text { Pre-service } \\
\text { in-service } \\
\text { Experience }\end{array}$ & \\
\hline & $\begin{array}{l}\text { Office } \\
\text { Personnel }\end{array}$ & $\begin{array}{l}\text { Mode-ately } \\
\text { importan: }\end{array}$ & & In-service & \\
\hline \multirow{3}{*}{18} & Principals & $\begin{array}{l}\text { Moderately } \\
\text { important }\end{array}$ & \multirow{3}{*}{$\begin{array}{c}20.684 \\
d f=4\end{array}$} & In-service & \multirow{3}{*}{$\begin{array}{l}0.600 \\
d f=2\end{array}$} \\
\hline & Inspectors & $\begin{array}{l}\text { Moderately } \\
\text { important }\end{array}$ & & Experience & \\
\hline & $\begin{array}{l}\text { úffice } \\
\text { personnel }\end{array}$ & $\begin{array}{l}\text { Fairly } \\
\text { important }\end{array}$ & & $\begin{array}{l}\text { In-service } \\
\text { Experience }\end{array}$ & \\
\hline \multirow{3}{*}{19} & Principals & $\begin{array}{l}\text { Moderately } \\
\text { important }\end{array}$ & \multirow{3}{*}{$\begin{array}{l}4.496 \\
d i=4\end{array}$} & Experience & \multirow{3}{*}{$\begin{array}{l}4.484 \\
d f=2\end{array}$} \\
\hline & Inspectors & $\begin{array}{l}\text { Moderately } \\
\text { important }\end{array}$ & & Experience & \\
\hline & $\begin{array}{l}\text { Office } \\
\text { Personnel }\end{array}$ & $\begin{array}{l}\text { Moderately } \\
\text { important }\end{array}$ & & Experience & \\
\hline
\end{tabular}

*Significant at 0.05 level 
in-service srograms, wnile tne scnool inspectors viewed its acquisi:ion through pre-service course work. As for the principals, they indicated that joth in-service and pre-service programs were effecEive means for acquiring this competency.

Competency 17 (evaluate the student activities program) received a mean score of 3.07 and was perceived by the three groups as moderately important. Although no significant difference were indicated in their perceptions of the essentiality of this competency, their perceptions on the procedure for acquiring it did differ signiFicantly witi a cni-square value of 11.84. While the central office personnel felt that in-service programs would be the most feasible means for acquiring this competency, the principals saw that both pre-service and in-service were effective means. As for the inspectors, they perceived that all three procedures (pre-service, inservice, and experience on the job) could be effective.

Competency 18 (maintain participation standards for student activity program) was perceived by the principals and inspectors as moderately important, while the central office personnel saw it as fairly important. The differences in their perceptions were shown to be quite significant as reflected by the chi-square value of 20.684 . In the procedure for acquiring the competency, the principais and central office personnel saw in-service programs and experience on the job as the feasible means for acquiring it. The inspectors saw oniy experience on the job as the best means. As a whole the respondent groups perceived both in-service and experience on the job as the most feasible means for acquiring this competency. 
Eomoetency ig imaintain a program of spectator control at all scnool acsivities), with 3 mean score of 2.76 , was perceived by all the respondent groups as moderately important and should be acquired inrough experience on the job. The perceptions of the three groups on the essentiality of this competency and the procedure for acquiring it did not differ significantly.

Summary

ine perceptions of the groups differed significantly on the essentiality of competency 18, and on the procedure for acquiring competency 16 and 17 . The rest of the competencies were perceived as moderately important. Experience on the job was considered as the best means for acquiring competencies 18 and 19.

\section{Pupil control: discipline, attendance}

The competencies related to pupit control are listed as competency 21 and 22 . Table 8 indicates the perceptions of the principals, inspectors, and central office personnel on these competencies.

Competency 20 (establish attendance accounting procedures) was perceived by all the grcups as moderately important with a mean score of 3.39 . In the procedure for acquiring this competency, the orincipals and inspectors saw in-service and experience on the job as the best means for developing this competency. The central office personnel saw only in-service as the best means. As a whole the respondents considered only in-service as the best means. The groups did not differ significantly in their perceptions on the essentiality of this competency and the procedure for acquiring it. 
TABLE 3

RESPONSES TO ADMINISTRATIVE TASK AREA

PUPIL CONTROL

\begin{tabular}{|c|c|c|c|c|c|}
\hline Competency & Respondents & Essentiality & $x^{2}$ & Procedure & $x^{2}$ \\
\hline \multirow{3}{*}{20} & Principals & $\begin{array}{l}\text { Moderately } \\
\text { important }\end{array}$ & \multirow{3}{*}{$\begin{array}{l}6.965 \\
d f=4\end{array}$} & $\begin{array}{l}\text { In-service } \\
\text { Experience }\end{array}$ & \multirow{3}{*}{$\begin{array}{l}1.258 \\
d f=2\end{array}$} \\
\hline & Inspectors & $\begin{array}{l}\text { Moderately } \\
\text { important }\end{array}$ & & $\begin{array}{l}\text { Pre-service } \\
\text { Experience }\end{array}$ & \\
\hline & $\begin{array}{l}\text { Office } \\
\text { personnel }\end{array}$ & $\begin{array}{l}\text { Moderately } \\
\text { important }\end{array}$ & & In-service & \\
\hline \multirow{3}{*}{21} & Principals & $\begin{array}{l}\text { Very } \\
\text { important }\end{array}$ & \multirow{3}{*}{$\begin{array}{l}4.568 \\
d f=4\end{array}$} & Experience & \multirow{3}{*}{$\begin{array}{l}14.047^{\star} \\
d f=4\end{array}$} \\
\hline & Inspectors & $\begin{array}{l}\text { Moderately } \\
\text { important }\end{array}$ & & $\begin{array}{l}\text { Pre-service } \\
\text { Experience }\end{array}$ & \\
\hline & $\begin{array}{l}\text { Office } \\
\text { personnel }\end{array}$ & $\begin{array}{l}\text { Very } \\
\text { important }\end{array}$ & & $\begin{array}{l}\text { Pre-service } \\
\text { In-service } \\
\text { Experience }\end{array}$ & \\
\hline
\end{tabular}

*Significant at 0.05 level

Competency 21 (establish student control and disciplinary procedures with the assistance of parents, teachers, and students) received a mean score of 3.55 from all three groups. This indicates that the perceptions of the respondents as a whole leaned more toward very important. Although the groups did not differ significantly in their perceptions regarding the essentiality of this competency, they did show significant difference in their perceptions on the procedure for acquiring it, with a chi-square value of 14.047 . These differences were indicated as follows: The principals perceived experience 
on ine joo as the sest procedure cor acquiring the competency; the inspectors saw pre-service and experience on the job as the best means; and the central office personnel saw that all three procedures (pre-service, in-service, and experience) could be effective.

Sumnary

In the area of pupil control, the respondents perceived competency 20 as moderately important and competency 21 as very imporsant. They differed in their opinions regarding the procedure for acquiring competency 21 , but agreed that competency 20 could be acquired through in-service programs.

\section{Building-level organization} and control of school plant

The competencies related to building-level organization and control of scnool plant are listed as competency $22,23,24$, and 25. The data in taole 9 snow the perceptions of the principals, inspecsors, and central office personnel on the competencies related to this task area.

Competency 22 (organize and manage a school program which implements the school philosophy) received a mean score of 3.26 . All three groups considered this competency as moderately important. No significant difference was shown in their perceptions regarding the essentiality of this competency. In the procedure for acquiring this competency, the inspectors perceived that pre-service and in-service programs could be the best means, while the principals and central office personnel saw that all three methods (pre-service, in-service, and experience on the $j o b)$ could be effective means. The differences 
in their perceptions, nowever, were snown to be not sigrificant. As a wnole, the respondents saw all three netnods as effective means for 3cquiring the competency.

Competency 23 (schedule the school academic frogram) received a mean score of 3.41. Even though this competency was perceived by

TABLE 9

RESPONSES TO ADMINISTRATIVE TASK AREA

BUILDING LEVEL ORGANIZATION

AND CONTROL OF SCHOOL PLANT

\begin{tabular}{|c|c|c|c|c|c|}
\hline Competency & Respondents & Essentialityl & $x^{2}$ & Procedure & $x^{2}$ \\
\hline \multirow{3}{*}{22} & Principals & $\begin{array}{l}\text { Moderately } \\
\text { important }\end{array}$ & \multirow{3}{*}{$\begin{array}{l}8.810 \\
d f=4\end{array}$} & $\begin{array}{l}\text { Pre-service } \\
\text { In-service } \\
\text { Experience }\end{array}$ & \multirow{3}{*}{$\begin{array}{l}3.697 \\
\text { af }=4\end{array}$} \\
\hline & Inspectors & $\begin{array}{l}\text { Moderately } \\
\text { important }\end{array}$ & & $\begin{array}{l}\text { Pre-service } \\
\text { Experience }\end{array}$ & \\
\hline & $\begin{array}{l}\text { Office } \\
\text { personnel }\end{array}$ & $\begin{array}{l}\text { Moderately } \\
\text { important }\end{array}$ & & $\begin{array}{l}\text { Pre-service } \\
\text { In-service } \\
\text { Experience }\end{array}$ & \\
\hline \multirow{3}{*}{23} & Principals & $\begin{array}{l}\text { Very } \\
\text { important }\end{array}$ & \multirow{3}{*}{$\begin{array}{l}8.501 \\
d f=4\end{array}$} & In-service & \multirow{3}{*}{$\begin{array}{l}10.420^{\star} \\
d f=4\end{array}$} \\
\hline & Inspectors & $\begin{array}{l}\text { Very } \\
\text { important }\end{array}$ & & $\begin{array}{l}\text { Pre-service } \\
\text { in-service }\end{array}$ & \\
\hline & $\begin{array}{l}\text { Dffice } \\
\text { Personnel }\end{array}$ & $\begin{array}{l}\text { Moderately } \\
\text { important }\end{array}$ & & In-service & \\
\hline \multirow{3}{*}{24} & Principais & $\begin{array}{l}\text { Moderately } \\
\text { important }\end{array}$ & \multirow{3}{*}{$\begin{array}{l}9.974^{*} \\
d f=4\end{array}$} & $\begin{array}{l}\text { In-service } \\
\text { Experience }\end{array}$ & \multirow{3}{*}{$\begin{array}{l}1.193 \\
d \tilde{t}=4\end{array}$} \\
\hline & Inspectors & $\begin{array}{l}\text { Very } \\
\text { important }\end{array}$ & & $\begin{array}{l}\text { In-service } \\
\text { Experienca }\end{array}$ & \\
\hline & $\begin{array}{l}\text { Office } \\
\text { personnel }\end{array}$ & $\begin{array}{l}\text { Moderately } \\
\text { important }\end{array}$ & & $\begin{array}{l}\text { In-service } \\
\text { Experience }\end{array}$ & \\
\hline
\end{tabular}

Reproduced with permission of the copyright owner. Further reproduction prohibited without permission. 
TABLE 9--Continued

\begin{tabular}{|c|c|c|c|c|c|}
\hline Eompetency & Respondents & Essentiality & $x^{2}$ & Procedure & $x^{2}$ \\
\hline \multirow{3}{*}{25} & Principa is & $\begin{array}{l}\text { Möderately } \\
\text { important }\end{array}$ & \multirow{3}{*}{$\begin{array}{l}5.725 \\
d f=4\end{array}$} & $\begin{array}{l}\text { In-service } \\
\text { Experience }\end{array}$ & \multirow{3}{*}{$\begin{array}{l}6.630 \\
d f=4\end{array}$} \\
\hline & Inspectors & $\begin{array}{l}\text { Very } \\
\text { important }\end{array}$ & & $\begin{array}{l}\text { Pre-service } \\
\text { In-service } \\
\text { Experience }\end{array}$ & \\
\hline & $\begin{array}{l}\text { Office } \\
\text { personnel }\end{array}$ & $\begin{array}{l}\text { Moderately } \\
\text { important }\end{array}$ & & $\begin{array}{l}\text { Int-service } \\
\text { Experience }\end{array}$ & \\
\hline
\end{tabular}

*significant at 0.05 level

the principals and inspectors as very important, and by the centrai office as moderately important, the difierences were snuwn to be not significant. The mean score indicates that their perceptions as a :whole leaned more toward moderately important. In the procedure for acquiring this competency, the groups differed significantiy in their perceptions. The cni-square value of 10.420 reflects this perception. The principals and centrai office personnel perceived the acquisition of this competency to be througn in-service programs, wnile the inspectors feit that it should be acquired through pre-service and in-service programs.

Competency 24 (manage tine school piant and facilities) was perceived by the principals and central office personnel as moderately important while the inspectors perceived it as very important. The chi-square of 9.974 indicates that their perceptions on the essentiality of this competency differad significantly. In the procedure for acquiring this competency, their perceptions did not differ 
significantly. In-service and experience on the job were perceived by

ail ine responcents as the best procedures.

Sompetency 25 (operate the schcol within the framework of the

law) was perceived by the inspectors as very important, and by the

principals and central office personnel as moderateiy important.

Although they appeared to differ in their opinions regarding the

essentiality of this competency, the difference was shown to de not

significant. The mean score of 3.57 indicates that the respondents

as a whole perceived this competency as very important. In the pro-

cedure for acquiring this competency, the respondents as a whole saw

that in-service and experience on the job were the best means. Even

though the inspectors felt that pre-service course work could also be

effective, the difference did not appear to be significant.

Summary

The perceptions of the groups differed significantly on the essentiality of competency 24 , and on the procedure for acquiring competency 23. Competency 25 was considered very important, and competencies 22 and 23 moderately important. In-service and experience on the job were perceived as the best procedures for acquiring competencies 22, 24, ind 25. Pre-service was also considered an effective means for acquiring competency 22 .

Auxiliary services: cafeteria, health, and safety

Competencies under the task area of auxiliary services aro isted as competency 26 and 27 . The data in table 10 indicate the 
TABLE IO

RESPONSES TO ADMINISTRATIVE TASK AREA

AUXILIARY SERVICES

\begin{tabular}{|c|c|c|c|c|c|}
\hline Competency & Respondents & Essentiality & $x^{2}$ & Procedure & $x^{2}$ \\
\hline \multirow{3}{*}{26} & Principais & $\begin{array}{l}\text { Moderateiy } \\
\text { important }\end{array}$ & \multirow{3}{*}{$\begin{array}{l}3.946 \\
\text { df }=4\end{array}$} & $\begin{array}{l}\text { In-service } \\
\text { Experience }\end{array}$ & \multirow{3}{*}{$\begin{array}{l}7.606 \\
d f=4\end{array}$} \\
\hline & Inpsectors & $\begin{array}{l}\text { Moderately } \\
\text { important }\end{array}$ & & $\begin{array}{l}\text { Pre-service } \\
\text { In-service } \\
\text { Experience }\end{array}$ & \\
\hline & $\begin{array}{l}\text { Office } \\
\text { personnel }\end{array}$ & $\begin{array}{l}\text { Moderately } \\
\text { important }\end{array}$ & & In-service & \\
\hline \multirow{3}{*}{27} & Principals & $\begin{array}{l}\text { Moderately } \\
\text { important }\end{array}$ & \multirow{3}{*}{$\begin{array}{l}9.488 \\
d f=4\end{array}$} & $\begin{array}{l}\text { In-service } \\
\text { Experience }\end{array}$ & \multirow{3}{*}{$\begin{array}{l}2.569 \\
d f=4\end{array}$} \\
\hline & Inspectors & $\begin{array}{l}\text { Fairly } \\
\text { important }\end{array}$ & & Experience & \\
\hline & $\begin{array}{l}\text { Office } \\
\text { personnel }\end{array}$ & $\begin{array}{l}\text { Hoderately } \\
\text { important }\end{array}$ & & $\begin{array}{l}\text { In-service } \\
\text { Experience }\end{array}$ & \\
\hline
\end{tabular}

*significant at 0.05 level

perceptions of the principals, inspectors, and central office personnel concerning the competencies related to auxiliary services.

Competency 26 (organize and manage auxiliary services: cafeEeria, health, and safety) received a mean score of 2.88 indicating shat the respondents as a whole considered it as moderately important, In the procedure for acquiriing this competency, the central office personnel perceived that in-service was the best procedure, while the principals perceived that in-service and experience on the job could both be effective means. The inspectors saw that all three procedures 
(are-service, in-service, and experience) could be effective means. The cni-square value, however, indicates that these differences were not significant. The responderits as a whole perceived in-service and experience on the joo as the best means.

Competency 27 (evaluate auxiliary services) was perceived by the inspectors as fairly important, and by the principals and office personnel as moderately important. These differences were not significant. With a mean score of 2.63 from all the respondents, this competency was considered moderately important, and the procedure for acquiring it was through in-service programs and experience on the job. Even though the inspectors felt that experience on the job alone could be effective, this difference was not significant.

Summary

All the competencies related to auxiliary services were perceived by the respondents as moderately important and should be acquired through in-service programs and experience on the job.

Staff personnel: assignment, working conditions, certification and classification

The competencies in the area of staff personnel are listed as compeiency $28,29,30,31$, and 32 . The data presented in table 11 show the perceptions of the principals, inspectors, and the central office personnel on the competencies pertaining to this task area. Competency 28 (develop and improve the staff by attracting and retaining competent personnel) was perceived by the principals and office personnel as moderately important, and by the inspectors 
TABLE 11

RESPOHSES TO ADMINISTRATIVE TASK AREA

STAFF PERSONNEL

\begin{tabular}{|c|c|c|c|c|c|}
\hline Competency & Res pondents & Essentiality & $x^{2}$ & Procedure & $x^{2}$ \\
\hline \multirow{3}{*}{28} & Principals & $\begin{array}{l}\text { Moderately } \\
\text { important }\end{array}$ & \multirow{3}{*}{$\begin{array}{l}0.225 \\
d f=4\end{array}$} & $\begin{array}{l}\text { In-service } \\
\text { Experience }\end{array}$ & \multirow{3}{*}{$12.188^{\star}$} \\
\hline & Inspectors & $\begin{array}{l}\text { Very } \\
\text { important }\end{array}$ & & $\begin{array}{l}\text { Pre-service } \\
\text { Experience }\end{array}$ & \\
\hline & $\begin{array}{l}\text { Office } \\
\text { personnei }\end{array}$ & $\begin{array}{l}\text { Moderately } \\
\text { important }\end{array}$ & & Experience & \\
\hline \multirow{3}{*}{29} & Principals & $\begin{array}{l}\text { Very } \\
\text { important }\end{array}$ & \multirow{3}{*}{1.134} & $\begin{array}{l}\text { In-service } \\
\text { Experience }\end{array}$ & \multirow{3}{*}{$\begin{array}{l}5.868 \\
d f=4\end{array}$} \\
\hline & Inspectors & $\begin{array}{l}\text { Very } \\
\text { important }\end{array}$ & & $\begin{array}{l}\text { Pre-service } \\
\text { In-service } \\
\text { Experience }\end{array}$ & \\
\hline & $\begin{array}{l}\text { Office } \\
\text { personnel }\end{array}$ & $\begin{array}{l}\text { Very } \\
\text { important }\end{array}$ & & $\begin{array}{l}\text { Pre-service } \\
\text { In-service } \\
\text { Experience }\end{array}$ & \\
\hline \multirow{3}{*}{30} & Principals & $\begin{array}{l}\text { Moderately } \\
\text { important }\end{array}$ & \multirow{3}{*}{$\begin{array}{l}1.107 \\
d f=4\end{array}$} & $\begin{array}{l}\text { In-service } \\
\text { Experience }\end{array}$ & \multirow{3}{*}{$\begin{array}{l}7.890 \\
d f=4\end{array}$} \\
\hline & Inspectors & $\begin{array}{l}\text { Moderately } \\
\text { important }\end{array}$ & & Experience & \\
\hline & $\begin{array}{l}\text { Office } \\
\text { personnel }\end{array}$ & $\begin{array}{l}\text { Moderately } \\
\text { important }\end{array}$ & & $\begin{array}{l}\text { In-service } \\
\text { Experience }\end{array}$ & \\
\hline \multirow{3}{*}{31} & Principals & $\begin{array}{l}\text { Moderately } \\
\text { important }\end{array}$ & \multirow{3}{*}{$\begin{array}{l}2.573 \\
d f=4\end{array}$} & $\begin{array}{l}\text { In-service } \\
\text { Experience }\end{array}$ & \multirow{3}{*}{$\begin{array}{l}6.792 \\
d f=4\end{array}$} \\
\hline & Inspectors & $\begin{array}{l}\text { Very } \\
\text { important }\end{array}$ & & Experience & \\
\hline & $\begin{array}{l}\text { Office } \\
\text { personnel }\end{array}$ & $\begin{array}{l}\text { Hoderately } \\
\text { imoortant }\end{array}$ & & Experience & \\
\hline
\end{tabular}


TAELE 11--Continued

\begin{tabular}{|c|c|c|c|c|c|}
\hline Comperency & Respondents & Essentiality & $x^{2}$ & Procedure & $x^{2}$ \\
\hline \multirow{3}{*}{32} & Principals & $\begin{array}{l}\text { Very } \\
\text { important }\end{array}$ & \multirow{3}{*}{2.930} & Experience & \multirow{3}{*}{6.105} \\
\hline & Inspectors & $\begin{array}{l}\text { Moderately } \\
\text { important }\end{array}$ & & $\begin{array}{l}\text { Pre-service } \\
\text { In-service } \\
\text { Experience }\end{array}$ & \\
\hline & $\begin{array}{l}\text { Office } \\
\text { persunnei }\end{array}$ & $\begin{array}{l}\text { Very } \\
\text { important }\end{array}$ & & Experience & \\
\hline
\end{tabular}

*significant at 0.05 level

as very important. The difference in their perceptions was not significant. The mean score of 3.48 for this competency indicates that it was perceived by all the groups as moderately important. The perceptions of the groups differed significantly on the procedure for acquiring this competency. Although each group saw that experience on the job was an effective means for developing this competency, the principals and inspectors saw that in-service and pre-service, respectively, could also be effective.

Competency 29 (organize, coordinate, and supervise staff assignments) had a mean score of 3.53 indicating that the three groups perceived ic as a very important competency, and that it should be acquired through in-service and experience on the job. There were no significant differences in the perceptions of the three groups as to the essentiality of this competency and the procedure for acquiring it, even though the inspectors and central office personnel saw that preservice could also be an effective means. 
Eumoetency 30 :assist, advise, counsel, and provide guidance :0 the staff in their personal and school prodems) was perceived by all the respondents as moderately important with a mean score of 3.41 . :io significant differences was snown among the groups in their perceptions on the essentiality of this competency. The respondents as a wnole saw in-service and experience on the job as the most feasible means for acquiring this competency. Although the inspectors saw only experience on the job as an appropriate means, the difference was not significant.

Competency 31 (identify the needs and interests of the entire school staff) was perceived by the principals and central office personnel as moderately important, and by the inspectors as very imporiant. The differences in their perceptions were not significant. As a wnole the respondents perceived this competency as moderately important with a mean score of 3.47 and should be acquired through experience on the job. Although the principals saw also in-service as an Effective means for developing this competency, this difference was not significant.

Competency 32 (foster and maintain staff morale) received a mean score of 3.55 from all the respondents indicating that they serceived this competency as very important. The perceptions of the groups on the essentiality of this competency did not differ significantly even though the inspectors saw it as moderately important. The groups saw experience on the job as the best means for acquiring this competency. Although the inspectors saw that pre-service and in-service could also be effective means, this difference was not significant. 
Summary

Tro of the competencies related to stafi personnel were considered as very important and the rest as moderately important. Experience on the job was perceived as the best means for acquiring the various competencies except for competency 28 where the opinions of the groups differed significantiy. in-service was also considered effective for competencies 29 and 30 .

Staff improvement: evaluation, in-service training, and involvement in policy formation

The competencies in the area of staff improvement are listed as competency $33,34,35$, and 36 . The data presented in table 12 indicate the perceptions of the principals, inspectors, and central office personnel relating to staff improvement.

Enmetency 33 (evaluate school personnel) had a mean score of 3.24. It was perceived by all the groups as moderately important and shouid de icquired through pre-service and in-service programs. Their perceptions on the essentiality of this competency and the procedure for acquiring it did not differ significantly.

Competency 34 ikeep teachers abreast on current educational improvements) received a mean score of 3.29 . The three respondent groups considered the essentiality of this competency as moderately important, and that it should be acquired through in-service programs. The perceptions of the groups did not differ significantly on the essentiality and the procedure for acquiring this competency.

Competency 35 (encourage teachers to practice creative and innovative techniques) received a mean score of 3.38 from all the 
TABLE 12

RESPONSES TO AOMINISTRATIVE TASK AREA

STAFF IMPROVEMENT

\begin{tabular}{|c|c|c|c|c|c|}
\hline Competency & Respondents & Essentiality & $x^{2}$ & Procedure & $x^{2}$ \\
\hline \multirow{3}{*}{33} & Principals & $\begin{array}{l}\text { Moderately } \\
\text { important }\end{array}$ & \multirow{3}{*}{$\begin{array}{l}3.274 \\
d f=4\end{array}$} & In-service & \multirow{3}{*}{$\begin{array}{l}8.631 \\
d f=4\end{array}$} \\
\hline & Inspectors & $\begin{array}{l}\text { ioderately } \\
\text { important }\end{array}$ & & $\begin{array}{l}\text { Pre-service } \\
\text { In-service } \\
\text { Experience }\end{array}$ & \\
\hline & $\begin{array}{l}\text { Office } \\
\text { personnel }\end{array}$ & $\begin{array}{l}\text { Moderately } \\
\text { important }\end{array}$ & & $\begin{array}{l}\text { Pre-service } \\
\text { In-service }\end{array}$ & \\
\hline \multirow{3}{*}{34} & Principals & $\begin{array}{l}\text { Moderately } \\
\text { important }\end{array}$ & \multirow{3}{*}{$\begin{array}{l}4.526 \\
d f=4\end{array}$} & In-service & \multirow{3}{*}{$\begin{array}{l}2.790 \\
d f=4\end{array}$} \\
\hline & Inspectors & $\begin{array}{l}\text { Moderately } \\
\text { important }\end{array}$ & & In-service & \\
\hline & $\begin{array}{l}\text { Office } \\
\text { personnel }\end{array}$ & $\begin{array}{l}\text { Hoderately } \\
\text { important }\end{array}$ & & In-service & \\
\hline \multirow{3}{*}{35} & Principals & $\begin{array}{l}\text { Moderately } \\
\text { important }\end{array}$ & \multirow{3}{*}{$\begin{array}{l}7.915 \\
\mathrm{df}=4\end{array}$} & In-service & \multirow{3}{*}{$\begin{array}{l}6.094 \\
\text { of }=4\end{array}$} \\
\hline & Inspectors & $\begin{array}{l}\text { Very } \\
\text { important }\end{array}$ & & $\begin{array}{l}\text { In-service } \\
\text { Experience }\end{array}$ & \\
\hline & $\begin{array}{l}\text { Office } \\
\text { personnel }\end{array}$ & $\begin{array}{l}\text { Moderately } \\
\text { important }\end{array}$ & & In-seryice & \\
\hline \multirow{3}{*}{36} & Principals & $\begin{array}{l}\text { Moderately } \\
\text { important }\end{array}$ & \multirow{3}{*}{$\begin{array}{l}1.978 \\
d f=4\end{array}$} & In-service & \multirow{3}{*}{$\begin{array}{l}4.718 \\
d f=4\end{array}$} \\
\hline & Inspectors & $\begin{array}{l}\text { Very } \\
\text { important }\end{array}$ & & $\begin{array}{l}\text { In-service } \\
\text { Experience }\end{array}$ & \\
\hline & $\begin{array}{l}\text { Office } \\
\text { personnel }\end{array}$ & $\begin{array}{l}\text { Moderately } \\
\text { important }\end{array}$ & & In-service & \\
\hline
\end{tabular}

Reproduced with permission of the copyright owner. Further reproduction prohibited without permission. 
responcents. Hithougn tne inspectors perceived it as very important, ine respondents as a wnole saw it as moderately important. The difference in their perceptions was not significant. The perceived procedure for acquiring this competency was in-service programs. The inspectors saw that experience on the joo could also be effective, Jut tnis difference was not significant.

Competency 36 (involve the school staff in the development and re-evaluation of educational goals and objectives) was perceived by the principals and office personnel as moderately important, and jy the inspectors as very important. The diffitence in their percepEions was not significant. With a mean score of 3.34 , this competency was considered by all the respondents as moderately important and could be acquired through in-service programs. The perceptions of the groups on the procedure for acquiring this competency did not differ significantly even though the inspectors saw that experience on the job could also be an effective means.

Summary

All four competencies related to staff improvement were perceived as moderately important and should be acquired through inservice programs, except for competency 33 . Pra-service and in-service were considered as the best procedures for acquiring competency 33 .

Program evaluation and planning, curriculum development, instruction

The competencies related to program evaluation and planning are listed as competency $37,38,39$, and 40 . The data presented in tade 13 show the perceptions of the principals, inspectors and 
Eentral of ice personnel on the competencies relating to this task $3 r \geq a$.

Competency 37 (plan and evaluate the instructicnal and curriEular programs with the assistance of parents, teacners, and students) was perceived by all the respondents as moderately important with a mean score of 3.32. Althougn they aid not differ in their perceptions regaraing the essentiality of this competency, they differed significantly in their perceptions concerning the procedure for acquiring it. The chi-square value of 12.109 indicates this. The principais and central office personnel Felt that the acquisition of this competency snould be through in-service programs, while the inspectors indicated that it snould be acquired through pre-service course work. The principals also saw that in addition to in-service programs, this competency could also be developed through experience on the job.

Competency 38 (assess program needs involving teachers and students) was considered by all the respondents as moderately important with a mean score of 3.01. They were of the opinion that this competency could be acquired through in-service programs and experience on the job. The groups did not differ significantly in their perceptions concerning the essentiality of this competency and the procedure for acquiring it, even though the inspectors saw only experience on the job as the best procedure.

Competency 39 (provide curricular and instructional leadership) received a mean score of 3.37 indicating that the respondent groups perceived it as moderately important. The perceptions of the groups did not differ significant?y on the essentiality of this competency. Although the inspectors saw only pre-service and in-service 
TABLE 13

\section{?ESPONSES TO ADMINISTRATIVE TASK AREA \\ PROGRAM EVALUATION AND PLANNING, CURRICULUM DEVELOPMENT, AND INSTRUCT:ON}

\begin{tabular}{|c|c|c|c|c|c|}
\hline Competency & Respondents & Essentiality & $x^{2}$ & Procedure & $x^{2}$ \\
\hline \multirow{3}{*}{37} & Principals & $\begin{array}{l}\text { Moderately } \\
\text { important }\end{array}$ & \multirow{3}{*}{$\begin{array}{l}3.280 \\
\text { of }=4\end{array}$} & $\begin{array}{l}\text { In-service } \\
\text { Experience }\end{array}$ & \multirow{3}{*}{$\begin{array}{l}12.109+ \\
d f=4\end{array}$} \\
\hline & Inspectors & $\begin{array}{l}\text { Moderateiy } \\
\text { important }\end{array}$ & & Pre-service & \\
\hline & $\begin{array}{l}\text { Office } \\
\text { personnel }\end{array}$ & $\begin{array}{l}\text { Moderately } \\
\text { important }\end{array}$ & & In-service & \\
\hline \multirow{3}{*}{38} & Principals & $\begin{array}{l}\text { Moderately } \\
\text { important }\end{array}$ & \multirow{3}{*}{$\begin{array}{l}0.977 \\
d f=4\end{array}$} & $\begin{array}{l}\text { In-service } \\
\text { Experience }\end{array}$ & \multirow{3}{*}{$\begin{array}{l}5.287 \\
d f=4\end{array}$} \\
\hline & Inspectors & $\begin{array}{l}\text { Moderately } \\
\text { important }\end{array}$ & & Experience & \\
\hline & $\begin{array}{l}\text { Office } \\
\text { personnel }\end{array}$ & $\begin{array}{l}\text { Moderate } y \\
\text { important }\end{array}$ & & $\begin{array}{l}\text { In-service } \\
\text { Experience }\end{array}$ & \\
\hline \multirow{3}{*}{39} & Principals & $\begin{array}{l}\text { Moderately } \\
\text { important }\end{array}$ & \multirow{3}{*}{$\begin{array}{l}4.325 \\
d f=4\end{array}$} & $\begin{array}{l}\text { Pre-service } \\
\text { In-service } \\
\text { Experience }\end{array}$ & \multirow{3}{*}{$\begin{array}{l}2.697 \\
d f=4\end{array}$} \\
\hline & Inspectors & $\begin{array}{l}\text { Yery } \\
\text { important }\end{array}$ & & $\begin{array}{l}\text { Pre-service } \\
\text { In-service }\end{array}$ & \\
\hline & $\begin{array}{l}\text { Office } \\
\text { perscrnel }\end{array}$ & $\begin{array}{l}\text { Moderately } \\
\text { important }\end{array}$ & & $\begin{array}{l}\text { Pre-service } \\
\text { In-service } \\
\text { Experience }\end{array}$ & \\
\hline \multirow{3}{*}{40} & Principals & $\begin{array}{l}\text { Moderately } \\
\text { important }\end{array}$ & \multirow{3}{*}{$\begin{array}{l}3.412 \\
d f=4\end{array}$} & $\begin{array}{l}\text { In-service } \\
\text { Experience }\end{array}$ & \multirow{3}{*}{$\begin{array}{l}6.277 \\
d f=4\end{array}$} \\
\hline & Inspectors & $\begin{array}{l}\text { Moderately } \\
\text { important }\end{array}$ & & $\begin{array}{l}\text { Pre-service } \\
\text { In-service } \\
\text { Experience }\end{array}$ & \\
\hline & \begin{tabular}{|l|} 
Office \\
personnel
\end{tabular} & $\begin{array}{l}\text { Moderately } \\
\text { important }\end{array}$ & & In-service & \\
\hline
\end{tabular}


programs as ine sest procedures for acquiring this competency, the groups as a wnole saw all three procedures as effective. io signiFicant differences were snown among the groups in their perceptions of the procedure for acquiring this competency.

Competency 40 (supervise and coordinate education programs and experiences) was perceived by all the respondent groups as moderately important with a mean score of 3.28 . The perceptions of the groups did not differ significantly on the essentiality and on the procedure for acquiring this competency. As a whole the respondents saw in-service and experience on the job as the best means for acquiring this competency.

Summary

All four competencies related to program evaluation and pianning, curriculum development, and instruction were perceived as moderately important. The groups differed significantly in their percepEions on the procedure for acquiring competency 37 , jut agreed that in-service and experience on the job could be effective means for the rest of the competencies. They also agreed that pre-service could aiso be an effective means for acquiring competency 39.

Zesearch and development projects, investigation and testing of new iechniques, innovations and change

The competencies related to the task area of research and development are listed as competency 41,42 , and 43 . The data prasented in table 14 indicate the perceptions of the principals, inspectors, and central office personnel on the competencies pertaining to this task area. 
TABL $\equiv 14$

RESPONSES TO ADMINISTRATIVE TASK AREA
RESEARCH AND DEVELOP:IENT PROJECTS,
IVYESTIGATION AND TESTING OF NEN
TECHNIQUES, INNOVATIONS AND
GHANGE

\begin{tabular}{|c|c|c|c|c|c|}
\hline Competency & Respondents & Essentiality & $x^{2}$ & Procedure & $x^{2}$ \\
\hline \multirow{3}{*}{41} & Principals & $\begin{array}{l}\text { Moderately } \\
\text { important }\end{array}$ & \multirow{3}{*}{$\begin{array}{l}5.297 \\
d f=4\end{array}$} & In-service & \multirow{3}{*}{$\begin{array}{l}10.349 * \\
d f=4\end{array}$} \\
\hline & Inspectors & $\begin{array}{l}\text { Moderately } \\
\text { important }\end{array}$ & & Pre-service & \\
\hline & $\begin{array}{l}\text { Office } \\
\text { personnel }\end{array}$ & $\begin{array}{l}\text { iloderately } \\
\text { important }\end{array}$ & & $\begin{array}{l}\text { In-service } \\
\text { Experience }\end{array}$ & \\
\hline \multirow{3}{*}{42} & Principals & $\begin{array}{l}\text { Moderately } \\
\text { important }\end{array}$ & \multirow{3}{*}{$\begin{array}{l}6.057 \\
d f=4\end{array}$} & $\begin{array}{l}\text { In-service } \\
\text { Experience }\end{array}$ & \multirow{3}{*}{$\begin{array}{l}0.717 \\
d f=4\end{array}$} \\
\hline & Inspectors & $\begin{array}{l}\text { Very } \\
\text { important }\end{array}$ & & $\begin{array}{l}\text { In-service } \\
\text { Experience }\end{array}$ & \\
\hline & $\begin{array}{l}\text { Office } \\
\text { personnel }\end{array}$ & $\begin{array}{l}\text { Moderately } \\
\text { important }\end{array}$ & & $\begin{array}{l}\text { In-service } \\
\text { Experience }\end{array}$ & \\
\hline \multirow{3}{*}{$\$ 3$} & Principals & $\begin{array}{l}\text { Moderately } \\
\text { important }\end{array}$ & \multirow{3}{*}{$\begin{array}{l}3.501 \\
d f=4\end{array}$} & $\begin{array}{l}\text { In-service } \\
\text { Experience }\end{array}$ & \multirow{3}{*}{$\begin{array}{l}4.075 \\
d f=4\end{array}$} \\
\hline & Inspectors & $\begin{array}{l}\text { Moderately } \\
\text { important }\end{array}$ & & $\begin{array}{l}\text { In-service } \\
\text { Experience }\end{array}$ & \\
\hline & $\begin{array}{l}\text { Office } \\
\text { personnel }\end{array}$ & $\begin{array}{l}\text { Moderately } \\
\text { important }\end{array}$ & & $\begin{array}{l}\text { In-service } \\
\text { Experience }\end{array}$ & \\
\hline
\end{tabular}

*significant at 0.05 level

Competency 41 (employ professional research techniques and findings in the solution oi educational problems), which received a mean score of 2.78 , was perceived by the three groups as moderately 
imoortant. The perceptions of the groups on the essentiality of this competency did not difier significantly, but they did differ significantly on the procedure for acquiring it. The principals indicated that the procedure for acquiring this competency should be through in-service programs, while the inspectors saw that it should be through pre-service course work. The central office administrative personnel saw inat this competency snould be acquired through both in-service and experience on the job.

Competency 42 (initiate long-range planning procedure involving teachers and students) received a mean score of 2.97 , indicating that the respondent groups as a wnole consiaered this competency as moderately important. The perceptions of the groups did not differ significantly on the essentiality of this competency and the procedure For acquiring it. In-service and experience on the job were perceived as the best procedures for acquiring this competency. Competency 43 (initiate and encourage professional research) nad a mean score of 2.64 from all the respondents. The perceptions of the groups did not differ significantly on the essentiality of this competency and the procedure for acquiring it. The groups as a wnole perceived it as moderately important and shouid be acquired through in-service and experience on the job.

Sumnary

All the competencies related to research and development projects were considered as moderately important. The groups differed significantly in their perseptions on the procedure for acquiring 
zomoetency 4 , sut agraed that in-service and experience on the job would be the best means for the rest of the competencies.

\section{Ranking of the Twelve Administrative Task Areas}

The respondents were also requested to rank the administrative task areas on the basis of their essentiality for secondary-school principalship functions. This was done to determine the magnitude of the competency areas in terms of priority. The ranking score for each task area was computed by dividing the aggregate score each respondent group had assigned to each task area by the total number of respondents in each group. The data presented in table 15 indicate the scores received by each task area.

Using this technique the ranking of the twelve administrative task areas was generated. The data presented in tables 16, 17, and i8 indicate the ranking of the principals, inspectors, and central office personnel, respectively, in descending magnitude.

in order to determine whether the rankings of the three groups had some agreement, the data were subjected to statisticai analysis. Kendeli's coeficient of concordance was utilized to determine the degree of correlations between the rankings. The formula used was:

$$
\begin{aligned}
\qquad N=\frac{12 S}{m^{2}\left(N^{3}-N\right)} \\
\text { where } S=s u m \text { of squares of rank sums for } N \text { items, } \\
m=\text { the number of group rankings, } \\
N=\text { the number of items rated. }
\end{aligned}
$$


IABLE 15

RANKING SCORES OF IIIE TWELVE AUMINISIRATIVE TASK ARLAS

BY PRINCIPALS, INSPECTORS, AND

CENTRAL OFFICE PERSONNEL

\begin{tabular}{|c|c|c|c|}
\hline Administrative Task Area & $\begin{array}{l}\text { Principals' } \\
\text { Ranking }\end{array}$ & $\begin{array}{l}\text { Inspecturs' } \\
\text { Ranking }\end{array}$ & $\begin{array}{l}\text { Central Uftica } \\
\text { Persomel Ranking }\end{array}$ \\
\hline $\begin{array}{l}\text { 1. Policy development } \\
\text { 2. Business affairs: budget, accounting, } \\
\text { purchasing }\end{array}$ & $\begin{array}{l}6.05(6 \text { th }) \\
5.84(4 \text { th })\end{array}$ & $\begin{array}{l}3.83(2 n d) \\
5.29(4 \text { th) }\end{array}$ & $\begin{array}{l}7.30(9 t h) \\
6.22(3 r d)\end{array}$ \\
\hline $\begin{array}{l}\text { 3. Community services and community relations } \\
\text { 4. Pupil personnel: guidance, counseling } \\
\text { services }\end{array}$ & $\begin{array}{l}6.79(8 \mathrm{th}) \\
6.41(7 \mathrm{th})\end{array}$ & $\begin{array}{l}7.78(8 \mathrm{th}) \\
7.83(9 \mathrm{th})\end{array}$ & $\begin{array}{l}7.22(8 t h) \\
6.54(711)\end{array}$ \\
\hline $\begin{array}{l}\text { 5. Student activities, including sports and } \\
\text { music }\end{array}$ & $7.44(11(1))$ & $8.33(11 \mathrm{th})$ & $1.78(11(h)$ \\
\hline $\begin{array}{l}\text { 6. Pupil control: discipline and attendance } \\
\text { 7. Building level organization and control. } \\
\text { and school plant }\end{array}$ & $\begin{array}{l}5.90(5 \mathrm{th}) \\
6.85\left(9 \mathrm{th}_{1}\right)\end{array}$ & $\begin{array}{l}7.11(7 \mathrm{th}) \\
6.94(6 \mathrm{th})\end{array}$ & $\begin{array}{l}5.16(\text { ind }) \\
6.32(4 \mathrm{th})\end{array}$ \\
\hline $\begin{array}{l}\text { 8. Auxillilary services: cafeterid, trans- } \\
\text { portation, health, and safety }\end{array}$ & $8.77(12 \mathrm{th})$ & $8.72(12(11)$ & $7.86(12(1))$ \\
\hline $\begin{array}{l}\text { 9. Staff personnel: assiynment, working } \\
\text { conditions, certification, and } \\
\text { classification }\end{array}$ & $5.39(3 \cdot d)$ & $6.50(5 \mathrm{th})$ & b. $34(5 t h)$ \\
\hline $\begin{array}{l}\text { 10. Staff improvement: evaluation, in-service } \\
\text { training, involvement in policy fomation }\end{array}$ & $4.97(2 n d)$ & $4.00(3 r d)$ & $6.38(6 \mathrm{th})$ \\
\hline $\begin{array}{l}\text { 11. Progran evaluation and planning, curri- } \\
\text { culum development instruction }\end{array}$ & $4.64(1 s t)$ & $3.78(1 \mathrm{st})$ & $4.84(1 \mathrm{st})$ \\
\hline $\begin{array}{l}\text { 12. Research and development projects, } \\
\text { investigation and testing of new tech- } \\
\text { niques, innovations and cliange }\end{array}$ & $7.13(10 \mathrm{tl})$ & $8.11(10(11)$ & $7.43(10(h)$ \\
\hline
\end{tabular}


1. Program evaluation and planning, curriculum development, and instruction

2. Staff improvement: evaluation, in-service training, involvement in policy development

3. Staff personnel: assignment working conditions, certification, and classification

4. Business affairs: budget, accounting, purchasing

5. Pupil control: discipline and attendance

5. Policy development

7. Pupil personnel services: guidance and counseling services

3. Community services and community relations

9. Building level organization and control, and school plant

10. Research and development projects, investigation and testing of new techniques, innovations and change

11. Student activities, including sports and music

12. Auxiliary services: careteria, health, and safety

TABLE 17

RANKING OF THE TNELVE ADMINISTRATIVE TASK AREAS BY INSPECTORS

1. Program evaluation and planning, curriculum development, and instruction

2. Policy development

3. Staff improvement: evaluation, in-service training, involvement in policy formation

4. Business affairs: budget, accouting, purchasing

5. Staff personnel: assignment, working conditions, certification, and classification

6. Building level organization and control, and school plant

7. Pupil control: discipline and attendance

8. Community services and community relations

9. Pupil personnel services: guidance and counseling services

10. Research and development projects, investigation and testing of new techniques, innovations and change

11. Student activities, including sports and music

12. Auxiliary services: cafeteria, health, and safety 
1. Program evaluation and planning, curriculum development, and instruction

2. Pupil control: discipline and attendance

3. Business affairs: budget, accounting, purchasing

4. Suilding level organization and control, and school plant

5. Stafi personnel: assignment, working conditions, certification, and classification

6. Staff improvement: evaluation, in-service training, invoivement in policy formation

7. Pupil personnel services: guidance, counseling servicas

3. Community services and community relations

9. Policy development

10. Research and development projects, investigation and testing of new techniques, innovations and change

11. Student activities, including sports and music

12. Auxiliary services: cafeteria, health, and safety

Using this formula the correlation coeficient between the rankings of the principals, inspectors, and central office personnel was found to be 0.393 .

Since $N$ is greater than 7 , the chi-square test was utilized to test the significance of the coefficient of concordance $w$. The iormula that was used is $x^{2}=m(N-1) W$. Using this formula the chi-square was calculated to be 29.47 which is significant at the 0.05 level of confidence. This indicites that with a coefficient correlation of 0.893 , thare is a significant agreement between the rankings of the principals, inspectors, and central office personnel on the administrative task areas.

Although as a whole there was a high correlation of agreement in the rankings of the three groups, it was observed that there were 
noticeadie differences in their rankings of some of the task areas. taministrative task area 1 (policy development) was ranked sixth by the principals, second by the inspectors, and ninth by the central office personnel. Administrative task area 6 (pupil control: discipline and attendance) was ranked seventh by the principals and inspectors, wnile the central office personnel ranked it third. Administrative task area 7 (building level organization and control, and schooi plant) was ranked by the principals and inspectors as sixth, while the central office personnel ranked it fourth. The principals and inspectors ranked administrative task area 10 (staff improvement: evaluation, in-service training, involvement in policy formation) as third, while the central office personnel ranked it sixth.

The data presented in table 19 indicate the rankings of the three groups combined. The groups perceived administrative task area II (program evaluation and planning, curriculum development, and instruction) as top in importance, and administrative task area 3 (auxiliary services: cafeteria, health, and safety) as the least.

$$
\frac{\text { Summary of the Essentiality of the }}{\frac{\text { Competencies and the Procedure }}{\text { for Acquiring Them }}}
$$

The data that have been presented in the various tables demonstrated that the principals, inspectors, and central office personnel did not differ significantly in their perceptions of the essentiality of the forty-three competencies except for competency 18 and 24 . When the perceptions of the three groups were combined, six of the forty-one competencies in which they agreed were considered as very important (competencies $1,4,21,25,29$, and 32), and thirty-five 
TABLE 19

COMBINED RANKING OF ADMINISTRATIVE TASK

AT:EAS BY PRINCIFr:LS, INSPECTORS, AND

CENTRAL OFFICE PERSONNEL

1. Program evaluation and planning, curriculum development, and instruction

2. Jusiness affairs: budget, accounting, purchasing

3. Staff improvement: evaluation, in-service training, involvement in policy formation

4. Pupil control: discipline and attendance

5. Building level organization and control, and school plant

o. Policy development

7. Staff personnel: assignment, working conditions, certification, and classification

3. Community services and community relations

9. Pupil personnel services: guidance and counseling services

10. Research and development projects, investigation and testing of new techniques, innovations and change

11. Student activities, including sports and music

i2. Auxiliary services: cafeteria, health, and safety

were considered as moderately important (competencies $2,3,5,6,7$, $3,9,10,11,12,13,14,15,16,17,19,20,22,23,26,27,28,30$, $31,33,34,35,36,37,38,39,40,41,42,43)$. No competencies were identified by the respondents as fairly important or as not needed. The administrative task areas in which the various competencies were subsumed were ranked according to their essentiality. Analysis of the ranking showed that there was a significant agreement among the rankings of the principals, inspectors, and central office personnel. The prioritization of the administrative task areas was therefore based on the combined rankings of the three groups.

The data was also analyzed to determine the perceptions of the respondents on the procedures for acquiring the competencies. The perceptions of the three groups differed significantly on the 
procedure for acquiring nine of the competericies: $4,12,16,17,21$, $23,28,37$, and 41 (see zable 20). In the analysis of the rest of ine competencies in wnich there was agreement in their perceptions, it was noted that the groups perceived more than one procedure for developing some of the competencies. In some cases, all three procedures were considered by the groups as effective means. The competencies that the groups perceived could be developed through preservice were $11,20,22,33,39$. A majority of the competencies were perceived to be acquired through in-service and experience on the joo. Competencies that could be acquired through in-service programs were $1,2,3,5,5,7,11,13,18,20,22,24,25,26,27,29,30,33,34$, $35,36,37,38,39,40,42$, and 43 , and those that could be acquired through experience on the job were $1,2,3,5,6,7,8,9,10,13,14$, $15,18,19,22,24,25,26,27,29,30,32,36,37,38,42$, and 43 .

\section{Research iypotheses}

3ased on the purpose of this study two hypotheses were formulated to guide in the pursuit of this research. The research hypotheses were:

1. There is no significant difference between the perceptions of the central office personnel, inspectors, and principals on the essentiality of the competencies needed for secondary scnool principals in Sadan.

2. There is no significant difference between the perceptions of the central office personnel, inspectors, and principals on the procedure for acquiring these competencies. 
TABLE 20

SUMAPARY OF THE PERCEPTIONS OF THE PRINCIPALS, :NSPECTORS, AND CENTRAL OFFICE PERSONNEL

ON PROCEDURES IN WHICH THEY

DIFFERED SIGNIFICANTLY

\begin{tabular}{|c|c|c|c|c|}
\hline Competency & Respondent & \multicolumn{3}{|c|}{ Perceived Procedures } \\
\hline \multirow{3}{*}{4} & Principals & Pre-service & In-service & Experience \\
\hline & Inspectors & Pre-service & & \\
\hline & $\begin{array}{l}\text { Office } \\
\text { personnel }\end{array}$ & & In-service & \\
\hline \multirow{3}{*}{$i 2$} & Principals & & In-service & Experience \\
\hline & Inspectors & & & Züperiance \\
\hline & $\begin{array}{l}\text { Office } \\
\text { personnel }\end{array}$ & & In-service & \\
\hline \multirow{3}{*}{16} & Principals & Pre-service & in-service & \\
\hline & Inspectors & Pre-service & & \\
\hline & $\begin{array}{l}\text { Office } \\
\text { personnel }\end{array}$ & & In-service & \\
\hline \multirow{3}{*}{21} & Principals & & & Experience \\
\hline & Inspectors & Pre-service & & Experience \\
\hline & $\begin{array}{l}\text { Dffice } \\
\text { personnel }\end{array}$ & Pro-service & In-service & Experience \\
\hline \multirow{3}{*}{23} & Principals & \multicolumn{3}{|c|}{ In-service } \\
\hline & Inspectors & Pre-service & \multicolumn{2}{|l|}{ In-service } \\
\hline & $\begin{array}{l}\text { Office } \\
\text { personnei }\end{array}$ & \multicolumn{3}{|c|}{ In-service } \\
\hline
\end{tabular}


TABLE 20--Continued

\begin{tabular}{|c|c|c|c|c|}
\hline Competency & $\begin{array}{l}\text { Respondent } \\
\text { Groups }\end{array}$ & \multicolumn{3}{|c|}{ Perceived Procedures } \\
\hline \multirow{3}{*}{28} & Principals & \multicolumn{3}{|c|}{ in-service } \\
\hline & Inspectors & Pre-service & & Experience \\
\hline & $\begin{array}{l}\text { Office } \\
\text { personnel }\end{array}$ & & & Experience \\
\hline \multirow{3}{*}{37} & Principals & & In-service & Experience \\
\hline & Inspectors & \multicolumn{2}{|l|}{ Pre-service } & \\
\hline & $\begin{array}{l}\text { Office } \\
\text { personnel }\end{array}$ & \multicolumn{3}{|c|}{ In-service } \\
\hline \multirow{3}{*}{41} & Principals & \multicolumn{3}{|c|}{ In-service } \\
\hline & Inspectors & \multicolumn{3}{|l|}{ Pre-service } \\
\hline & $\begin{array}{l}\text { Office } \\
\text { personnel }\end{array}$ & & In-service & Experience \\
\hline
\end{tabular}

The data presented in tables 21 to 63 in appendix $E$ indicate that the perceptions of the central office personnel, inspectors, and principals differed significantly at the 0.05 level of significance on the essentiality of competencies 18 and 24 . This leads to the rejection of hypothesis : î cumpetentcies 19 (maintain participation standards for student activity programs) and 24 (manage the school plant and facilities). Hypothesis 1 is retained for the rest of the competencies.

In the procedure for acquiring the competencies, the perceptions of the principals, inspectors, and central office personnel differed significantly at the 0.05 level of significance on competencies 
$4,2,: 0,: 7,2 !, 23,28,37,41$. Hypothesis 2 is rejected in the

srocedure for acquiring the following competencies:

$\therefore$ Organize, supervise, and manage the business affairs of the school

i2. Encourage students to participate in developing and implementing student programs

16. Organize, coordinate, and administer the total activities program

17. Evaluate the student activities program

21. Establish student control and disciplinary procedures with the assistance of parents, teachers, and students

23. Schedule the school academic program

28. Develop and improve the staff by attracting and retaining competent personnel

37. Plan and evaluate the instructional and curricular programs with the assistance of teachers and students

41. Employ professional research techniques and findings in the solution of educational problems.

This chapter presented the analys is of the data to answer the major and sub-purposes of this research. The summary of the findings, conclusions, and recommendations are presented in chapter $y$. 
CHAPTER $/$

SUMMARY, CONCLUSIONS, AND RECOMMENDATIONS

\section{Summary}

The purpose of this study was to determine the basic competencies needed for secondary-school principalship duties in Sabah as perceived by principals, inspectors, and central office personnel. In order to treat the investigation adequately the perceptions of the groups on the procedures for acquiring the competencies were sought for, and the correlation of perceptions among the groups were analyzed. It was expected that the findings of this study would be of $y a$ ? ue to the school inspectors and departmental officers in planning for in-service programs for principals and to institutions that prepare individuals for principalship responsibilities.

The review of literature conducted as a background for this study revealed that the competency-based program for training school administrators is growing. The literature claimed that basic to the success of any competency-based program was the identification of competencies required for a particular position. In general, the literature reveaied that increasing attention had been focused on the competencies of principais. Much attention had been devoted to Jefining and listing competencies necessary for principalship duties for a particular location. Competencies were listed in general and 
in very specific ierms. Some articles listed competencies as job Functions and others listed them in terins of parsonal skills.

The literature recognized the competencies needed for princiJalship duties should be identified for establishing pre-service, internsnip, or in-service programs. There was a growing consensus that the most productive method for developing the competencies of principals was througn internship or in-service frograms.

The instrument that was utilized to generate the data for this study had forty-tinree competency statements in twelve administrative task areas. The questicnnaires were mailed to eighty-eight secondaryschool principals, twenty-three school inspectors, and forty-eight central office personnel in Sabah. Usable questionnaires were returned by 68 percent of the principals, 78 percent of the inspectors, and 77 percent of the central office personnel. The total response rate was 72 percent.

Jescriptive statistical procedures were utilized in analyzing the data which were compiled into simple frequency distributions (numjer and percentage) by category for each of the forty-three competency statements. The administrative task areas in which the competencies Here subsumed were then rank-ordered in descending magnitude from I to 12 to show how the respondents perceived the priority of the competencies by area. Cni-square analysis based on the frequency distributions was used to test the hypotheses that there were no significant differences in the proportions of responses the respondents had assigned on the competencies. The 0.05 level of significance was established for rejecting the hipotheses. 
when ine responses of the principals, inspectors, and central office personnel were analyzed, it was found that there was no significant differences ooserved among the perceptions of the three groups on the essentiality of forty-one (95 percent) of the competencies. The cotal responses of the population indicated that six (14 percent) of the competencies were regarded as very important, and thirty-five (79 percent) as moderately important. Vo competencies were perceived as fairly important or as not impurtant. The following list indicates how the respondents perceived the essentiality of the forty-one competencies in which there was agreement in their perceptions:

1. Competencies perceived as very important--listed according to the original competency numbering.

1. Nork with the school board, school inspectors, supervisors, and staff personnel in the establishment, coordination, and interpretation and enforcement of educational policies

4. Organize, supervise, and manage the business affairs of the school

21. Establish student control and disciplinary procedures with the assistance of teachers, parents, and students

25. Operate the school with in the framework of the law

29. Jrganize, coordinate, and supervise staff assignments

32. Foster and maintain staff morale

2. Competencies perceived as moderately important--listed according

to the original competency numbering.

2. Consult with the department of education personnel on educational and organizational matters

3. Serve as liaison between the school, the district, and the state

j. Make resources (supplies, mivey, equipment, etc.) available to the staff 
5. itilize resources and money to provide tne education program in nis/her scnool

7. Estadisn a Jublic relations program with the community (parents, teachers, and students)

3. Communicate with school patrons

9. Mediate disputes between parents, teaciers, staff, and students

10. Identify the community forces which affect the operation of the school and the implications of those forces

11. Utilize counseling tecinniques and provide a guidance program for students

12. Encourage students to participate in developing and implemerting student programs

13. Establish methods for reporting pupil programs

14. Advocate (speak for) the students when appropriate

15. Communicate with students concerning all aspects of their school life

16. Organize, coordinate, and administer the total activities program

i7. Evaluate student activities program

19. Maintain a program of spectator control at ail school activities

20. Establish attendance accounting system

22. Organize and manage a school program which implements the school philosophy

23. Scheduie the school academic program

26. Organize and manage auxiliary services (cafeteria, health, and safety)

27. Evaluate auxiliary services

28. Develop and improve the staff by attracting and retaining competent personnel

3i. Assisi, advise, counsal, and provide guidance ii tre staff in their personai wiri schnol protiems 
31. dentify the needs and interesis of the entire school staff

33. Evaluate school personnel

34. Leep ceacners adreast about current educational improvements

35. Encourage teacners to practise creative and innovative techniques

36. inrolve the school staff in the development and re-evaluation of educational goa is and objectives

37. Plan and evaluate the instructional and curricular programs with the assistance of teachers and students

38. Assess program needs involving teachers and studentz

39. Provide curricular and instructional leadersnip

40. Supervise and coordináte educational programs and experience

41. Employ professional research techniques and findings in the solution of educational problems

42. Initiate long-range planning procedure involving teachers and students

43. Initiate and encourage professional research When the competencies, by administrative task areas, were ranked, a significant agreement among the perceptions of the respondent groups was noted. The priorities of the competency areas were ranked as follows in descending magnitude:

1. Staff evaluation and planning, curriculum development, and iristruction

2. Business affairs: budget, accounting, purchasing

3. Staff improvement: evaluation, in-service training, irivolvement in policy formation

4. Pupil contro?: discipline and attendance

5. Building levei organization and control of school plant

6. Policy development

7. Staff personnel: assignment, working conditions, certification, and classification 
3. Community services and community relations

3. Pupil personnel services: guidance, counseling services

10. Research and development projects, investigation and testing of new techniques, innovations and change

ii. Student activities, including sports and music

12. Auxiliary services: cafeteria, health, and safety In the section which pertairs to the procedure for acquiring the competencies, significant differences were noted in the perceptions of the principals, inspectors, and central office personnel on nine (21 percent) of the competencies--4, 12, 16, 17, 21, 23, 28, 37, and 41 . The perceptions of each group on these competencies are summarized in table 20 on pages 81 and 82 . Althougn there was no attempt made to investigate the reasons wny the groups differed in their spinions, the differences in their perceptions do infer that the three groups nad different expectations as to where the principals ought to find answers to the problems they encounter on the joo on these nine competencies.

in the analysis of the remaining competencies in which there was agreement in their perceptions, the groups saw more than one procedure that could be eifective for developing the competencies. The total population saw that five (12 percent) of the forty-three competencies could be developed through pre-service course work, twenty-seven (63 percent) through in-service programs, and twentyeight (65 percent) through experience on the job. The following list indicates now the respondents perceived the acquisition of the competencies which are listed according to the original competency numberinis. 
$\therefore \quad$ impetencies shat could be acquired tnrough pre-service:

11. Jtilize counseling techniques and provide a guidance program for students

20. Establish attendance accounting procedures

22. Organize and manage a school program which implements the school philosophy

23. Schedule the school academic program

39. Provide curricular and instructional leadership

2. Competencies that could be acquired through in-service:

1. Nork with the school board, school inspectors, supervisors, and staff personnel in the establishment, coordination, and interpretation and enforcement of educational policies

2. Consult with department of education personnel on educational and organizational matters

3. Serve as liaison between the scnool, the district, and the state

5. Make resources (supplies, money, equipment, etc.) available to the staff

j. Utilize resources and money to provide the educational program in nis/her school

7. Establish a public relations program with the comunity (parents, teacners, and students)

11. Utilize counseling techniques and provide a guidance program for students

13. Establish netnods for reporting pupil programs

18. Maintain participation standards for student activity programs

20. Evaluate the student act vities prngram

22. Organize and manage a schoo! program which implements the school philosophy

24. Manage the school plant and facilities

25. Operate the school within the framework of the law

26. Organize and manage auxiliary services (cafeteria, heaith, and safety) 
27. Ëaluate juxiliary services

29. Jrganize, coorainate, and supervise staff assignments

30. Assist, advise, counsel, and provide guidance to the staff in their persinal and school problems

33. Evaluate school personnel

34. Keep teachers abreast about surrent educational improvements

35. Encourage teachers to practise creative and innovative techniques

36. Involve the school staff in the development and re-evaluation of educational goals and objectives

37. Plan and evaluate the instructional and curricular programs with the assistance of teachers and students

38. Assess program needs involving teachers and students

39. Provide curricular and instructional leadersnip

40. Supervise and coordinate educational programs and experiences

42. Employ professional research techniques and findings in the solution of educational problems

43. Initiate and encourage professional research

3. Competencies that could be acquired through experience on the job:

1. Nork with the school board, school inspectors, supervisors, and staff personnel in the establishment, coordination, and interpretation and enforcement of educational policies

2. Consult with department of education personnel on educational and organizational matters

3. Serve as liaison between the school, the district, and tine state

5. Make resources (supplies, money, equipment, etc.) available to the staff

5. Utilize resources and money to provide the educational program in nis/her school

7. Establish a pubiic relations program with the comunity (parents, zeachers, and students) 
3. Eomunicate with school patrons

9. Mediate disputes between parents, teacners, and students

10. identify the community forces which affect the operation of the school and the implications of those forces

13. Establish methods for reporting pupil programs

14. Advocate (speak for) the students when appropriate

15. Communicate with students concerning all aspects of their school life

18. Maintain participation standards for student activity programs

19. Maintain a program of spectator control at all school activities

22. Organize and manage a school program which implements the school pinilosophy

24. Manage the school plant and facilities

25. Operate the school within the framework of the law

26. Organize and manage auxiliary services (cafeteria, health, and safety)

27. Evaluate auxiliary services

29. Jrganize, coordinate, and supervise staff assignments

30. Assist, advise, counsel, and provide guidance to the staff in their personal and school problems

32. Foster and maintain staff morale

36. Invoive the school staff in the development and re-evaluation of educational goais and objectives

37. Plan and evaluate the instructional and curricular programs with the assistance of teaciers and students

38. Assess program needs involving teachers and students

39. Provide curricular and instructional leadership

42. Initiate long-range planning procedure

43. Initiate and encourage professional research 
Conclusions

ine following conclusions are arawn from the results of this study:

1. All forty-three basic competencies included in this study are considered important skills for principalsnip functions in Sabah, al though some competencies were perceived as more essential than others. Those competencies that are considered as very important pertain to: (a) the establishment, coordination, interpretation, and enforcement of educational policies, (b) organization, supervision, and management of business affairs of the school, (c) establishment of student control and disciplinary procedures, (d) organization, coordination, and supervision of staff assignments, (e) operation of the school within the framework of the law, and ( $f$ ) maintenance of staff morale.

2. The respondent groups perceived in-service programs and experience on the job as the most effective means for developing these competencies. in-service was perceived as a strong preference for developing all the competencies listed in the areas of (a) policy development, (b) auxiliary services, (c) staff improvement, and (d) program evaluation, including the ilajority of the competencies listed in the areas of (1) business affairs, (2) building level organiration and control of school plant, and (3) research and development projects. All the competencies listed in the area of community services and community relations, and a majority of those listed in the areas of (a) pupil personnel services, (b) student activities, and (c) staff personnel were perceived as competencies that could be 
deyeloped tnrougn experience on the job. it is noted that while the respondents in inis study indicated almost equal preference for inservice and experience on the job as the feasible means for developing ine competencies, the respondents in Lyons' study (1978) indicated a strong preference for experience on the job.

3. Pre-service course work was not perceived by the groups as a strong preference for developing the competencies. It is also noted that this iinding tends to support the conclusion reached by Lyons in his study of competencies needed for beginning principals in North Carolina. The few competencies which the respondents perceived could be acquired through pre-service course work pertain to: (a) the utilization of counseling techniques, (b) establishment of attendance accounting procedures, (c) implementation of the school philosophy through organization and management of school programs, (d) scheduling of the schoo! academic program, and (e) curricular ano instructional leadership.

\section{Recommendations}

The following recommendations are offered as a resuit of the conclusions arawn from this study:

1. The data from this study should be utilized by educational jersonnel who plan for the pre-service and in-service programs for principals in Sabah. This could provide a direction to the planners in their attempts to have relevant training programs for principals.

2. Communication between the inspectors, principals, and central office personnel shouid be improved particularly in the areas of (a) business affairs, (b) pupil personnel services, (c) student 
activities, (d) pupil control, (e) building level organization and concrol of school plant. (f) staff personnel, (g) program evaluation and planning, and (in) research and development projects. The three groups differed significantly in their perceptions of the procedure ior acquiring twenty-one percent of the competencies listed in these areas. It appeared that in some areas the principals expected inservice programs to provide them the answers to the problems they encounter on the joD, wnile the inspectors expected pre-service or experience on the job to provide them the answers. Improvement in the communication could be done through seminars or workshops.

3. The department of education should include in their inservice training programs for principals the following acimiristiative task areas: (a) policy development, (b) auxiliary services, (c) stafi improvement, (d) program evaluation and planning, (e) business affairs, (f) building level organization and control of school plant, (g) researcn and development projects. Most of the competencies listed in these areas were perceived by the respondents to be acquired through in-service. Priority should be given to (a) program evaluation and planning, (b) business affairs, (c) staff improvement, which the respondents ranked as the three top priorities in essentiality.

4. It was noted above that pre-service was not preferred for developing most of the competancies. Although no attempt was made to investigate the reasons why the respondents did not consider pre-service as a feasible means, the following possible reasons are suggested: (a) It is possible that most of the principals were placed into principalship positions without first naving taken formal education in the 
area sf educational administration. They therefore could not appreciate sre-service training. (b) It is also possible that what they had learned through pre-service training were not relevant to the actial cuties they perform as principals. With these possible reasons in mind the department of education should provide the principals with more opportunities to do advanced course work in the area of educational aaministration. Later, a follow-up study could be undertaken to determine whether their perceptions on pre-service remain the same and why they do not prefer this proceudre.

5. Institutions that provide courses in educational administration should include the following competency areas in their course offerings: (a) pupil personnel services, (b) pupil control, (c) building level organization and control of school piant, and (d) program evaluation and planning. The few competencies perceived by the respondents to be acquired through pre-service are listed in these areas.

o. A follow-up study could be conducted using the results of this study as the criteria to determine the level of performance of principals and to assess their specific needs for further training. 7. A similar study in different states in Malaysia could also je conducted to determine if the findings are pervasive across the country or if they are peculiar to the area researched. 
APPENDICES

Reproduced with permission of the copyright owner. Further reproduction prohibited without permission. 
APPENDIX A

NAMES AND ADDRESSES OF

PANEL OF JUDGES

Reproduced with permission of the copyright owner. Further reproduction prohibited without permission. 
NAMES AND ADORESSES OF PANEL OF JUDGES

1. Mr. Afandi Angkangon 185-3, Evergreen Terrace Carbondale, Illinois 62901

2. Mr. Abdul Rahmar Juman 175-5, Evergreen Terrace Carbondale, IIlinois 62901

3. Mr. Haji Ruhimir. Adzin 186-8, Evergreen Terrace Carbondale, Illinois 62901

4. Mr. Liew Cyn Chung 189-5, Evergreen Terrace Carbondale, 117 inois 62901

5. Mr. Yasin Amit 187-6, Evergreen Terrace Carbondale, Lllinois 02901

j. Mr. Othman Menudin 186-2 Evergreen Terrace Carbondale, 117 inois 62901

7. Mrs. Hasnan bte Oatuk Abdul Rahman $708 \mathrm{~W}$. Mill, Ivy Hall $\$ 202$ Carbondale, [11 inois 62901

3. Mr. Edmund Siagian A-49 Beecriwood Apartment Berrien Springs, Michigan 49103 


\section{APPENDIX B}

COMPETENCY STATEMENTS 
The foliowing tweive areas of competencies have consistently been identified as highly important by previous studies of secondary school principals. Please indicate your opinion with a check $(\checkmark)$ whether each of the competency statement is relevant or not relevant for the study of corpotencies needed by secondary school principals in Sabah. Include other suggestions in the spaces provided.

in:

Polioyr Jevelopnen:

Yot

1. Hork with the school board, school inspectors, supervisors, and staif personnel in the establishnent, coozdination, and interpretation and enforcenani o: scrosl policies.

2. Consult witid departinent of education personnel on educational and organizational matters.

3. Serve as liaison between ine school, the disirict, and the state.

4.

Eusiness iffairs: Eucjet, iccounting, Purciasine

1. Orzanize, supervise, and manage the business affairs of tine school.

2. Kake resources (supplies, noney, equipment etc.) available to tise staff.

3. Utilize resources and money to provide the educational program in nis/her school.

4.

Community Services and Comenunity Relations

2. Establish a public relations progran with the cormunity (parents, teachers, staff, anc students).

2. Communicate with school patrons.

3. Yediate disputes between parents, teachers, stafi and students.

Pelevan: $\quad$ ielevant

Identify the comunity forces which affect ihe operation of the school and the implications of those forces.

ร. 
2.pil Personnel: Suicance, Counseling Eervices

Not

Relevant Relerant

2. jtilize counselina zechniques and provide a zuidance proezan :or students.

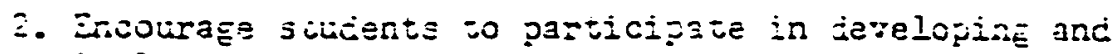
inplementinz student prograns.

3. Establish metrod jor Eeporting pupid programs.

-. ddrocate tise students wnen appropriate.

5. Communirate with studenis concerning all aspects or - :eir scrool life.

s.

Student Activities - Encludine music and scorts

2. Organize, coorcinate, and atiainijter ire totzI activi二ies prozrä.

2. Evaluate the stujent activities program.

3. Maintain a program of spectator contizol at all scnool activities.

$\therefore$ - Haintain participation standards for student activity prograns.

5.

Pupil Control: Discioline, Attendance

1. Establish attendance accounting procedures.

2. Establish student control and disciplinary procedures with the assistance of parents, teachers, and students.

3.

Euilding Ievel OrEanization and Conrol of School Plant

1. Organize and manage a school program which implements the school prilosophy.

2. Sciedule the sciool academic prozram.

3. ianaze tire school plant and sacilities.

1. Operaie the sckool within the framework of the lab.

j.

Auxiliary Services: Cafeteria, Transportation, :ealth and Saiet:

1. Organize and manage awiliary services (cafeteria, transportation, healti, anc saiety).

2. Evaluate auxiliary jervicas.

3.

Reproduced with permission of the copyright owner. Further reproduction prohibited without permission. 
Stzi: Pezsonnel: issignenent, rortsing conditions, Certilication, and Classification

1. Jevelop anc inprove tis stafi by atiracting and retaining competent personnel.

2. Jranize, coordinate, and superrise stâf assienmenis.

3. issist, advise, counsel, and provice zuiciance to tise sta: in their personal and sciool problems.

4. Identizy tine needs and interests of the enire school stai:.

5. Fosier and raintain staff morale.

o.

Staif Inzrovement: Eveluation. In-service Braining, Involvenent in jolicy jormation

I. Eraluate school personnel.

2. Keep teaciners abreast of current educational improvements.

3. incourage teachers to practise creative and innovative techniques.

4. Involve the school staff in developing educational goals and objectires.

$5:$

Frogram Jvaluation and Planning, Curriculum Develooment, Instruction

1. Plan and evaluate the instructional and curricular prograns with the assistance of parents, ieachers, and students.

2. Assess program needs involving jeachers, parents, and students.

3. Trovide curricular and instructional leadership.

4. Supervise-and coordinate educational programs and experiences.

5.

Research and Jevelopment 3rojects, Investigation and Testine oi hew Technigoues, Innovation and Cinange

1. Enploy professional research techniques and findines in the solution of educational problems.

2. Initiate long-range planning procedures involving parents, teachers, and students.

3. Initiate and encourage professional research. 4. 
APPENDIX C

THE QUESTIONNAIRE

Reproduced with permission of the copyright owner. Further reproduction prohibited without permission. 
QUESTICKNAIRE OE COAPETEACIES NBSDED BY SECONDARI-SCHOOL PRIXCIPATS

The purpose of this questionnalse is to deterodine the competencies needed for sacondary-school principalship in Sabah. It consists of three sections. Bach section should be answered following its own instruction.

Section 1: Information about the respondents.

1. Position:

Drector, Doputy Diructor, and Assistant Difector of Education; Dopartiental Socretarg/Officer; and Reglonal Education Offlcer. Scheol Inspector Principal

2. Years of expertence: In your earront position. In other educational edintstrative rork.

3. Blghest level of edncational attainment and other profossional trainfog:

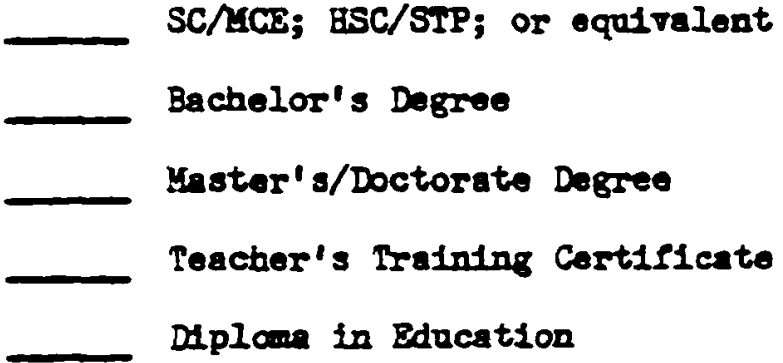

Section II: Rating of competenctes and the procedure for acquiring them.

Ints section consists of 43 competencies which aro frequentily considered necessary for the function of school principals. Colvern A shows a rating of scaje to fndtince the inportance of each coupetency for principalship functions in jabah, and colvm B shows a rating to indicate when you leel the campetoncy shoild be acquired; before entering the principalship work (pre-service), during internship or in-oervice trainting, or experience on the job. Clrcle jour rating using the following goride.

Colum A

4 - Very 1eportant

3 - Moderately important

2 - Falris important

1 - Hot important

\section{Colmon B}

1 - Pre-service coursewrork

2 - In-service training

3 - Beperfience on the job 
A secondary-ochool principal in Sabah should have the ability to:

Policy Dovelopment

(1) 123 is Work ofth the scinool board, school 1nspectors, suporvisors, and stafl personnel in the estab11shment, coordination, and interprotation and enforcenent of edveational policies.

(2) : 234 Consult with Departinent of Education personnel on oducational and organizational matters.

(3) 1234 Serro as Ilaison between ths sabool, the district 1223 and the state.

Bustness Affalrs: Budget, Accounting, Purchasing

(4) 1234 Organdise, superwise, and manage the business 123 sffatrs of the scbool.

(5) 1234 Kake resourees (supplies, money, equtpment, etc) 123 avadlable to the staff.

(6) 1234 Ut11120 resources and money to propide the educational program in his/her school.

Commonty Services and Comunity Relations

(2) 1234 Bstablish a public relations progran with the courunity (parents, teschers, and students).

(8) 1234 conumicate with school patrons.

123

(9) 1234 Madiate disputes between parents, teachers, stasf, and students.

(10) 1234 Identify the commity forces which affect the of those forces.

Puptl Personnel Servtces: Guidence, Counseling Servtces

(II) 1234 Jtilize counseling tochniques and provide a guidance progran for students.

(12) 12234

Bncourage students to participate in developing and implementing student programs.

(13) 12234 Bsteblish mathods for reporting pupll programs. 123

(I4) 12234 ddvocate the students when appropriate. $\quad 123$

(15) 123 is Commescate with the students concerning all 123 


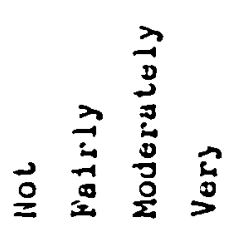

Student dctirities - including Music and Sports

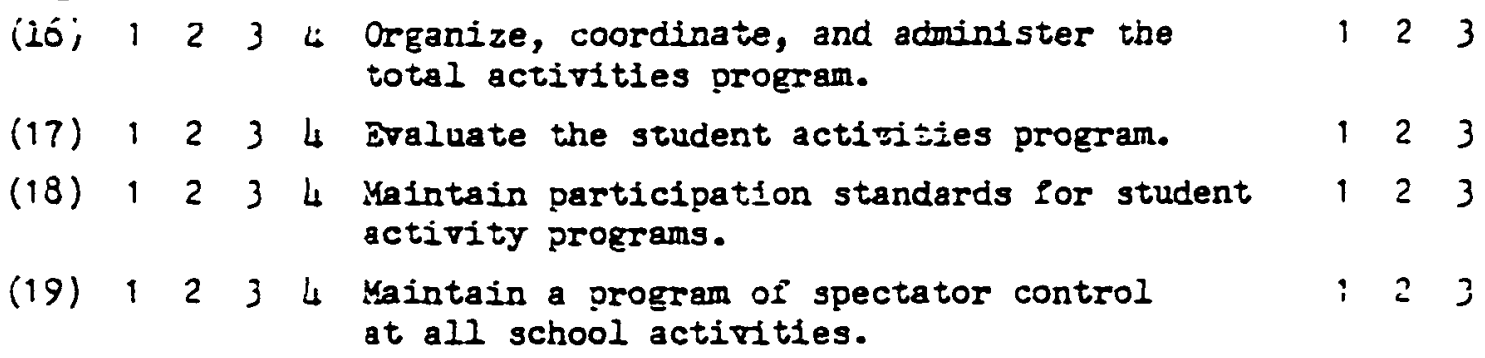

Pupil Control: Discipline, Attendance

$\begin{array}{lllllllll}\text { (20) } & 1 & 2 & 3 & 4 & \text { Establish attendance accounting procedures. } & 1 & 2 & 3 \\ \text { (21) } & 1 & 2 & 3 & 4 & \begin{array}{l}\text { Establish student control and disciplinary } \\ \text { procedures with the assistance of parents, } \\ \text { teachers, and students. }\end{array} & 1 & 2 & 3 \\ & & & \end{array}$

Sullding level Organization and Control of School Plant

$\begin{array}{llllllllll}\text { (22) } & 1 & 2 & 3 & 4 & \begin{array}{l}\text { Organize and ranage a school program which } \\ \text { implemants the school philosophy. }\end{array} & 1 & 2 & 3 \\ \text { (23) } 1 & 2 & 3 & 4 & \text { Schedule the school academic program. } & 1 & 2 & 3 \\ \text { (24) } & 1 & 2 & 3 & 4 & \text { Manage the school plant and facilities. } & 1 & 2 & 3 \\ \text { (25) } & 1 & 2 & 3 & 4 & \begin{array}{l}\text { Operate the school within the framework } \\ \text { of the law. }\end{array} & 1 & 2 & 3\end{array}$

iudilary Services: Cafeteria, Pransportation, Fealth and Safety

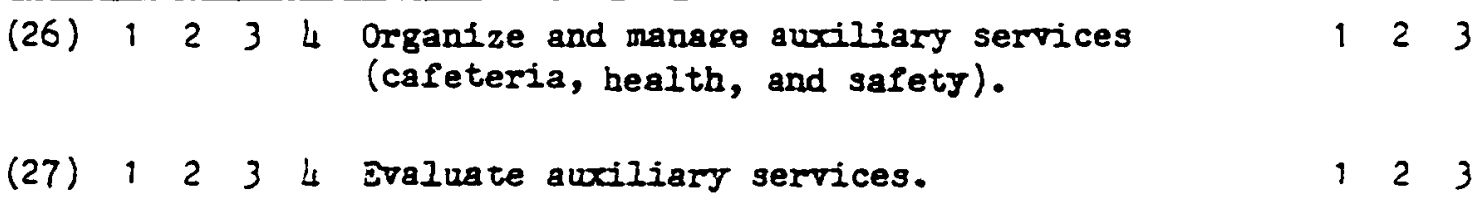

Staff Personnel: dssignment, Forking Conditions, Certification and Classification

(28) 12534 Develop and improve the staff by attracting 123 and retaining competent personnel.
(29) 1234 Organtze, coordinate, and supervise staff 123 assigaments.

(30) i 234 Assist, advise, counsel, and provide guidance i 23 to the stafi in theis personal and scinool problems.

(31) $12 \begin{array}{lllllll} & 2 & 4 & 4 & \text { Identify the needs and interests of the } & 1 & 2\end{array}$

(32) 1234 Foster and maintain staff morale. 123 


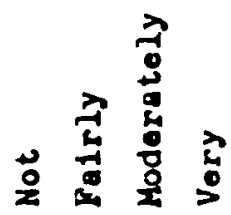

Staff Imorovement: Eraluation, In-service Training, Involvement In Policy Formation

(33) 12234 staluate school personnel. $\quad 1 \quad 23$

(34) 1234 Jeep teachers abreast of current educational 123 improvements.

(35) 1234 mourage teaciers to practise creative i 23 and innovative tecinniques.

(36) 1234 Intolve the school staff in the derelopment 123 and re-eraluation of educational goals and objectives.

Program Bralustion and Planning, Curriculum Development, Instruction

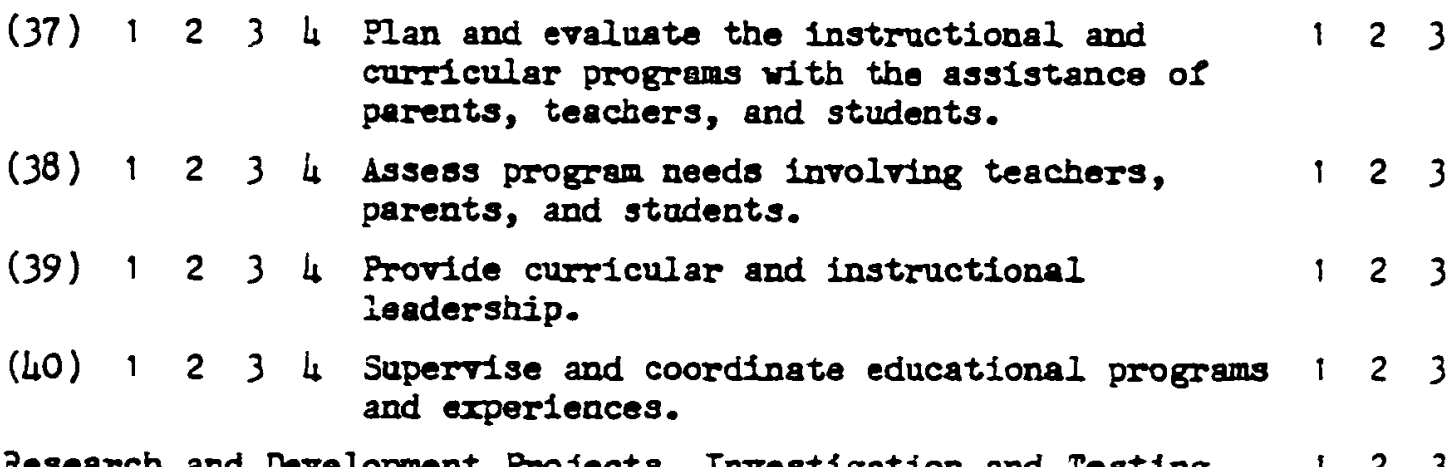
OP New Techniques, Innorations and Change

(4I) $12 \begin{array}{llllllll} & 2 & 4 & 4 & \text { Buploy professional research techniques and } & 2 & 3\end{array}$ flndings in the solution of educational problems.

(42) 1234 Initiate long-range planning procedure i 23 involving parents, teachers, and students.

(43) 123 is Initiate and encourgge professional research. 123 PLEAST ADD OTHER COMPEISNCIES IOU FEML ARE IMPORTANT
(44) $123 \quad 3$
(45) 12234 
Section III: 3anking of tdministrative Iask Areas

The following is a list of twelve administretive task areas of secondary school principalship. Please rank them from 1 to 12 in terms of thei importance as you perceite tinen for a principal. The area you feel is most important would be reted 1 and the least inportant is 12 .

Idrinistrative Task Areas

Ranking of Importance

1. Policy development

2. Zusiness affairs: budget, accounting, purchasing

3. Community services and community relations

4. Pupil personnel services: Gutiance, counseling jervices

5. Student activities, including sports and music

ó. Pupil control: discipline and attendance

7. Building level organfzaticn and control, and school plant.

3. duxillary services: cafeteria, bealth and safety.

Э. Staff personnel: assignment, working conditions, sertification, and classification.

10. Staff improvement: evaluation, in-service training, involvement in policy development.

11. Frogram evaluation and planning, curriculum development, instruction.

12. Zesearch and development projects, investigation and testing of new techniques, innovation and change. 
APPENDIX 0

COVERING AND FOLLOW-UP LETTERS

TO RESPONDENTS

Reproduced with permission of the copyright owner. Further reproduction prohibited without permission. 
A-72 Maplewood Apartment

Berrien Springs, idI 49103

Detober 7, 1981

I am a graduate student of Andrews University taking education majoring in educational administration. At present ! am working on my dissertation research which pertains to competencies needed for secondary school principalship duties in Sabah.

Before putting the survey instrument into its final form, the competency statements nave to be scrutinized for releyancy validity for use in Sabah. Due to your experience in and familiarity with the educational work in Sabah, you have been selected as one of the panel of judges for the validation of this instrument. Please read through the enclosed questionnaire and indicate your respcnse.

Thank you very much for your cooperation. The effort you are putting into this is greatly appreciated.

Very jincerely,

Charles Gaban 
A-72 Maplewood Apartment Berrien Springs, MI $\$ 9103$

U.S.A.

November 20, 1981

Jear Fellow Educator,

\section{A Research Questionnaire to Determine the Vecessary job Competencies for jecondary Schoul Principalship in Sabah}

! am a graduate student of Andrews University under the sponsorship of Sabah Foundation. At present I am working on my dissertation research which pertains to competencies needed for secondary school principalship in Sabah.

I am sure that you are aware of the current movement of competencybased programs for the preparation of educational leaders. The enclosed questionnaire is an attempt to determine which competencies are necessary for secondary school principals in Saban. As an educator I am requesting you to evaluate these competencies according to the instruction given.

This research is a partial fulfillment of the requirements of the education course I am pursuing at Andrews University. However, it is expected that the results of this study will be of value to the educational personnel in Sabah who deal with the pre-service and in-service programs for principals.

This study is very necessary for the completion of my course. Thus i am seeking for your cooperation. I appreciate it if this questionnaire could be completed and mailed within three days after you nave received it. A self-addressed envelope is enclosed for you to use to return this questionnaire to $\mathrm{Mr}$. Herbert Gaban. I have reguested him to receive and to forward them to me.

Thank you for your cooperation in this undertaking.

Very sincerely,

Charles Gaban

cc: iAr. Herbert Gaban, Department of Education, KK 
A-72 Maplewood Apartmerit

Berrien Springs, MI 49103

December 29, 1981

On November 20 you were mailed a copy of a survey instrument designed to collect data on the competencies for secondary school principalship duties in Saban. My record, however, indicates that I have not received the questionnaire I sent to you.

This research is very important for the completion of the course I am pursuing at Andrews University. It is also necessary that every questionnaire I have sent out is returned to me to increase the validity of this research. Thus I am pleading for your cooperation to participate in this undertaking.

Enclosed is another copy of the questionnaire in case the first one did not reach you. it self-addressed and stamped envelope is provided for your convenience to return it to Mr. Herbert Gaban. I have requested him to receive and to forward them to me.

Thank you for your cooperation.

Jery sincerely,

Charles Gaban

cc: Mr. Herbert Gaban, Department of Education, KK 
APPENDIX E

TABLES SHOWING RESPONSES

TO COMPETENCY STATEMENTS

Reproduced with permission of the copyright owner. Further reproduction prohibited without permission. 
IABLE 21

RESPUNSES 10 COHALILNCY 1: WORK WITII TIIE SCINOOL BUAKD, SCIOOL INSPECIORS SUPERVISORS, AND STAFF PLRSONNEL IN THL ESTABLISIIMENT, COORUINATION AND INTERPREIATION AND ENFORCEMENT OF EDUCATIONAL POLICIES

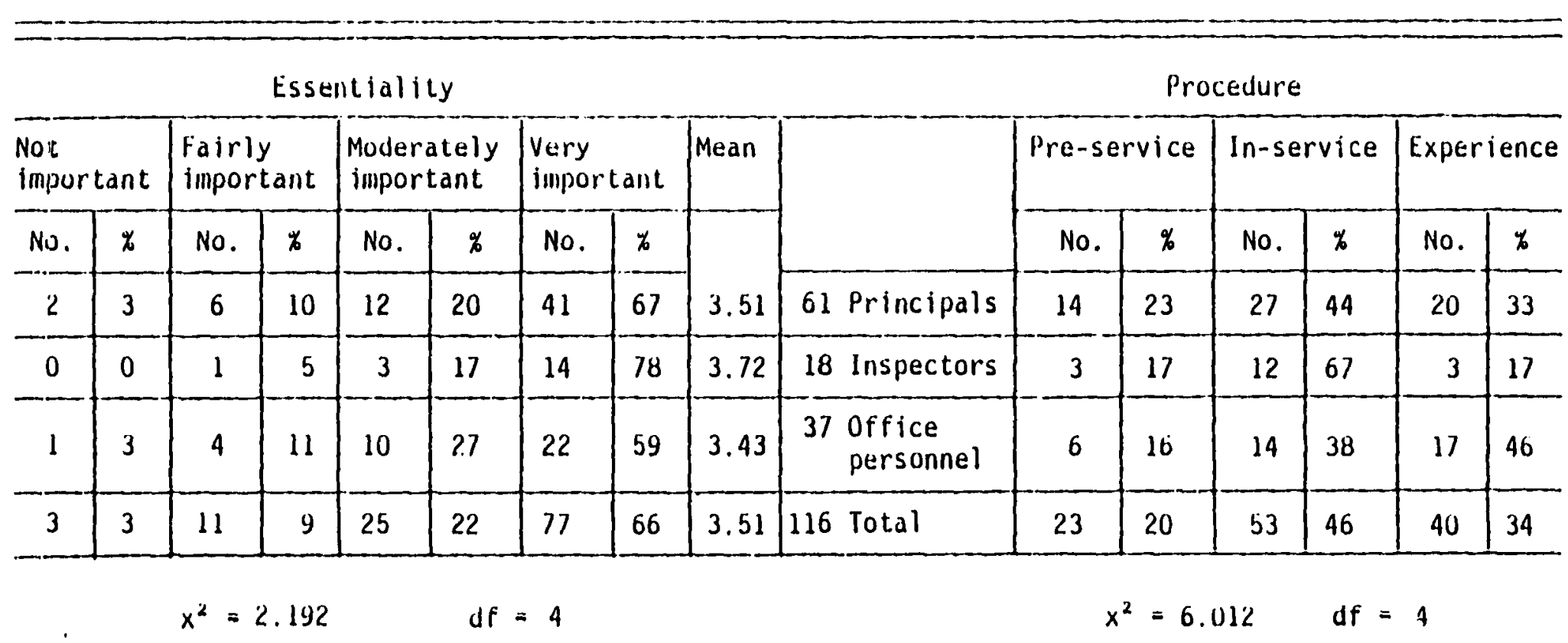


IABLE 22

RESPONSES TO COMPETENCY 2: CONSULT WITII DEPARTMENT

OF EOUCATION PERSONNEL. ON EDUCATIONAL AND

ORGANIZATIONAL MATTERS

\begin{tabular}{|c|c|c|c|c|c|c|c|c|c|c|c|c|c|c|c|}
\hline \multicolumn{10}{|c|}{ Essentiality } & \multicolumn{6}{|c|}{ Procedure } \\
\hline \multicolumn{2}{|c|}{$\begin{array}{l}\text { Not } \\
\text { important }\end{array}$} & \multicolumn{2}{|c|}{$\begin{array}{l}\text { rairly } \\
\text { important }\end{array}$} & \multicolumn{2}{|c|}{$\begin{array}{l}\text { Moderately } \\
\text { important }\end{array}$} & \multicolumn{2}{|c|}{$\begin{array}{l}\text { Very } \\
\text { important }\end{array}$} & \multirow[t]{2}{*}{ Mean } & & \multicolumn{2}{|c|}{ Pre-service } & \multicolumn{2}{|c|}{ In-service } & \multicolumn{2}{|c|}{ Experience } \\
\hline No. & $\%$ & No. & $\%$ & No. & $\%$ & No. & $\%$ & & & No. & $\%$ & No. & $\%$ & No. & $\%$ \\
\hline 1 & 2 & 7 & 11 & 30 & 49 & 23 & 38 & 3.23 & 61 Principals & 2 & 3 & 33 & 54 & 26 & 43 \\
\hline 0 & 0 & 2 & 11 & 6 & 33 & 10 & 56 & 3.44 & 18 Inspectors & 1 & 6 & 6 & 33 & 11 & 61 \\
\hline 1 & 3 & 5 & 13 & 16 & 43 & 15 & 41 & 3.22 & $\begin{array}{l}37 \text { Office } \\
\text { personnel }\end{array}$ & 1 & 3 & 18 & 48 & 18 & 48 \\
\hline 2 & 2 & 14 & 12 & 52 & 45 & 48 & 41 & 3.25 & 116 Total & 4 & 3 & 57 & 49 & 55 & 47 \\
\hline
\end{tabular}


TABLE 23

RESPONSES TO COMPETENCY 3: SERVE AS LIAISON BETWEEN

THE SCHOOL, THE UISTRICT, AND THE STATE

\begin{tabular}{|c|c|c|c|c|c|c|c|c|c|c|c|c|c|c|c|}
\hline \multicolumn{10}{|c|}{ Essentiality } & \multicolumn{6}{|c|}{ Procedure } \\
\hline \multicolumn{2}{|c|}{$\begin{array}{l}\text { Not } \\
\text { important }\end{array}$} & \multicolumn{2}{|c|}{$\begin{array}{l}\text { Fairly } \\
\text { important }\end{array}$} & \multicolumn{2}{|c|}{$\begin{array}{l}\text { Moderately } \\
\text { important }\end{array}$} & \multicolumn{2}{|c|}{$\begin{array}{l}\text { Very } \\
\text { important }\end{array}$} & \multirow[t]{2}{*}{ Mean } & & \multicolumn{2}{|c|}{ Pre-service } & \multicolumn{2}{|c|}{ In-service } & \multicolumn{2}{|c|}{ Experience } \\
\hline No. & $\%$ & No. & $\%$ & No. & $\%$ & No. & $\%$ & & & No. & $\%$ & No. & $\%$ & No. & $\not$ \\
\hline 5 & 8 & 16 & 26 & 22 & 36 & 18 & 20 & 2.87 & 61 Principals & 1 & 2 & 25 & 41 & 35 & 57 \\
\hline 0 & 0 & 1 & 6 & 9 & 50 & 8 & 44 & 3.39 & 18 Inspectors & 0 & 0 & 7 & 39 & 11 & 61 \\
\hline 3 & 8 & 8 & 22 & 19 & 51 & 7 & 19 & 2.81 & $\begin{array}{l}37 \text { office } \\
\text { personnel }\end{array}$ & 0 & 0 & 15 & 11 & 22 & 59 \\
\hline 8 & 7 & 25 & 22 & 50 & 43 & 33 & 28 & 3.29 & 116 Tot.al & 1 & 1 & 47 & 40 & 68 & 59 \\
\hline
\end{tabular}




\section{TABLE 24}

RESPONSES TO COMPEIENCY 4: ORGANILE, SUPERVISE, ANU MANAGL IIIE BUSINESS AFFAIRS OF THE SCHOOL

\begin{tabular}{|c|c|c|c|c|c|c|c|c|c|c|c|c|c|c|c|}
\hline \multicolumn{10}{|c|}{ Essentiality } & \multicolumn{6}{|c|}{ Procedure } \\
\hline \multicolumn{2}{|c|}{$\begin{array}{l}\text { Not } \\
\text { important }\end{array}$} & \multicolumn{2}{|c|}{$\begin{array}{l}\text { Fairly } \\
\text { important }\end{array}$} & \multicolumn{2}{|c|}{$\begin{array}{l}\text { Moderately } \\
\text { important }\end{array}$} & \multicolumn{2}{|c|}{$\begin{array}{l}\text { Very } \\
\text { important }\end{array}$} & \multirow[t]{2}{*}{ Mean } & & \multicolumn{2}{|c|}{ Pre-service } & \multicolumn{2}{|c|}{ In-service } & \multicolumn{2}{|c|}{ Experience } \\
\hline No. & $\%$ & No. & $\%$ & No. & $\%$ & No. & $x$ & & & No. & $\%$ & No. & $\%$ & No. & $x$ \\
\hline 1 & 2 & 6 & 33 & 14 & 23 & 40 & 66 & 3.52 & 61 Principals & 26 & 43 & 25 & 41 & 10 & 16 \\
\hline$\overline{1}$ & 6 & 2 & 11 & 2 & 11 & 13 & 72 & 3.39 & 18 Inspectors & 11 & 61 & 6 & 33 & 1 & 6 \\
\hline 1 & 3 & 3 & 8 & 11 & 30 & 22 & 59 & 3.46 & $\begin{array}{l}37 \text { office } \\
\text { personnel }\end{array}$ & 2 & 5 & 23 & 62 & 12 & 32 \\
\hline 3 & 3 & 11 & 9 & 27 & 23 & 75 & 65 & 3.50 & 116 Total & 39 & 34 & 54 & 47 & 23 & 20 \\
\hline
\end{tabular}


TABLE 25

RESPONSES 10 COMPETENCY 5: MAKE RESOURCES (SUPPLIES, MONLY, EQUIPMENT, ETC, ) AVAILABLE TO TIIE STAFF

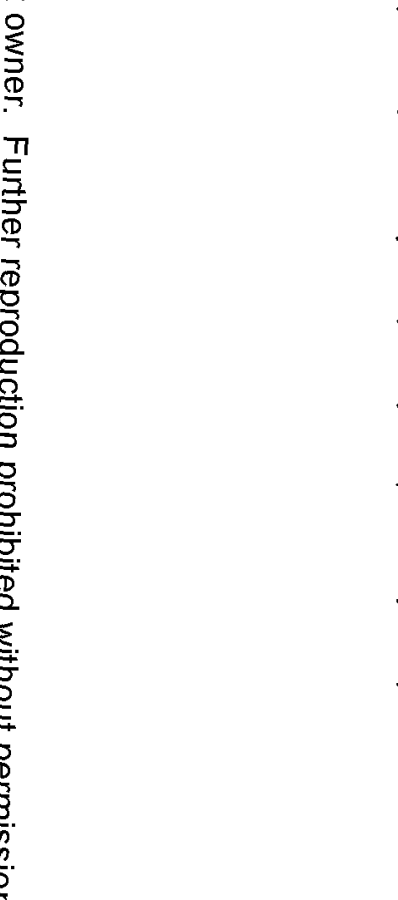

Essentiality

Procedure

\begin{tabular}{|c|c|c|c|c|c|c|c|c|c|c|c|c|c|c|c|}
\hline \multicolumn{2}{|c|}{$\begin{array}{l}\text { Not } \\
\text { important }\end{array}$} & \multicolumn{2}{|c|}{$\begin{array}{l}\text { Fairly } \\
\text { important }\end{array}$} & \multicolumn{2}{|c|}{$\begin{array}{l}\text { Moderately } \\
\text { important }\end{array}$} & \multicolumn{2}{|c|}{$\begin{array}{l}\text { Very } \\
\text { important }\end{array}$} & \multirow[t]{2}{*}{ Mean } & & \multicolumn{2}{|c|}{ Pre-service } & \multicolumn{2}{|c|}{ In-service } & \multicolumn{2}{|c|}{ Experience } \\
\hline No. & $x$ & No. & 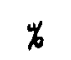 & No. & $\%$ & No. & $\%$ & & & No. & $\%$ & No. & $\%$ & No. & $\%$ \\
\hline 2 & 3 & 13 & 21 & 23 & 38 & 23 & 38 & 3.10 & 61 Principals & 0 & 0 & 38 & 68 & 23 & 38 \\
\hline 0 & 0 & 1 & 6 & 11 & 61 & 6 & 33 & 3.28 & 18 Inspectors & 0 & 0 & 7 & 39 & 11 & 61 \\
\hline 4 & 11 & 9 & 24 & 16 & 43 & 8 & 22 & 2.76 & $\begin{array}{l}37 \text { Office } \\
\text { personnel }\end{array}$ & 1 & 3 & 15 & 40 & 21 & 57 \\
\hline 6 & 5 & 23 & 20 & 50 & 43 & 37 & 23 & 3.02 & 116 Total & 1 & 1 & 60 & 52 & 55 & 47 \\
\hline
\end{tabular}


IABLE 26

RESPONSES TO COMPETENCY 6: UTILIZE RLSOURCES ANU MONLY

TO PROVIDE THE EUUCATIONAL PROGRAM

IN HIS/HER SCHOOL

\begin{tabular}{|c|c|c|c|c|c|c|c|c|c|c|c|c|c|c|c|}
\hline \multicolumn{8}{|c|}{ Essentiality } & \multicolumn{8}{|c|}{ Procedure } \\
\hline \multicolumn{2}{|c|}{$\begin{array}{l}\text { Not } \\
\text { important }\end{array}$} & \multicolumn{2}{|c|}{$\begin{array}{l}\text { Fairly } \\
\text { importarit }\end{array}$} & \multicolumn{2}{|c|}{$\begin{array}{l}\text { Moderately } \\
\text { important }\end{array}$} & \multicolumn{2}{|c|}{$\begin{array}{l}\text { Very } \\
\text { important }\end{array}$} & \multirow[t]{2}{*}{ Mean } & & \multicolumn{2}{|c|}{ Pre-service } & \multicolumn{2}{|c|}{ In-service } & \multicolumn{2}{|c|}{ Experience } \\
\hline No. & $\%$ & No. & $x^{\prime \prime}$ & No. & $\%$ & No. & $x$ & & & No. & $\%$ & No. & $\%$ & No. & $\%$ \\
\hline 0 & 0 & 5 & 8 & 25 & 41 & 31 & 51 & 3.43 & 61 Principals & 2 & 3 & 28 & 46 & 31 & 51 \\
\hline 0 & 0 & 21 & 1 & 7 & 39 & 9 & 50 & 3.39 & 18 Inspectors & 1 & 6 & 4 & 22 & 13 & 72 \\
\hline 1 & 3 & 6 & 16 & 14 & 38 & 16 & 43 & 3.22 & $\begin{array}{l}37 \text { Office } \\
\text { personnel }\end{array}$ & 2 & 6 & 16 & $4: 1$ & 19 & 51 \\
\hline 1 & 1 & 13 & 11 & 46 & 40 & 56 & 48 & 3.35 & 116 Total & 5 & 4 & 48 & 41 & 63 & 54 \\
\hline
\end{tabular}




\section{IABLE 27}

HESPUNSES TO COMPLIENCY 7: ESTABL ISH A PUBLIC RELATIONS PROGRAM WITII THE COMMUNITY (PARENTS, TEACIERS, AND STUDENTS)

\begin{tabular}{|c|c|c|c|c|c|c|c|c|c|c|c|c|c|c|c|}
\hline \multicolumn{8}{|c|}{ Essentiality } & \multicolumn{8}{|c|}{ Procedure } \\
\hline \multicolumn{2}{|c|}{$\begin{array}{l}\text { Not } \\
\text { important }\end{array}$} & \multicolumn{2}{|c|}{$\begin{array}{l}\text { Fairly } \\
\text { important }\end{array}$} & \multicolumn{2}{|c|}{$\begin{array}{l}\text { Moderately } \\
\text { important }\end{array}$} & \multicolumn{2}{|c|}{$\begin{array}{l}\text { Very } \\
\text { important }\end{array}$} & \multirow[t]{2}{*}{ Mean } & & \multicolumn{2}{|c|}{ Pre-service } & \multicolumn{2}{|c|}{ In-service } & \multicolumn{2}{|c|}{ Experience } \\
\hline No. & $\%$ & No. & $\%$ & No. & $x$ & No. & $\%$ & & & No. & $\%$ & No. & $\%$ & No. & $z$ \\
\hline 1 & 2 & 6 & 10 & 15 & 25 & 39 & 64 & 3.51 & 61 Principals & 12 & 20 & 19 & 31 & 30 & 49 \\
\hline 0 & 0 & 1 & 6 & 7 & 39 & 10 & 56 & 3.50 & 18 Inspectors & 2 & 11 & 7 & 39 & 9 & 50 \\
\hline 2 & 5 & 6 & 16 & 11 & 30 & 18 & 49 & 3.22 & $\begin{array}{l}37 \text { office } \\
\text { personnel }\end{array}$ & 4 & 11 & 16 & 43 & 17 & 46 \\
\hline 3 & 3 & 13 & 11 & 33 & 28 & 67 & 58 & 3.41 & 116 Total & 18 & 16 & 42 & 36 & 56 & 48 \\
\hline
\end{tabular}




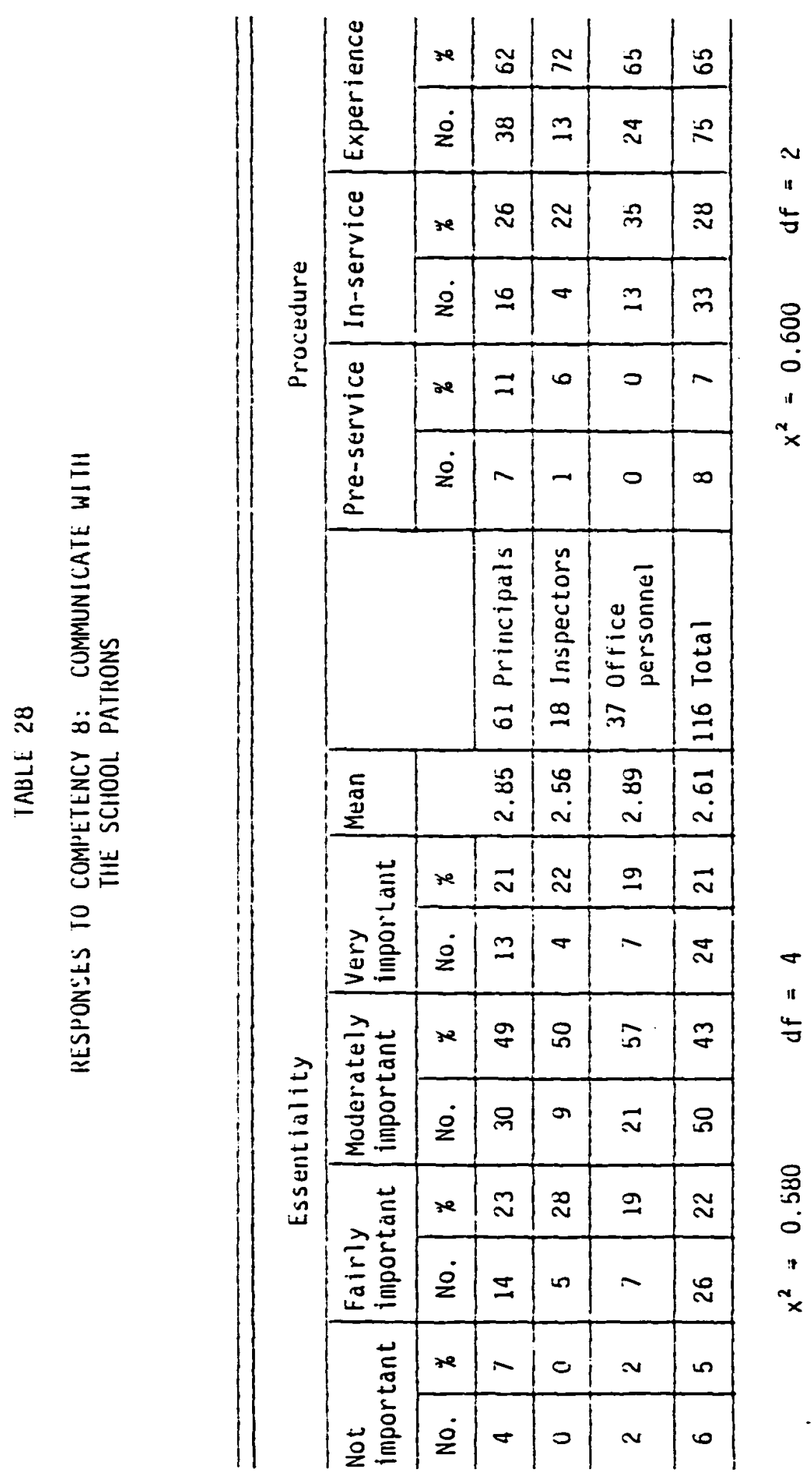


TABL.E 29

RESHONSES 10 COMPETENCY 9: MEDIATE UISPUIES BETWEEN PARENIS, TEACHERS, STAFF, ANI) STUDENTS

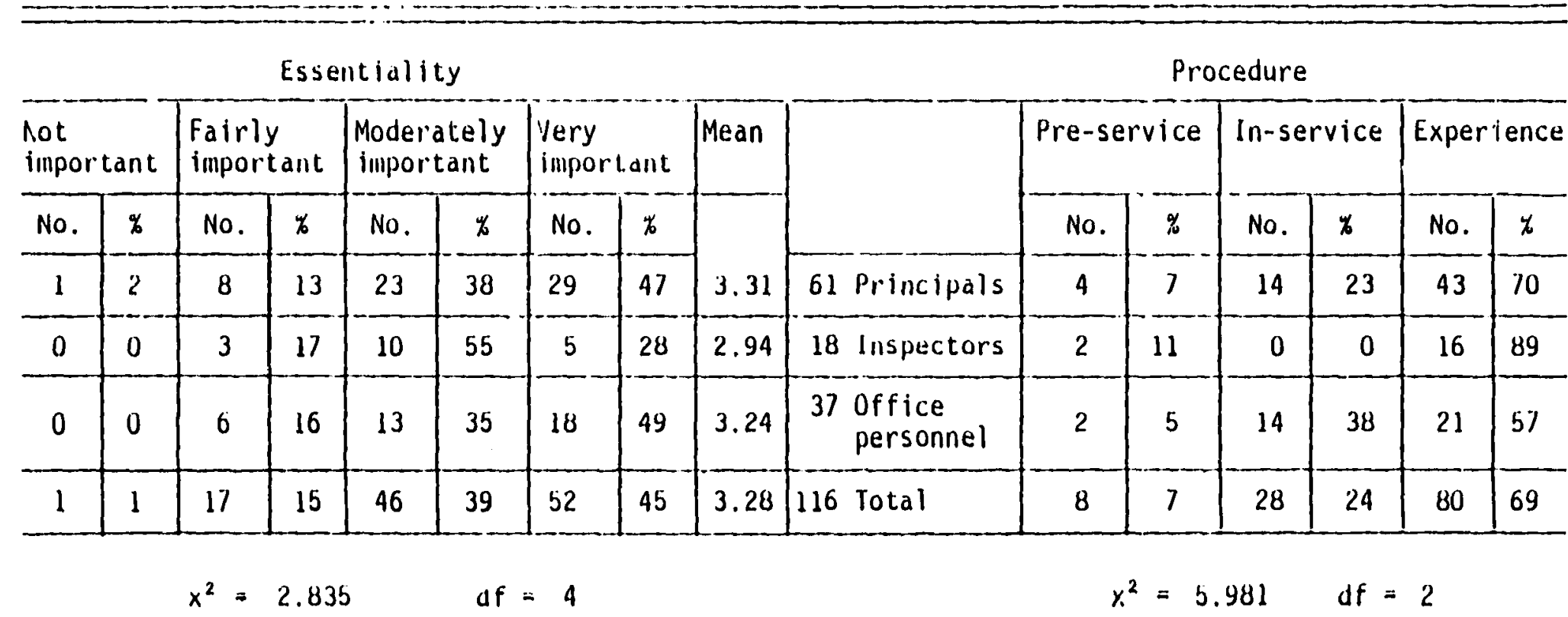


TABLE 30

RESSPONSES TO COMPETENCY 10: IDENTIFY IHE COMNUNITY FORCES WHICH AFFECT THE OPERATION OF THE SCHOOL AND THE IMPLICATIONS OF THOSE FORCES

\begin{tabular}{|c|c|c|c|c|c|c|c|c|c|c|c|c|c|c|c|}
\hline \multicolumn{10}{|c|}{ Essentiality } & \multicolumn{6}{|c|}{ Procedure } \\
\hline \multicolumn{2}{|c|}{$\begin{array}{l}\text { Not } \\
\text { important }\end{array}$} & \multicolumn{2}{|c|}{$\begin{array}{l}\text { Fairly } \\
\text { importa,lt }\end{array}$} & \multicolumn{2}{|c|}{$\begin{array}{l}\text { Moderately } \\
\text { important }\end{array}$} & \multicolumn{2}{|c|}{$\begin{array}{l}\text { Very } \\
\text { inluportant }\end{array}$} & \multirow[t]{2}{*}{ Mean } & & \multicolumn{2}{|c|}{ Pre-service } & \multicolumn{2}{|c|}{ In-service } & \multicolumn{2}{|c|}{ Experience } \\
\hline No. & $\%$ & No. & 16 & Ho. & $\%$ & No. & 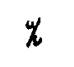 & & & No. & $\%$ & No. & $\%$ & No. & $y$ \\
\hline 1 & 2 & 8 & 13 & 23 & 38 & 29 & 47 & 3.31 & 61 Principals & 4 & 7 & 19 & 31 & 38 & 62 \\
\hline 1 & 6 & 3 & 16 & 9 & 50 & 5 & 28 & 3.00 & 18 Inspectors & 2 & 11 & 5 & 28 & 11 & 61 \\
\hline 1 & 3 & 11 & 30 & 14 & 38 & 11 & 30 & 2.95 & $\begin{array}{l}37 \text { Office } \\
\text { personnel }\end{array}$ & 4 & 11 & 14 & 30 & 19 & 51 \\
\hline 3 & 3 & 22 & 19 & 46 & 40 & 45 & 39 & 3.15 & 116 Total & 10 & 9 & 38 & 33 & 68 & 59 \\
\hline
\end{tabular}


TABLLE 31

RESPONSES IO COMPETENCY 11: UTILILE COUNSELING TECIINIQUES AND PROVIDE A GUIDANCE PROGRAM FOR STUDENTS

\begin{tabular}{|c|c|c|c|c|c|c|c|c|c|c|c|c|c|c|c|}
\hline \multicolumn{8}{|c|}{ Essentiality } & \multicolumn{8}{|c|}{ Procedure } \\
\hline \multicolumn{2}{|c|}{$\begin{array}{l}\text { Not } \\
\text { importanc }\end{array}$} & \multicolumn{2}{|c|}{$\begin{array}{l}\text { Fairly } \\
\text { important }\end{array}$} & \multicolumn{2}{|c|}{$\begin{array}{l}\text { Moderately } \\
\text { important }\end{array}$} & \multicolumn{2}{|c|}{$\begin{array}{l}\text { Very } \\
\text { important }\end{array}$} & \multirow[t]{2}{*}{ Mean } & & \multicolumn{2}{|c|}{ Pre-service } & \multicolumn{2}{|c|}{ In-service } & \multicolumn{2}{|c|}{ Experience } \\
\hline No. & $\%$ & No. & $\%$ & No, & $\%$ & No. & " & & & No. & $\%$ & No. & $\%$ & No. & $\%$ \\
\hline 1 & 2 & 8 & 13 & 20 & 33 & 32 & 52 & 3.36 & 61 Principals & 19 & 31 & 32 & 52 & 10 & 16 \\
\hline 0 & 0 & 0 & 0 & 10 & $b 6$ & 8 & 44 & 3.44 & 18 Inspectors & 6 & 33 & 10 & 56 & 2 & 11 \\
\hline 1 & 3 & 3 & 8 & 19 & 48 & 15 & 41 & 3.27 & $\begin{array}{l}37 \text { office } \\
\text { personnel }\end{array}$ & 13 & 35 & 16 & 43 & 8 & 22 \\
\hline 2 & 2 & 11 & 9 & 48 & 41 & 55 & 47 & 3.34 & 116 Total & 38 & 33 & 58 & 50 & 20 & 17 \\
\hline
\end{tabular}


TABLL 32

RESPONSES TO C.UMPETENCY 12: ENCOURAGE STUUENTS

TO PARTICIPATE IN DEVELOPING AND IMPLEMENTING 'JTUDENT PRUGRAMS

\begin{tabular}{|c|c|c|c|c|c|c|c|c|c|c|c|c|c|c|c|}
\hline \multicolumn{9}{|c|}{ Essentiality } & \multicolumn{7}{|c|}{ Procedure } \\
\hline \multicolumn{2}{|c|}{$\begin{array}{l}\text { Not } \\
\text { important }\end{array}$} & \multicolumn{2}{|c|}{$\begin{array}{l}\text { Fairly } \\
\text { important }\end{array}$} & \multicolumn{2}{|c|}{$\begin{array}{l}\text { Moderately } \\
\text { important }\end{array}$} & \multicolumn{2}{|c|}{$\begin{array}{l}\text { Very } \\
\text { important }\end{array}$} & \multirow[t]{2}{*}{ Mean } & & \multicolumn{2}{|c|}{ Pre-service } & \multicolumn{2}{|c|}{ In-service } & \multicolumn{2}{|c|}{ Experience } \\
\hline No. & $\%$ & No. & $y$ & No. & $\%$ & No. & $x$ & & & No. & $\%$ & No. & $\%$ & No. & $\%$ \\
\hline 0 & 0 & 6 & 10 & 26 & 43 & 29 & 47 & 3.37 & 61 Principals & 4 & 7 & 31 & 51 & 26 & 42 \\
\hline 0 & 0 & 3 & 17 & 6 & 33 & 9 & 50 & 3.33 & 18 Inspectors & 1 & 6 & 2 & 11 & 15 & 83 \\
\hline 1 & 3 & 5 & 13 & 17 & 46 & 14 & 38 & 3.19 & $\begin{array}{l}37 \text { office } \\
\text { personnel }\end{array}$ & 0 & 0 & 25 & 68 & 12 & 32 \\
\hline 1 & 1 & 14 & 12 & 49 & 42 & 52 & 45 & 3.31 & 116 Total & 5 & 4 & 58 & 50 & 53 & 46 \\
\hline
\end{tabular}


IABLE 33

RESPONSES 10 COMPETENCY 13: ESTABLISII METHOUS FOR REPORTING PUPIL PROGRAMS

\begin{tabular}{|c|c|c|c|c|c|c|c|c|c|c|c|c|c|c|c|}
\hline \multicolumn{10}{|c|}{ Essentidlity } & \multicolumn{6}{|c|}{ Procedure } \\
\hline \multicolumn{2}{|c|}{$\begin{array}{l}\text { Not } \\
\text { iliportant }\end{array}$} & \multicolumn{2}{|c|}{$\begin{array}{l}\text { Fairly } \\
\text { important }\end{array}$} & \multicolumn{2}{|c|}{$\begin{array}{l}\text { Moderately } \\
\text { important }\end{array}$} & \multicolumn{2}{|c|}{$\begin{array}{l}\text { Very } \\
\text { important }\end{array}$} & \multirow[t]{2}{*}{ Mean } & & \multicolumn{2}{|c|}{ Pre-service } & \multicolumn{2}{|c|}{ In-service } & \multicolumn{2}{|c|}{ Experience } \\
\hline No. & 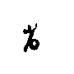 & No. & $\%$ & No. & $\%$ & No. & $\%$ & & & No. & $\%$ & No. & $\psi$ & No. & $\%$ \\
\hline 0 & 0 & 6 & 10 & 36 & 59 & 19 & 31 & 3.21 & 61 Principals & 6 & 10 & 29 & 47 & 26 & 43 \\
\hline 0 & 0 & 2 & 11 & 8 & 44 & 8 & 44 & 3.33 & 18 Inspectors & 0 & 0 & 5 & 28 & 13 & 72 \\
\hline 3 & 8 & 6 & 16 & 17 & 46 & 11 & 30 & 2.97 & $\begin{array}{l}37 \text { office } \\
\text { personnel }\end{array}$ & 2 & 5 & 13 & 35 & 22 & 60 \\
\hline 3 & 3 & 14 & 12 & 61 & 53 & 38 & 33 & 3.16 & 116 Total & 8 & 7 & 47 & 41 & 61 & 53 \\
\hline
\end{tabular}


TABLE 34

RESPONSES TO COMPETENCY 14: AUVOCATE (SPEAK FOR) THE STUDENTS WHEN APPROPRIAIE

\begin{tabular}{|c|c|c|c|c|c|c|c|c|c|c|c|c|c|c|c|}
\hline \multicolumn{8}{|c|}{ Essentiality } & \multicolumn{8}{|c|}{ Procedure } \\
\hline \multicolumn{2}{|c|}{$\begin{array}{l}\text { Not } \\
\text { important }\end{array}$} & \multicolumn{2}{|c|}{$\begin{array}{l}\text { Fairly } \\
\text { important }\end{array}$} & \multicolumn{2}{|c|}{$\begin{array}{l}\text { Moderately } \\
\text { important }\end{array}$} & \multicolumn{2}{|c|}{$\begin{array}{l}\text { Very } \\
\text { important }\end{array}$} & \multirow[t]{2}{*}{ Mean } & & \multicolumn{2}{|c|}{ Pre-service } & \multicolumn{2}{|c|}{ In-service } & \multicolumn{2}{|c|}{ Experience } \\
\hline No. & $\%$ & No. & $\%$ & No. & $\%$ & No. & $\%$ & & & No. & $\%$ & No. & $x$ & No. & $y$ \\
\hline 2 & 3 & 16 & 26 & 31 & 51 & 12 & 20 & 2.87 & 61 Principals & 1 & 2 & 11 & 18 & 49 & 80 \\
\hline 0 & 0 & 7 & 39 & 8 & 44 & 3 & 17 & 2.78 & 18 Inspectors & 1 & 6 & 3 & 16 & 14 & 78 \\
\hline 3 & 8 & 7 & 19 & 26 & 70 & 1 & 3 & 2.59 & $\begin{array}{l}37 \text { office } \\
\text { personnel }\end{array}$ & 3 & 8 & 11 & 30 & 23 & 62 \\
\hline 5 & 4 & 30 & 26 & 65 & 56 & 16 & 14 & 2.79 & 116 Total & 5 & 4 & 25 & 22 & 86 & 74 \\
\hline
\end{tabular}


TABLE 35

RESPONSES TO COMPETENCY 15: COMMUNICATE WITH STUDENTS

CONCERNING AL.L ASPECTS OF THEIR SCHOOL LIFE

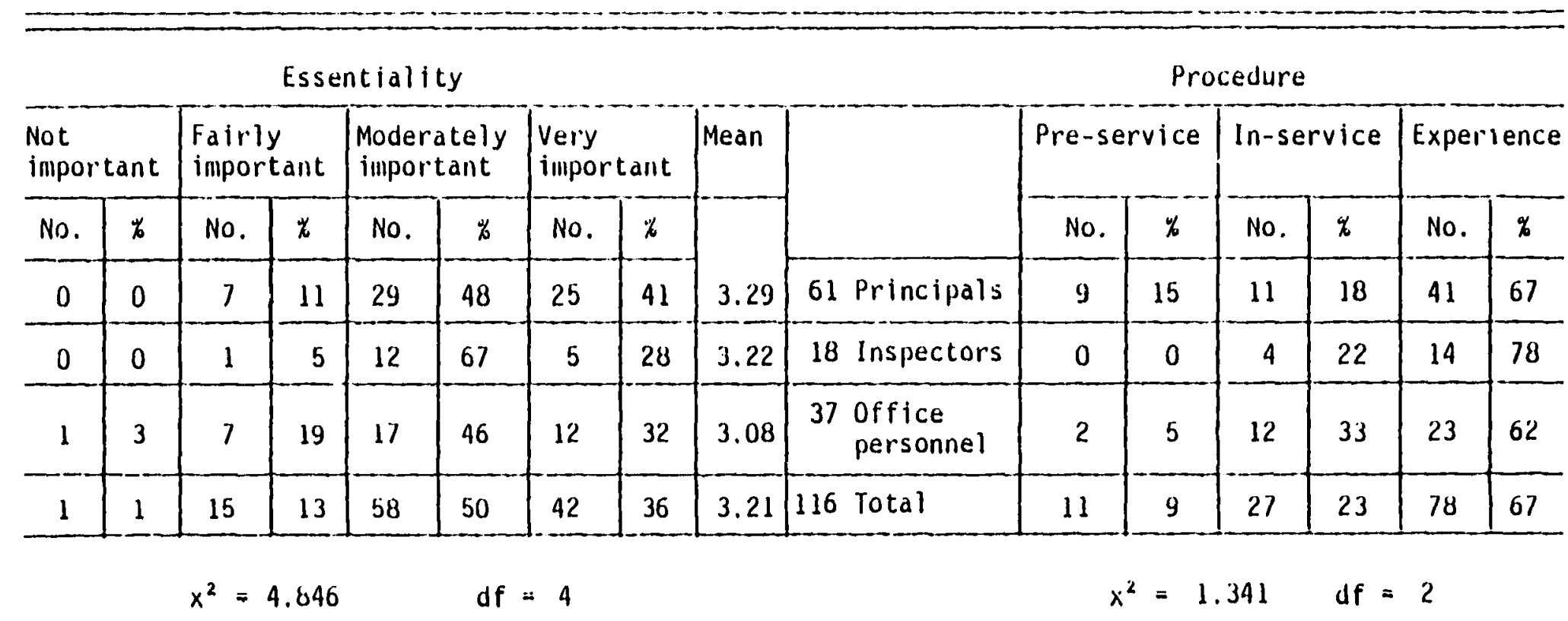


IABLE 36

RESPONSES TO COMPETENCY 16: ORGANIZE, COORUINATE, AND ADMINISTER TIIE TOTAL ACTIVITIES PROGRAM

\begin{tabular}{|c|c|c|c|c|c|c|c|c|c|c|c|c|c|c|c|}
\hline \multicolumn{10}{|c|}{ Essentiality } & \multicolumn{6}{|c|}{ Procedure } \\
\hline \multicolumn{2}{|c|}{$\begin{array}{l}\text { Not } \\
\text { important }\end{array}$} & \multicolumn{2}{|c|}{$\begin{array}{l}\text { Fairly } \\
\text { important }\end{array}$} & \multicolumn{2}{|c|}{$\begin{array}{l}\text { Moderately } \\
\text { important }\end{array}$} & \multicolumn{2}{|c|}{$\begin{array}{l}\text { Very } \\
\text { iniportant }\end{array}$} & \multirow[t]{2}{*}{ Mean } & & \multicolumn{2}{|c|}{ Pre-service } & \multicolumn{2}{|c|}{ In-service } & \multicolumn{2}{|c|}{ Experience } \\
\hline No. & $\%$ & No. & $\%$ & No. & $x$ & No. & $\%$ & & & Mo. & $\%$ & No. & $\%$ & No. & $\%$ \\
\hline 1 & 2 & 9 & 15 & 27 & 44 & 24 & 39 & 3.21 & 61 Principals & 22 & 36 & 26 & 43 & 13 & 21 \\
\hline 1 & 5 & 3 & 17 & 3 & 17 & 11 & 61 & 3.33 & 18 Inspectors & 10 & 56 & 5 & 28 & 3 & 17 \\
\hline 1 & 3 & 5 & 14 & 19 & 51 & 12 & 32 & 3.13 & $\begin{array}{l}\text { 3) Office } \\
\text { personnel }\end{array}$ & 5 & 14 & 20 & 54 & 12 & 32 \\
\hline 3 & 3 & 17 & 15 & 49 & 42 & 47 & 41 & 3.21 & 116 Total & 37 & 32 & 51 & 44 & 38 & 33 \\
\hline
\end{tabular}


TABLE. 37

RESPONSES TO COMPE TENCY 17: EVALUAIE IHE STUDENT ACTIVITILS PROGRAM

\begin{tabular}{|c|c|c|c|c|c|c|c|c|c|c|c|c|c|c|c|}
\hline \multicolumn{9}{|c|}{ Essentidilty } & \multicolumn{7}{|c|}{ Proceduris } \\
\hline \multicolumn{2}{|c|}{$\begin{array}{l}\text { Not } \\
\text { important }\end{array}$} & \multicolumn{2}{|c|}{$\begin{array}{l}\text { Fairly } \\
\text { important }\end{array}$} & \multicolumn{2}{|c|}{$\begin{array}{l}\text { Moderately } \\
\text { important }\end{array}$} & \multicolumn{2}{|c|}{$\begin{array}{l}\text { Very } \\
\text { important }\end{array}$} & \multirow[t]{2}{*}{ Mean } & & \multicolumn{2}{|c|}{ Pre-service } & \multicolumn{2}{|c|}{ In-service } & \multicolumn{2}{|c|}{ Experience } \\
\hline No. & $\%$ & No. & $\%$ & No. & $\%$ & No. & $x$ & & & No. & $\%$ & No. & $\%$ & No. & $x$ \\
\hline 2 & 3 & 5 & 8 & 34 & 56 & 20 & 33 & 3.13 & 61 Principals & 17 & 28 & 28 & 46 & 16 & $2 \epsilon$ \\
\hline 1 & 5 & 1 & 5 & 12 & 67 & 4 & 22 & 3.06 & 18 Inspectors & 5 & 28 & 5 & 28 & 8 & 44 \\
\hline 1 & 3 & 7 & 19 & 24 & 65 & 5 & 13 & 2.89 & $\begin{array}{l}37 \text { office } \\
\text { personnel }\end{array}$ & 3 & 8 & 26 & 70 & 8 & 22 \\
\hline 4 & 2 & 13 & 11 & 70 & 60 & 29 & 25 & 3.07 & 116 Total & 25 & 22 & 59 & 51 & 32 & 28 \\
\hline
\end{tabular}


RESPONSES TO COMPETENCY 18: MAINTAIN PARTICIPATION STANDARGS FOR STUUENT ACTIVITY PROGRAMS

\begin{tabular}{|c|c|c|c|c|c|c|c|c|c|c|c|c|c|c|c|}
\hline \multicolumn{10}{|c|}{ Essentiality } & \multicolumn{6}{|c|}{ Procedure } \\
\hline \multicolumn{2}{|c|}{$\begin{array}{l}\text { Not } \\
\text { important }\end{array}$} & \multicolumn{2}{|c|}{$\begin{array}{l}\text { Fairly } \\
\text { important }\end{array}$} & \multicolumn{2}{|c|}{$\begin{array}{l}\text { Moderately } \\
\text { important }\end{array}$} & \multicolumn{2}{|c|}{$\begin{array}{l}\text { Very } \\
\text { important }\end{array}$} & \multirow[t]{2}{*}{ Mean } & & \multicolumn{2}{|c|}{ Pre-service } & \multicolumn{2}{|c|}{ In-service } & \multicolumn{2}{|c|}{ Experience } \\
\hline No. & w & No. & $x$ & No. & $\%$ & No. & $x$ & & & No. & $\%$ & No. & $\%$ & No. & $y$ \\
\hline 0 & 0 & 10 & 16 & 33 & 54 & 18 & 30 & 3.13 & 61 Principals & 5 & 8 & 25 & 41 & 31 & 51 \\
\hline 1 & 5 & 1 & 5 & 14 & 78 & 2 & 11 & 2.94 & 18 Inspectors & 2 & 11 & 5 & 28 & 11 & 61 \\
\hline 1 & 3 & 19 & 49 & 13 & 35 & 4 & 14 & 2.46 & $\begin{array}{l}37 \text { Office } \\
\text { personnel }\end{array}$ & 1 & 3 & 16 & 43 & 20 & 54 \\
\hline 2 & 2 & 30 & 25 & 60 & 52 & 24 & 22 & 2.91 & 116 Total & 8 & 7 & 46 & 40 & $6 ?$ & 53 \\
\hline
\end{tabular}

$$
x^{2}=20.684 \quad d f=4
$$


TABLE 39

RESPONSES IO COMPETLNCY 19: MAINTAIN A PROGRAM OF SPECTATOR CONTROL AT ALL SCHOOL ACTIVITIES

\begin{tabular}{|c|c|c|c|c|c|c|c|c|c|c|c|c|c|c|c|}
\hline \multicolumn{10}{|c|}{ Essentiality } & \multicolumn{6}{|c|}{ Procedure } \\
\hline \multicolumn{2}{|c|}{$\begin{array}{l}\text { Not } \\
\text { important }\end{array}$} & \multicolumn{2}{|c|}{$\begin{array}{l}\text { Fairly } \\
\text { important }\end{array}$} & \multicolumn{2}{|c|}{$\begin{array}{l}\text { Moderately } \\
\text { important }\end{array}$} & \multicolumn{2}{|c|}{$\begin{array}{l}\text { Very } \\
\text { important }\end{array}$} & \multirow{3}{*}{\begin{tabular}{|l} 
Mean \\
2.83
\end{tabular}} & & \multicolumn{2}{|c|}{ Pre-service } & \multicolumn{2}{|c|}{ In-service } & \multicolumn{2}{|c|}{ Experience } \\
\hline No. & $\%$ & No. & $\%$ & No. & $\%$ & No. & $\%$ & & & No. & $\%$ & No. & $\%$ & No. & $x$ \\
\hline 2 & 3 & 15 & 25 & 35 & 57 & 9 & 15 & & 61 Principals & 2 & 3 & 12 & 20 & 47 & 77 \\
\hline 1 & 5 & 3 & 17 & 10 & 56 & 4 & 22 & 2.94 & 18 Inspectors & 1 & 5 & 5 & 28 & 12 & 67 \\
\hline 4 & 11 & 12 & 32 & 18 & 49 & 3 & 8 & 2.54 & $\begin{array}{l}\text { 37 Office } \\
\text { personnel }\end{array}$ & 3 & 8 & 13 & 35 & 21 & 57 \\
\hline 7 & 6 & 30 & 26 & 63 & 54 & 16 & 14 & 2.79 & 116 Total & 6 & 5 & 30 & 2.6 & 80 & 69 \\
\hline
\end{tabular}


TABLE 40

RESPUNSES IO COMPEIENCY 20: LSTABLISH

ATTENDANCE ACCOUNTING PROCEDURES

.

Essentiality

Procedure

\begin{tabular}{|c|c|c|c|c|c|c|c|c|c|c|c|c|c|c|c|}
\hline \multicolumn{2}{|c|}{$\begin{array}{l}\text { Not } \\
\text { important }\end{array}$} & \multicolumn{2}{|c|}{$\begin{array}{l}\text { Fairly } \\
\text { important }\end{array}$} & \multicolumn{2}{|c|}{$\begin{array}{l}\text { Moderately } \\
\text { important }\end{array}$} & \multicolumn{2}{|c|}{$\begin{array}{l}\text { Very } \\
\text { important }\end{array}$} & \multirow[t]{2}{*}{ Mean } & & \multicolumn{2}{|c|}{ Pre-service } & \multicolumn{2}{|c|}{ In-service } & \multicolumn{2}{|c|}{ Experience } \\
\hline No. & \% & No. & $\%$ & No. & $\%$ & No. & $\%$ & & & No. & $\%$ & No. & $x$ & No. & $x$ \\
\hline 1 & 2 & 8 & 13 & 15 & 24 & 37 & 61 & 3.44 & 61 Principals & 16 & 26 & 28 & 46 & 17 & 28 \\
\hline 0 & 0 & 1 & 6 & 8 & 44 & 9 & 50 & 3.39 & 18 Inspectors & 6 & 33 & 8 & 44 & 4 & 22 \\
\hline 3 & 8 & 6 & 16 & 6 & 16 & 22 & 59 & 3.27 & $\begin{array}{l}37 \text { Office } \\
\text { personnel }\end{array}$ & 11 & 30 & 19 & 51 & 7 & 19 \\
\hline 4 & 3 & 15 & 13 & 29 & 25 & 68 & 59 & 3.39 & 116 Total & 33 & 28 & 55 & 47 & 28 & 24 \\
\hline
\end{tabular}

$x^{2}=6.956 \quad d f=4$

$x^{2}=1.258 \quad d f=?$ 
TABLE 41

RESPUNSES TO COMPETENCY 21: ESTABLISII STUUENT CONTROL IND DISCIPLINARY PROCEDURES WITII THE ASSISTANCE

OF PARENTS, TEACHERS, AND STUDENTS

\begin{tabular}{|c|c|c|c|c|c|c|c|c|c|c|c|c|c|c|c|}
\hline \multicolumn{8}{|c|}{ Essentiality } & \multicolumn{8}{|c|}{ Procedure } \\
\hline \multicolumn{2}{|c|}{$\begin{array}{l}\text { Not } \\
\text { important }\end{array}$} & \multicolumn{2}{|c|}{$\begin{array}{l}\text { Fairly } \\
\text { important }\end{array}$} & \multicolumn{2}{|c|}{$\begin{array}{l}\text { Moderately } \\
\text { important }\end{array}$} & \multicolumn{2}{|c|}{$\begin{array}{l}\text { Very } \\
\text { important }\end{array}$} & \multirow[t]{2}{*}{ Mean } & & \multicolumn{2}{|c|}{ Pre-service } & \multicolumn{2}{|c|}{ In-service } & \multicolumn{2}{|c|}{ Experience } \\
\hline No. & $\%$ & No. & $x$ & No. & $x$ & No. & $\%$ & & & No. & $\%$ & No. & $\%$ & No. & $\%$ \\
\hline 2 & 3 & 4 & 7 & 9 & 15 & $46^{\circ}$ & 75 & 3.62 & 61 Principals & 8 & 13 & 18 & 30 & 35 & 57 \\
\hline 2 & 11 & 3 & 17 & 3 & 17 & 10 & 55 & 3.17 & 18 Inspectors & 9 & 50 & 1 & 6 & 8 & 44 \\
\hline 1 & 3 & 3 & 8 & 5 & 13 & 28 & 76 & 3.62 & $\begin{array}{l}37 \text { Office } \\
\text { personnel }\end{array}$ & 12 & 32 & 11 & 30 & 14 & 38 \\
\hline 5 & 4 & 10 & 9 & 17 & 15 & 84 & 72 & 3.55 & 116 Total & 29 & 25 & 39 & 26 & 57 & 49 \\
\hline
\end{tabular}


IABLE 42

RESPONSES TO COMPETLNCY 22: ORGANILE AND MANAGE A SCHOOL.

PROGRAM WIICH IMPLEMENIS THE SCHOOL PHILOSOPHY

\begin{tabular}{|c|c|c|c|c|c|c|c|c|c|c|c|c|c|c|c|}
\hline \multicolumn{9}{|c|}{ Essentiality } & \multicolumn{7}{|c|}{ Procedure } \\
\hline \multicolumn{2}{|c|}{$\begin{array}{l}\text { Not } \\
\text { important }\end{array}$} & \multicolumn{2}{|c|}{$\begin{array}{l}\text { Fairly } \\
\text { important }\end{array}$} & \multicolumn{2}{|c|}{$\begin{array}{l}\text { Moderately } \\
\text { important }\end{array}$} & \multicolumn{2}{|c|}{$\begin{array}{l}\text { Very } \\
\text { important }\end{array}$} & \multirow[t]{2}{*}{ Mean } & & \multicolumn{2}{|c|}{ Pre-service } & \multicolumn{2}{|c|}{ In-service } & \multicolumn{2}{|c|}{ Experience } \\
\hline No. & b & No. & $\%$ & No. & $\%$ & No. & $x$ & & & No. & $\%$ & No. & 4 & No. & $y$ \\
\hline 1 & 1 & 8 & 13 & 20 & 33 & 32 & 52 & 3.36 & 61 Principals & 22 & 36 & 25 & 41 & 14 & 23 \\
\hline 0 & 0 & 4 & 22 & 2 & 11 & 12 & 57 & 3.44 & 18 Inspectors & 9 & 50 & 7 & 39 & 2 & 11 \\
\hline 1 & 3 & 12 & 32 & 10 & 27 & 14 & 38 & 3.00 & $\begin{array}{l}37 \text { office } \\
\text { personnel }\end{array}$ & 10 & 27 & 16 & 43 & 11 & 20 \\
\hline 2 & 2 & 24 & 21 & 32 & 28 & 58 & 50 & 3.26 & 116 Totál & 41 & 35 & 48 & 41 & 27 & 23 \\
\hline
\end{tabular}

$$
x^{2}=8.810 \quad d f=4 \quad x^{2}=3.697 \quad d f=4
$$


TABLE 43

RESPONSES 10 COMPETENCY 23: SCHLUULE THE. SCHOOL ACADEMIC PROGRAM

\begin{tabular}{|c|c|c|c|c|c|c|c|c|c|c|c|c|c|c|c|}
\hline \multicolumn{10}{|c|}{ Essentiality } & \multicolumn{6}{|c|}{ Procedure } \\
\hline \multicolumn{2}{|c|}{$\begin{array}{l}\text { Not } \\
\text { important }\end{array}$} & \multicolumn{2}{|c|}{$\begin{array}{l}\text { Fairly } \\
\text { important }\end{array}$} & \multicolumn{2}{|c|}{$\begin{array}{l}\text { Moderately } \\
\text { important }\end{array}$} & \multicolumn{2}{|c|}{$\begin{array}{l}\text { Very } \\
\text { important }\end{array}$} & \multirow[t]{2}{*}{ Mean } & & \multicolumn{2}{|c|}{ Pre-service } & \multicolumn{2}{|c|}{ In-service } & \multicolumn{2}{|c|}{ Experience } \\
\hline No. & $\%$ & No. & $\%$ & Nos. & $\%$ & No. & $\%$ & & & No. & $\%$ & No. & z & No. & 4 \\
\hline 0 & 0 & 7 & 11 & 15 & 25 & 39 & 64 & 3.52 & 61 Principals & 8 & 13 & 41 & 67 & 12 & 20 \\
\hline 1 & 5 & 2 & 11 & 3 & 17 & 12 & 67 & 3.55 & 18 Inspectors & 8 & 45 & 6 & 33 & 4 & 22 \\
\hline 0 & 0 & 6 & 16 & 17 & 46 & 14 & 38 & 3.22 & $\begin{array}{l}37 \text { Office } \\
\text { personnel }\end{array}$ & 7 & 19 & 25 & 68 & 5 & 13 \\
\hline 1 & 1 & 15 & 13 & 35 & 30 & 65 & 56 & 3.41 & 116 Total & 23 & 20 & 72 & 62 & 21 & 18 \\
\hline
\end{tabular}


IABLE 44

RESHONSES IO COHPETENCY 24: MANAGE THE SCHOOL. PLANT FACILITIES

\begin{tabular}{|c|c|c|c|c|c|c|c|c|c|c|c|c|c|c|c|}
\hline \multicolumn{10}{|c|}{ Essentiality } & \multicolumn{6}{|c|}{ Procedure } \\
\hline \multicolumn{2}{|c|}{$\begin{array}{l}\text { Not } \\
\text { important }\end{array}$} & \multicolumn{2}{|c|}{$\begin{array}{l}\text { Fairly } \\
\text { important }\end{array}$} & \multicolumn{2}{|c|}{$\begin{array}{l}\text { Moderately } \\
\text { important }\end{array}$} & \multicolumn{2}{|c|}{$\begin{array}{l}\text { Very } \\
\text { important }\end{array}$} & \multirow[t]{2}{*}{ Mean } & & \multicolumn{2}{|c|}{ Pre-service } & \multicolumn{2}{|c|}{ In-service } & \multicolumn{2}{|c|}{ Experience } \\
\hline No. & $\%$ & No. & $\%$ & No. & $\%$ & No. & $\%$ & & & No. & $\%$ & No. & $\%$ & No. & $\%$ \\
\hline 1 & 2 & 6 & 10 & 28 & 46 & 26 & 42 & 3.30 & 61 Princifials & 7 & 11 & 31 & 51 & 23 & 38 \\
\hline 0 & 0 & 3 & 17 & 5 & 28 & 10 & 55 & 3.67 & 18 Inspectors & 3 & 17 & 1 & 39 & 8 & 44 \\
\hline 1 & 3 & 8 & 21 & 21 & 57 & 7 & 19 & 2.92 & $\begin{array}{l}37 \text { office } \\
\text { personnel }\end{array}$ & 6 & 16 & 18 & 49 & 13 & 35 \\
\hline 2 & 2 & 17 & 15 & 54 & 47 & 43 & 37 & 3.29 & 116 Total & 16 & 14 & 56 & 48 & 44 & 38 \\
\hline
\end{tabular}




\section{TABLLE 45}

RLSPONSES 10 COMPETENCY 25: OPERATE TIIE SCIOOL WITHIN THE FRAMEWORK OF THE LAW

\begin{tabular}{|c|c|c|c|c|c|c|c|c|c|c|c|c|c|c|c|}
\hline \multicolumn{8}{|c|}{ Essentiality } & \multicolumn{8}{|c|}{ Procedure } \\
\hline \multicolumn{2}{|c|}{$\begin{array}{l}\text { Not } \\
\text { important }\end{array}$} & \multicolumn{2}{|c|}{$\begin{array}{l}\text { Fairly } \\
\text { important }\end{array}$} & \multicolumn{2}{|c|}{$\begin{array}{l}\text { Moderately } \\
\text { important }\end{array}$} & \multicolumn{2}{|c|}{$\begin{array}{l}\text { Very } \\
\text { important }\end{array}$} & \multirow[t]{2}{*}{ Mean } & & \multicolumn{2}{|c|}{ Pre-service } & \multicolumn{2}{|c|}{ In-service } & \multicolumn{2}{|c|}{ Experience } \\
\hline No. & $\%$ & No. & $\%$ & No. & $\%$ & No. & $x$ & & & No. & $\%$ & No. & $q$ & No. & $\%$ \\
\hline 2 & 3 & 4 & 7 & 22 & 36 & 33 & 54 & 3.40 & 61 Principals & 6 & 10 & 33 & 54 & 22 & 36 \\
\hline 0 & 0 & 1 & 6 & 4 & 22 & 13 & 72 & 3.61 & 18 Inspectors & 6 & 33 & 6 & 33 & 6 & 33 \\
\hline 0 & 0 & 8 & 22 & 12 & 32 & 17 & 46 & 3.24 & $\begin{array}{l}\text { 3) Office } \\
\text { personnel }\end{array}$ & 6 & 16 & 16 & 43 & $1 b$ & 41 \\
\hline 2 & 2 & 13 & 11 & 38 & 33 & 68 & 59 & 3.57 & 116 Total & 18 & 16 & 55 & 47 & 43 & 37 \\
\hline
\end{tabular}


TABLE 46

RESPONSES TO COMPETENCY 26: ORGANIZE ANU MANAGE AUXILIARY SERVICES (CAFETERIA, TKANSPORTATION, HEALTH, AND SAFETY)

\begin{tabular}{|c|c|c|c|c|c|c|c|c|c|c|c|c|c|c|c|}
\hline \multicolumn{9}{|c|}{ Essentiality } & \multicolumn{7}{|c|}{ Procedure } \\
\hline \multicolumn{2}{|c|}{$\begin{array}{l}\text { Not } \\
\text { important }\end{array}$} & \multicolumn{2}{|c|}{$\begin{array}{l}\text { Fairly } \\
\text { important }\end{array}$} & \multicolumn{2}{|c|}{$\begin{array}{l}\text { Moderately } \\
\text { important }\end{array}$} & \multicolumn{2}{|c|}{$\begin{array}{l}\text { Very } \\
\text { important }\end{array}$} & \multirow[t]{2}{*}{ Mean } & & \multicolumn{2}{|c|}{ Pre-service } & \multicolumn{2}{|c|}{ In-service } & \multicolumn{2}{|c|}{ Experienc } \\
\hline No. & $\%$ & $\mathrm{No}$. & $\%$ & No. & $\%$ & No. & $\%$ & & & No. & $\%$ & No. & $\%$ & No. & $\%$ \\
\hline 2 & 3 & 15 & 25 & 28 & 46 & 16 & 26 & 2.95 & 61 Principals & 10 & 16 & 25 & 41 & 26 & 43 \\
\hline 1 & 6 & 8 & 44 & 6 & 33 & 3 & 17 & 2.61 & 18 Inspectors & 6 & 33 & 5 & 28 & 7 & 39 \\
\hline 0 & 0 & 8 & 24 & 19 & 51 & 8 & 22 & 2.92 & $\begin{array}{l}37 \text { Office } \\
\text { personnel }\end{array}$ & 3 & 8 & 21 & 57 & 13 & 35 \\
\hline 4 & 3 & 32 & 28 & 53 & 46 & 27 & 23 & 2.86 & 116 Total & 19 & 16 & 51 & 44 & 46 & 40 \\
\hline
\end{tabular}


TABLE 47

RESPONSES TO COMPETENCY 27: EVALUATE AUXILIARY SERVICES

\begin{tabular}{|c|c|c|c|c|c|c|c|c|c|c|c|c|c|c|c|}
\hline \multicolumn{10}{|c|}{ Essentiality } & \multicolumn{6}{|c|}{ Procedure } \\
\hline \multicolumn{2}{|c|}{$\begin{array}{l}\text { Not } \\
\text { important }\end{array}$} & \multicolumn{2}{|c|}{$\begin{array}{l}\text { Fairly } \\
\text { important }\end{array}$} & \multicolumn{2}{|c|}{$\begin{array}{l}\text { Moderately } \\
\text { important }\end{array}$} & \multicolumn{2}{|c|}{$\begin{array}{l}\text { Very } \\
\text { important }\end{array}$} & \multirow[t]{2}{*}{ Mean } & & \multicolumn{2}{|c|}{ Pre-service } & \multicolumn{2}{|c|}{ In-service } & \multicolumn{2}{|c|}{ Experience } \\
\hline No. & $x$ & No. & $\%$ & No. & $\%$ & No. & $\%$ & & & No. & $\%$ & No. & $\%$ & No. & $x$ \\
\hline 2 & 3 & 20 & 33 & 29 & 48 & 10 & 16 & 2.77 & 61 Principals & 7 & 11 & 24 & 39 & 30 & 49 \\
\hline 2 & 11 & 11 & 61 & 2 & 11 & 3 & 17 & 2.3 .3 & 18 Inspectors & 3 & 17 & 4 & 22 & 11 & 61 \\
\hline 1 & 3 & 18 & 48 & 14 & 38 & 4 & 11 & 2.51 & $\begin{array}{l}37 \text { office } \\
\text { personnel }\end{array}$ & 5 & 14 & 16 & 43 & 16 & 43 \\
\hline 5 & 4 & 49 & 42 & 45 & 39 & 17 & 15 & 2.63 & 116 Total & 15 & 13 & 44 & 38 & 57 & 49 \\
\hline
\end{tabular}


TABLE 48

RESPONSES TO COMPEIENCY 28: DEVELOP AND IMPROVE THE STAFF BY ATTRACTING AND RETAINING COMPETENT PERSONNEL

\begin{tabular}{|c|c|c|c|c|c|c|c|c|c|c|c|c|c|c|c|}
\hline \multicolumn{10}{|c|}{ Essentiality } & \multicolumn{6}{|c|}{ Procedure } \\
\hline \multicolumn{2}{|c|}{$\begin{array}{l}\text { Not } \\
\text { important }\end{array}$} & \multicolumn{2}{|c|}{$\begin{array}{l}\text { Fairly } \\
\text { important }\end{array}$} & \multicolumn{2}{|c|}{$\begin{array}{l}\text { Moderately } \\
\text { important }\end{array}$} & \multicolumn{2}{|c|}{$\begin{array}{l}\text { Very } \\
\text { important }\end{array}$} & \multirow[t]{2}{*}{ Mean } & & \multicolumn{2}{|c|}{ Pre-service } & \multicolumn{2}{|c|}{ In-service } & \multicolumn{2}{|c|}{ Experience } \\
\hline No. & $\%$ & No. & $\%$ & No. & $\%$ & No. & $\%$ & & & No. & $\%$ & No. & $x$ & No. & $x$ \\
\hline 1 & 2 & 8 & 13 & 18 & 29 & 34 & 56 & 3.39 & 61 Principals & 9 & 15 & 28 & 46 & 24 & 39 \\
\hline 0 & 0 & 2 & 11 & 5 & 28 & 11 & 61 & 3.50 & 18 Inspectors & 7 & 39 & 2 & 11 & 9 & 50 \\
\hline 1 & 3 & 4 & 11 & 11 & 30 & 21 & 56 & 3.40 & $\begin{array}{l}37 \text { office } \\
\text { personnel }\end{array}$ & 10 & 27 & 8 & 22 & 19 & 51 \\
\hline 2 & 2 & 14 & 12 & 34 & 29 & 66 & 57 & 3.41 & 116 Total & 26 & 22 & 38 & 33 & 52 & 45 \\
\hline
\end{tabular}


TABLE 49

RESPONSES TO COMPETENCY 29: ORGANILE, COORDINATE, AND SUPERVISE STAFF ASSIGNMENTS

\begin{tabular}{|c|c|c|c|c|c|c|c|c|c|c|c|c|c|c|c|}
\hline \multicolumn{9}{|c|}{ Essentiality } & \multicolumn{7}{|c|}{ Procedure } \\
\hline \multicolumn{2}{|c|}{$\begin{array}{l}\text { Not } \\
\text { important }\end{array}$} & \multicolumn{2}{|c|}{$\begin{array}{l}\text { Fairly } \\
\text { important }\end{array}$} & \multicolumn{2}{|c|}{$\begin{array}{l}\text { Moderately } \\
\text { important }\end{array}$} & \multicolumn{2}{|c|}{$\begin{array}{l}\text { Very } \\
\text { important }\end{array}$} & \multirow[t]{2}{*}{ Mean } & & \multicolumn{2}{|c|}{ Pre-service } & \multicolumn{2}{|c|}{ In-service } & \multicolumn{2}{|c|}{ Experience } \\
\hline No. & $\%$ & No. & $\%$ & No. & $\%$ & No. & $\%$ & & & No. & $\%$ & No. & $q$ & No. & $x$ \\
\hline 2 & 3 & 5 & 8 & 13 & 21 & 41 & 67 & 3.52 & 61 Principals & 7 & 11 & 31 & 51 & 23 & 38 \\
\hline 1 & 5 & 2 & 11 & 3 & 17 & 12 & 67 & 3.56 & 18 Inspectors & 6 & 33 & 5 & 28 & 7 & 39 \\
\hline 0 & 0 & 3 & 8 & 9 & 24 & 25 & 68 & 3.68 & $\begin{array}{l}37 \text { office } \\
\text { personnel }\end{array}$ & 8 & 22 & 15 & 40 & 14 & 38 \\
\hline 3 & 3 & 10 & 9 & 25 & 22 & 18 & 67 & 3.53 & 116 Total & 21 & 18 & 51 & 44 & 44 & 38 \\
\hline
\end{tabular}

$x^{2}=1.134 \quad d f=4 \quad x^{2}=5.868 \quad d f=4$ 
TABLE 50

RESPONSES TO COMPETENCY 30: ASSIST, ADVISE, COUNSEL, AND PROVIDE GUIDANCE TO THL: STAFF IN

THEIR PERSONAL AND SCIIOOL PROBLEMS

\begin{tabular}{|c|c|c|c|c|c|c|c|c|c|c|c|c|c|c|c|}
\hline \multicolumn{8}{|c|}{ Essentiality } & \multicolumn{8}{|c|}{ Procedure } \\
\hline \multicolumn{2}{|c|}{$\begin{array}{l}\text { Not } \\
\text { important }\end{array}$} & \multicolumn{2}{|c|}{$\begin{array}{l}\text { Fairly } \\
\text { important }\end{array}$} & \multicolumn{2}{|c|}{$\begin{array}{l}\text { Moderately } \\
\text { important }\end{array}$} & \multicolumn{2}{|c|}{$\begin{array}{l}\text { Very } \\
\text { important }\end{array}$} & \multirow[t]{2}{*}{ Mean } & & \multicolumn{2}{|c|}{ Pre-service } & \multicolumn{2}{|c|}{ In-service } & \multicolumn{2}{|c|}{ Experience } \\
\hline No. & $\psi$ & No. & $\%$ & No. & $\%$ & No. & $\%$ & & & No. & $\%$ & No. & $\%$ & No. & 4 \\
\hline 1 & 2 & 8 & 13 & 18 & 29 & 34 & 56 & 3.39 & 61 Principals & 5 & 8 & 25 & 41 & 31 & 51 \\
\hline 1 & 5 & 1 & 5 & 6 & 33 & 10 & 56 & 3.38 & 18 Inspectors & 4 & 22 & 3 & 17 & 11 & 61 \\
\hline 1 & 3 & 2 & 5 & 13 & 35 & 21 & 57 & 3.46 & $\begin{array}{l}\text { 37 Office } \\
\text { personnel }\end{array}$ & 7 & 19 & 17 & 46 & 13 & 35 \\
\hline 3 & 3 & 11 & 9 & 37 & 32 & 65 & 56 & 3.41 & 116 Total & 16 & 14 & 45 & 39 & 55 & 47 \\
\hline
\end{tabular}


$T A B \perp E 51$

RESPONSES TO COMPETENCY 31: IDENTIFY THE NEEDS

AND INTERESTS OF THE ENTIKE SCHOOL STAFF

\begin{tabular}{|c|c|c|c|c|c|c|c|c|c|c|c|c|c|c|c|}
\hline \multicolumn{9}{|c|}{ Essentiality } & \multicolumn{7}{|c|}{ Procedure } \\
\hline \multicolumn{2}{|c|}{$\begin{array}{l}\text { Not } \\
\text { important }\end{array}$} & \multicolumn{2}{|c|}{$\begin{array}{l}\text { Fairly } \\
\text { important }\end{array}$} & \multicolumn{2}{|c|}{$\begin{array}{l}\text { Moderately } \\
\text { important }\end{array}$} & \multicolumn{2}{|c|}{$\begin{array}{l}\text { Very } \\
\text { important }\end{array}$} & \multirow[t]{2}{*}{ Mean } & & \multicolumn{2}{|c|}{ Pre-service } & \multicolumn{2}{|c|}{ In-service } & \multicolumn{2}{|c|}{ Experience } \\
\hline No. & $\%$ & No. & $\%$ & No. & $\%$ & No. & $\%$ & & & No. & $\%$ & No. & $x$ & No. & $x$ \\
\hline 2 & 3 & 8 & 13 & 13 & 21 & 38 & 62 & 3.43 & 61 Principals & 8 & 13 & 24 & 39 & 30 & 48 \\
\hline 0 & 0 & 1 & 6 & 6 & 33 & 11 & 61 & 3.55 & 18 Inspectors & 5 & 28 & 3 & 17 & 10 & 56 \\
\hline 0 & 0 & 4 & 11 & 11 & 30 & 22 & 59 & 3.49 & $\begin{array}{l}37 \text { office } \\
\text { personnel }\end{array}$ & 5 & 13 & 8 & 22 & 24 & 65 \\
\hline 2 & 2 & 13 & 11 & 30 & 26 & 71 & 61 & 3.47 & 116 Total & 18 & 16 & 35 & 30 & 64 & 55 \\
\hline
\end{tabular}


TABLEE 52

RESPONSES TO COMPETENCY 32: FOSTER AND

MAINTAIN STAFF MORALE

\begin{tabular}{|c|c|c|c|c|c|c|c|c|c|c|c|c|c|c|c|}
\hline \multicolumn{10}{|c|}{ Essentiality } & \multicolumn{6}{|c|}{ Procedure } \\
\hline \multicolumn{2}{|c|}{$\begin{array}{l}\text { Not } \\
\text { important }\end{array}$} & \multicolumn{2}{|c|}{$\begin{array}{l}\text { Fairly } \\
\text { important }\end{array}$} & \multicolumn{2}{|c|}{$\begin{array}{l}\text { Moderately } \\
\text { important }\end{array}$} & \multicolumn{2}{|c|}{$\begin{array}{l}\text { Very } \\
\text { important }\end{array}$} & \multirow[t]{2}{*}{ Mean } & & \multicolumn{2}{|c|}{ Pre-service } & \multicolumn{2}{|c|}{ In-service } & \multicolumn{2}{|c|}{ Experience } \\
\hline No. & 4 & No. & $\%$ & No. & $\%$ & No. & $\%$ & & & No. & $\%$ & No. & $\psi$ & No. & $x$ \\
\hline 1 & 2 & 8 & 13 & 12 & 20 & 40 & 66 & 3.50 & 61 Principals & 7 & 11 & 11 & 18 & 43 & 70 \\
\hline 1 & 5 & 1 & 5 & 5 & 28 & 11 & 61 & 3.44 & 18 Inspectors & 4 & 22 & 7 & 39 & 7 & 39 \\
\hline 0 & 0 & 3 & 8 & 5 & 14 & 29 & 78 & 3.70 & $\begin{array}{l}37 \text { Office } \\
\text { personnel }\end{array}$ & 6 & 16 & 9 & 24 & 22 & 60 \\
\hline 2 & 2 & 12 & 10 & 22 & 19 & 80 & 69 & 3.55 & 116 Total & 17 & 15 & 27 & 23 & 72 & 62 \\
\hline
\end{tabular}


TABLE 53

RESPONSES TO COMPE IENCY 33: EVALUATE SCHOOL PERSONNEL

\begin{tabular}{|c|c|c|c|c|c|c|c|c|c|c|c|c|c|c|c|}
\hline \multicolumn{8}{|c|}{ Essentiality } & \multicolumn{8}{|c|}{ Procedure } \\
\hline \multicolumn{2}{|c|}{$\begin{array}{l}\text { Not } \\
\text { important }\end{array}$} & \multicolumn{2}{|c|}{$\begin{array}{l}\text { Fairly } \\
\text { important }\end{array}$} & \multicolumn{2}{|c|}{$\begin{array}{l}\text { Moderately } \\
\text { important }\end{array}$} & \multicolumn{2}{|c|}{$\begin{array}{l}\text { Very } \\
\text { important }\end{array}$} & \multirow[t]{2}{*}{ Mran } & & \multicolumn{2}{|c|}{ Pre-service } & \multicolumn{2}{|c|}{ In-service } & \multicolumn{2}{|c|}{ Experience } \\
\hline No. & $\%$ & No. & $\%$ & No. & $\%$ & No. & $\%$ & & & No. & $\%$ & No. & $\%$ & No. & $\%$ \\
\hline 0 & 0 & 8 & 13 & 33 & 54 & 20 & 33 & 3.20 & 61 Principals & 15 & 25 & 33 & 54 & 13 & 21 \\
\hline 0 & 0 & 0 & 0 & 11 & 61 & 7 & 39 & 3.39 & 181 ipectors & 5 & 28 & 5 & 28 & 8 & 44 \\
\hline 1 & 3 & 5 & 13 & 18 & 49 & 13 & 35 & 3.16 & $\begin{array}{l}37 \text { Office } \\
\text { personnel }\end{array}$ & 14 & 38 & 18 & 49 & 5 & 13 \\
\hline 1 & 1 & 13 & 11 & 63 & 54 & 40 & 34 & 3.24 & 116 Total & 34 & 29 & 56 & 48 & 26 & 22 \\
\hline
\end{tabular}


IABLE 54

RESPONSES TO COMPEIENCY 34: KLEP IEACIIERS ABREASI

OF CURRENT EDUCATIONA! IMPROVEMENTS

\begin{tabular}{|c|c|c|c|c|c|c|c|c|c|c|c|c|c|c|c|}
\hline \multicolumn{9}{|c|}{ Essentiality } & \multicolumn{7}{|c|}{ Procedure } \\
\hline \multicolumn{2}{|c|}{$\begin{array}{l}\text { Not } \\
\text { important }\end{array}$} & \multicolumn{2}{|c|}{$\begin{array}{l}\text { Fairly } \\
\text { important }\end{array}$} & \multicolumn{2}{|c|}{$\begin{array}{l}\text { Moderately } \\
\text { inportant }\end{array}$} & \multicolumn{2}{|c|}{$\begin{array}{l}\text { Very } \\
\text { illiportant }\end{array}$} & \multirow[t]{2}{*}{ Mean } & & \multicolumn{2}{|c|}{ Pre-service } & \multicolumn{2}{|c|}{ In-service } & \multicolumn{2}{|c|}{ Experience } \\
\hline No. & $\%$ & No. & $\%$ & No. & $\%$ & No. & $x$ & & & No. & $\%$ & No. & $\%$ & No. & $\psi$ \\
\hline 1 & 2 & 8 & 13 & 20 & 33 & 32 & 52 & 2.70 & 61 Principals & 5 & 8 & 38 & 62 & 18 & 30 \\
\hline 0 & 0 & 2 & 11 & 6 & 33 & 10 & 56 & 3.44 & 18 Inspectors & 3 & 17 & 10 & 55 & 5 & 28 \\
\hline 1 & 3 & 6 & 16 & 18 & 49 & 12 & 32 & 3.11 & $\begin{array}{l}37 \text { Office } \\
\text { personnel }\end{array}$ & 7 & 19 & 19 & 51 & 11 & 30 \\
\hline 2 & 2 & 16 & 14 & 44 & 38 & 54 & 41 & 3.29 & 116 Total & 15 & 13 & 67 & 58 & 34 & 29 \\
\hline
\end{tabular}


IABLE SS

RESPONSES TO COMPETENCY 35: ENCOURAGE TEACIERS TO PRACTISE CREATIVE ANU INNOVATIVE TECINIQUES

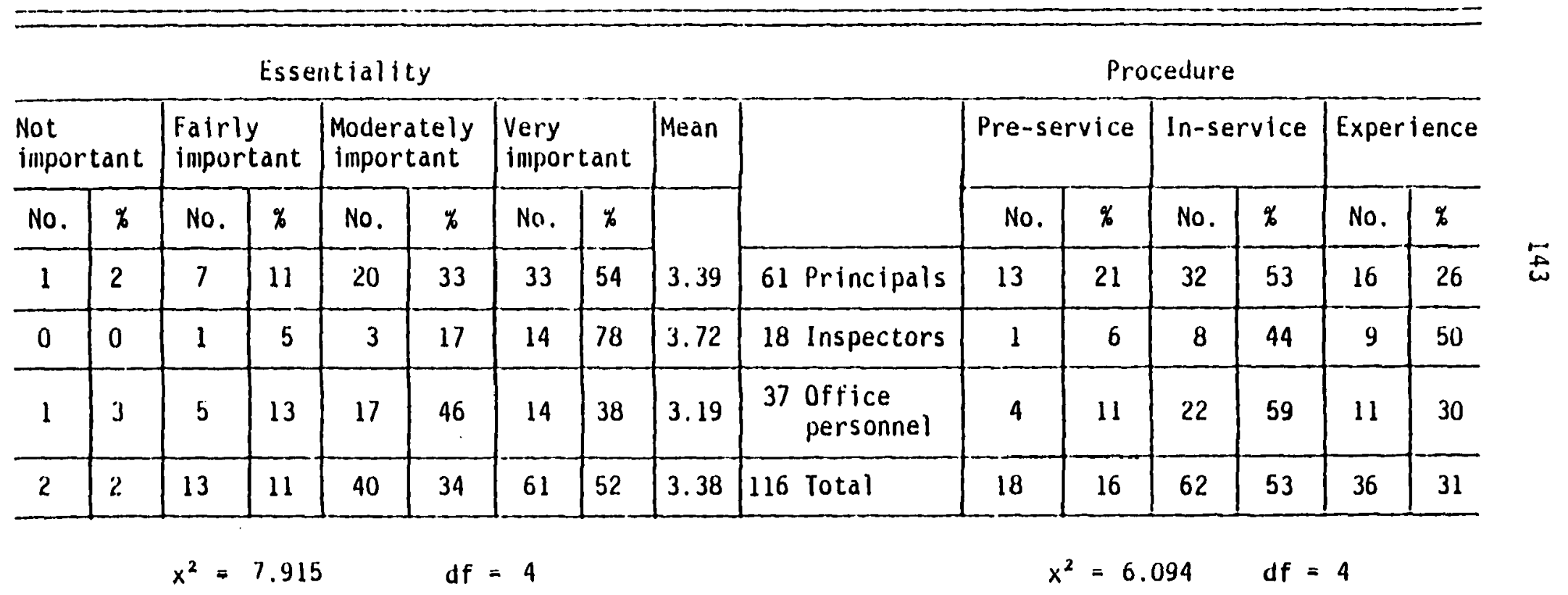




\section{TABLE: 56}

RESPONSES 10 COMPETENCY 36: INVOLVE IIIE SCHUOL STAFF IN THE DEVELOPMENT AND RE-EVALUATION OF EDUCATIONAL GOALS AND OBJECTIVES

.

Procedure

\begin{tabular}{|c|c|c|c|c|c|c|c|c|c|c|c|c|c|c|c|}
\hline \multicolumn{2}{|c|}{$\begin{array}{l}\text { Not } \\
\text { important }\end{array}$} & \multicolumn{2}{|c|}{$\begin{array}{l}\text { Fairly } \\
\text { important }\end{array}$} & \multicolumn{2}{|c|}{$\begin{array}{l}\text { Moderately } \\
\text { important }\end{array}$} & \multicolumn{2}{|c|}{$\begin{array}{l}\text { Very } \\
\text { iliportant }\end{array}$} & \multirow[t]{2}{*}{ Mean } & & \multicolumn{2}{|c|}{ Pre-service } & \multicolumn{2}{|c|}{ In-service } & \multicolumn{2}{|c|}{ Experience } \\
\hline No. & $\%$ & No. & $\%$ & No. & $\%$ & No. & 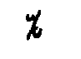 & & & No. & $\%$ & No. & $\%$ & No. & $\%$ \\
\hline 2 & 3 & 7 & 11 & 22 & 36 & 30 & 49 & 3.31 & 61 Principals & 6 & 10 & 35 & 57 & 20 & 33 \\
\hline 0 & 0 & 1 & 5 & 7 & 39 & 10 & 56 & 3.50 & 18 Inspitctors & 1 & 6 & 9 & 50 & 8 & 44 \\
\hline 1 & 3 & 6 & 16 & 11 & 30 & 19 & 51 & 3.30 & $\begin{array}{l}37 \text { Office } \\
\text { persionnel }\end{array}$ & 8 & 22 & 19 & 51 & 10 & 27 \\
\hline 3 & 3 & 14 & 12 & 40 & 34 & 59 & 51 & 3.34 & 116 Total & 15 & 13 & 53 & 46 & 38 & 33 \\
\hline
\end{tabular}


TABLE 57

RESPONSES TO COMPETENCY 37: PLAN AND EVALUATE THE

INSTRUITIONAL AND CURRICULAR PROGRAMS WITII TIIE

ASSISTANCE OF TEACHERS, AND STUDENTS

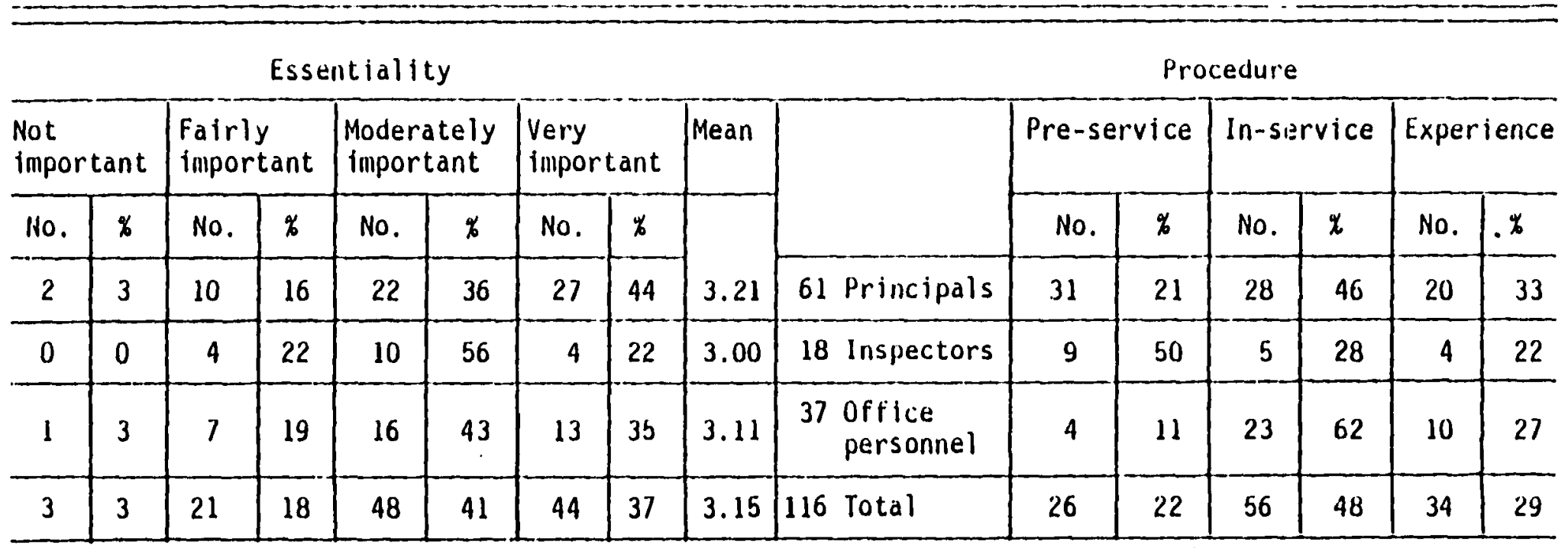

$$
x^{2}=3.280 \quad d f=4 \quad x^{2}=12.109 \quad d f=4
$$


TABLE 58

RESPONSES TO COMPETENCY 38: ASSESS PROGRAM NEEDS INVOIVING TEACIIERS, AND STUDENTS

\begin{tabular}{|c|c|c|c|c|c|c|c|c|c|c|c|c|c|c|c|}
\hline \multicolumn{9}{|c|}{ Essentiality } & \multicolumn{7}{|c|}{ Procedure } \\
\hline \multicolumn{2}{|c|}{$\begin{array}{l}\text { Not } \\
\text { important }\end{array}$} & \multicolumn{2}{|c|}{$\begin{array}{l}\text { Fairly } \\
\text { important }\end{array}$} & \multicolumn{2}{|c|}{$\begin{array}{l}\text { Moderately } \\
\text { important }\end{array}$} & \multicolumn{2}{|c|}{$\begin{array}{l}\text { Very } \\
\text { ilmportant }\end{array}$} & \multirow[t]{2}{*}{ Mean } & & \multicolumn{2}{|c|}{ Pre-service } & \multicolumn{2}{|c|}{ In-service } & \multicolumn{2}{|c|}{ Experience } \\
\hline No. & $x$ & No. & $\%$ & No. & $\%$ & No. & $\%$ & & & No. & $\%$ & No. & $\%$ & Mo. & $\%$ \\
\hline 1 & 2 & 15 & 25 & 24 & 39 & 21 & 34 & 3.07 & 61 Principals & 5 & 8 & 35 & 37 & 21 & 35 \\
\hline 0 & 0 & 1 & 6 & 13 & 72 & 4 & 22 & 3.11 & 18 Inspectors & 4 & 22 & 5 & 28 & 9 & 50 \\
\hline 2 & 5 & 8 & 22 & 17 & 46 & 10 & 27 & 2.95 & $\begin{array}{l}37 \text { Office } \\
\text { personnel }\end{array}$ & 6 & 16 & 16 & 43 & 15 & 41 \\
\hline 3 & 3 & 24 & 21 & 53 & 46 & 35 & 30 & 3.01 & 116 Total & 15 & 13 & 56 & 48 & 45 & 39 \\
\hline
\end{tabular}


TABLE 59

RESPONSES TO COMPETENCY 39: PRUVIDE CURRICULAR

AND INSTRUCTIONAL LEADERSIIIP

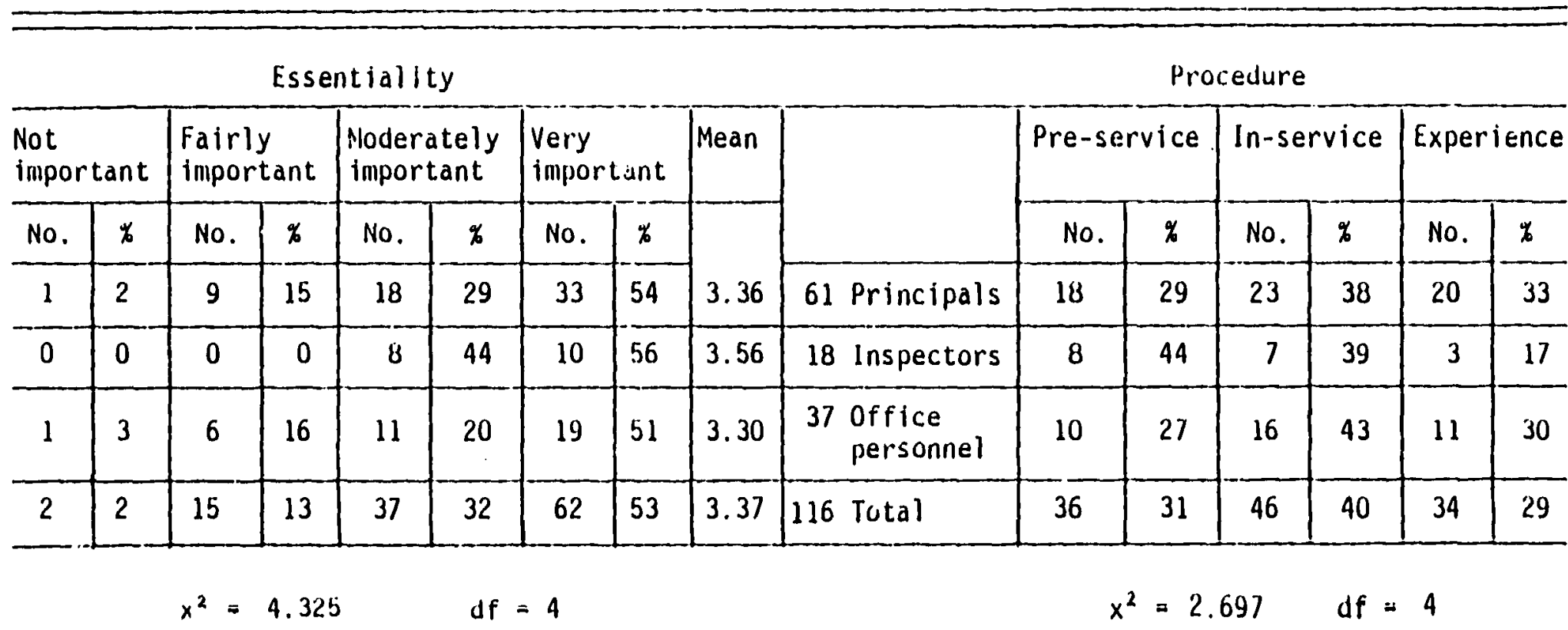


TABLE 60

RESPONSES TO CUMPETENCY 40: SUPERVISE AND COORUINAIE EUUCATIONAL PROGRAMS AND EXPERIENCES

\begin{tabular}{|c|c|c|c|c|c|c|c|c|c|c|c|c|c|c|c|}
\hline \multicolumn{8}{|c|}{ Essentiality } & \multicolumn{8}{|c|}{ Procedure } \\
\hline \multicolumn{2}{|c|}{$\begin{array}{l}\text { Not } \\
\text { important }\end{array}$} & \multicolumn{2}{|c|}{$\begin{array}{l}\text { Fairly } \\
\text { important }\end{array}$} & \multicolumn{2}{|c|}{$\begin{array}{l}\text { Moderately } \\
\text { important }\end{array}$} & \multicolumn{2}{|c|}{$\begin{array}{l}\text { Very } \\
\text { iniportant }\end{array}$} & \multirow[t]{2}{*}{ Mean } & & \multicolumn{2}{|c|}{ Pre-service } & \multicolumn{2}{|c|}{ In-service } & \multicolumn{2}{|c|}{ Experience } \\
\hline No. & $\%$ & No. & $\%$ & No. & $\%$ & No. & $\%$ & & & No. & $\%$ & No. & $\%$ & No. & 6 \\
\hline 2 & 3 & 8 & 13 & 28 & 46 & 23 & 38 & 3.18 & 61 P incipals & 6 & 10 & 33 & 54 & 22 & 36 \\
\hline 1 & 5 & 1 & 5 & 5 & 28 & 11 & 61 & 3.44 & 18 Inspectors & 5 & 28 & 6 & 33 & 7 & 39 \\
\hline 0 & 0 & 5 & 13 & 14 & 38 & 18 & 49 & 3.35 & $\begin{array}{l}37 \text { Office } \\
\text { personnel }\end{array}$ & 4 & 11 & 23 & 62 & 10 & 27 \\
\hline 3 & 3 & 14 & 12 & 47 & 15 & 52 & 45 & 3.28 & 116 Total & 15 & 13 & 62 & 53 & 39 & 34 \\
\hline
\end{tabular}


TABIE 61

RESPONSES TO COMPETENCY 41: EMPLOY PROFESSIUNAL RESEARCII IECINIQUES AND FINDINGS IN THE SOLUTION

OF EDUCATIONAL PROBI.EMS

\begin{tabular}{|c|c|c|c|c|c|c|c|c|c|c|c|c|c|c|c|}
\hline \multicolumn{8}{|c|}{ Essentiality } & \multicolumn{8}{|c|}{ Procedure } \\
\hline \multicolumn{2}{|c|}{$\begin{array}{l}\text { Not } \\
\text { important }\end{array}$} & \multicolumn{2}{|c|}{$\begin{array}{l}\text { Fairly } \\
\text { important }\end{array}$} & \multicolumn{2}{|c|}{$\begin{array}{l}\text { Moderately } \\
\text { important }\end{array}$} & \multicolumn{2}{|c|}{$\begin{array}{l}\text { Very } \\
\text { important }\end{array}$} & \multirow[t]{2}{*}{ Mean } & & \multicolumn{2}{|c|}{ Pre-service } & \multicolumn{2}{|c|}{ In-service } & \multicolumn{2}{|c|}{ Experience } \\
\hline No. & $\%$ & No. & $\%$ & No. & $\%$ & No. & $\%$ & & & No. & $\%$ & No. & $x$ & No. & $\%$ \\
\hline 5 & $\theta$ & 14 & 23 & 29 & 48 & 13 & 21 & 2.82 & 61 Principals & 17 & 28 & 30 & 49 & 14 & 23 \\
\hline 0 & 0 & 6 & 33 & 6 & 33 & 6 & 33 & 3.00 & 18 Inspectors & 9 & 50 & 5 & 28 & 4 & 22 \\
\hline 4 & 11 & 11 & 30 & 18 & 49 & 4 & 11 & 2.59 & $\begin{array}{l}37 \text { office } \\
\text { personnel }\end{array}$ & 8 & 22 & 12 & 32 & 17 & 46 \\
\hline 9 & 8 & 31 & 27 & 53 & 45 & 23 & 20 & 2.78 & 116 Total & 34 & 29 & 37 & 32 & 35 & 30 \\
\hline
\end{tabular}




\section{TABLE 62}

RESPONSES TO COMPETENCY 42: INITIAIE LONG-RANGE PLANNING PROCEDURE INVOL.VING TEACHERS AND STUDENTS

\begin{tabular}{|c|c|c|c|c|c|c|c|c|c|c|c|c|c|c|c|}
\hline \multicolumn{10}{|c|}{ Essentrality } & \multicolumn{6}{|c|}{ Procedure } \\
\hline \multicolumn{2}{|c|}{$\begin{array}{l}\text { Not } \\
\text { important }\end{array}$} & \multicolumn{2}{|c|}{$\begin{array}{l}\text { Fairly } \\
\text { important }\end{array}$} & \multicolumn{2}{|c|}{$\begin{array}{l}\text { Moderately } \\
\text { important }\end{array}$} & \multicolumn{2}{|c|}{$\begin{array}{l}\text { Very } \\
\text { important }\end{array}$} & \multirow[t]{2}{*}{ Mean } & & \multicolumn{2}{|c|}{ Pre-service } & \multicolumn{2}{|c|}{ In-service } & \multicolumn{2}{|c|}{ Experience } \\
\hline No. & $\%$ & No. & $x$ & No. & \% & No. & $\%$ & & & No. & $\%$ & No. & $\%$ & No. & $\%$ \\
\hline 3 & 5 & 10 & 16 & 28 & 46 & 20 & 33 & 3.07 & 61 Principals & 8 & 13 & 27 & 44 & 26 & 43 \\
\hline 0 & 0 & 4 & 22 & 9 & 50 & 5 & 28 & 3.56 & 18 Inspectors & 2 & 11 & 7 & 39 & 9 & 50 \\
\hline 1 & 3 & 15 & 41 & 12 & 32 & 9 & 24 & 2.78 & $\begin{array}{l}37 \text { of fice } \\
\text { personnel }\end{array}$ & 6 & 16 & 14 & 38 & 17 & 46 \\
\hline 4 & 3 & 29 & 25 & 49 & 42 & 34 & 29 & 2.97 & 116 Total & 16 & 14 & 48 & 41 & 52 & 45 \\
\hline
\end{tabular}


IABI.E 63

RESPONSES 10 COMPETENCY 43: INITIATE AND ENCOURAGE PROFESSIONAL RESEARCII

\begin{tabular}{|c|c|c|c|c|c|c|c|c|c|c|c|c|c|c|c|}
\hline \multicolumn{8}{|c|}{ Essentiality } & \multicolumn{8}{|c|}{ Procedure } \\
\hline \multicolumn{2}{|c|}{$\begin{array}{l}\text { Not } \\
\text { important }\end{array}$} & \multicolumn{2}{|c|}{$\begin{array}{l}\text { Fairly } \\
\text { important }\end{array}$} & \multicolumn{2}{|c|}{$\begin{array}{l}\text { Moderately } \\
\text { important }\end{array}$} & \multicolumn{2}{|c|}{$\begin{array}{l}\text { Very } \\
\text { important }\end{array}$} & \multirow[t]{2}{*}{ Mean } & & \multicolumn{2}{|c|}{ Pre-service } & \multicolumn{2}{|c|}{ In-service } & \multicolumn{2}{|c|}{ Experience } \\
\hline No. & $\%$ & No. & $x$ & No. & $\%$ & No. & $\%$ & & & No. & $q$ & No. & $x$ & No. & $\%$ \\
\hline 5 & 8 & 19 & 31 & 26 & 43 & 11 & 18 & 2.70 & 6l Principals & 5 & 8 & 25 & 41 & 31 & 51 \\
\hline 1 & 5 & 4 & 22 & 10 & 56 & 3 & 17 & 2.83 & 18 Inspectors & 3 & 17 & 6 & 3.3 & 9 & 50 \\
\hline 6 & 16 & 12 & 32 & 16 & 43 & 3 & 8 & 2.59 & $\begin{array}{l}37 \text { Office } \\
\text { personnel }\end{array}$ & 7 & 19 & 17 & 46 & 13 & 35 \\
\hline 12 & 10 & 35 & 30 & 52 & 45 & 17 & 15 & 2.64 & 116 Total & 15 & 13 & 58 & 50 & 53 & 46 \\
\hline
\end{tabular}

$$
x^{2}=3.501 \quad d f=4 \quad x^{2}=4.075 \quad d f=4
$$




\section{IBLIOGRAPHY}

dustin, Joe. "The Necessary Job Competencies of Secondary School Principals as Perceived by Selected Texas Educators."

Ed.D. dissertation, indiana University, 1973.

Bhandari, S. C. "Effective Administration and Organization of Schools." journal of Kementerian Pelajaran 54 (April 1976):16-17.

Borich, Gary 0. Three School-based Models for Conducting Follow-up Studies of Teacher Education and Training. Austin: Research and Development Center for Teacher Education, 1977 (ERIC Document, ED 152 693).

Burgess, Philip M. and Associates. Strengthening the Leadership and Management Capabilities of the Princiaplship. Columbus:

Varshon Center, Ohio State University, 1975.

Burnham, Ray Glendel1. "The Functions of High School Principals as Furceived by Superintendents, School Board Presidents, and High School Principais in Louisiana." Ph.D. dissertation, Auburn University, 1978.

Cannon, Mark $w$. "The Critical Role of Principals in Strengthening Society's Value System." National Association of Secondary School Principals Bulletin 65 (November 1981):76-78.

Castetter, William B. The Personnel Function of Educational Administration. New York: MacMillan Publishing Co., 1981.

Chaffee, H. Clifford, and Sloan, Charles A. "Clinical Experiences and Preparation of School Administrators." ERIC Document, ED $195 \mathrm{~J} 21,1900$.

Coriley, Gail. "A Study of Administrative Competencies ior Beginning School Principals in Northern Illinois." Ph.D. dissertation, Northern III inois University, 1976.

Cook, Haisy Hammond, and Van Otten, K. P. "A Study of the Prime Competencies Required to Perform the Tasks of the Secondary School Principals." Fh.J. dissertation, University of Utan, 1972.

Cunningham, Luvern L. "The Principal in the Learning Community." National Elementary Principal 53 (July-August, 1974):42. 
Jepartment of Education. Penyata Tahunan. Sabah: Kinabalu Printing Sdn., 1977.

Ellett, Chad O. Resuit Oriented Management in Education. Project R.O.M.E. Final Report, Volume 1. Atlanta: Georgia State Department of Edication, 1976 (ERIC Document, ED 131590 ).

Fater, Charles F., and Shearron, Gilbert F. Elementary School Administration: Theory and Practice. New York: Hoit, Rinehart, and Winston, 1970.

Farquhar, Robin H., and Martin, W. Michael. "New Developments in the Preparation of Educational Leaders." Phi Delta Kappa 56 (September 1972):26-27.

Geering, Adrian Douglas. "A Study of Behaviors, Competencies, and in-service Needs of Principals as Perceived by Principals, Central Office Staff and Teachers." Ph.D. dissertation, University of Nebraska, 1980.

Hansen, J. Merrell. "Why In-service? An Obligation of Schools to Provide the Best." National Association of Secondary School Principals Bulletin 64 (December 1980):67-82.

Harris, Ben M.; McIntyre, Kennetn E.; Littleton, Vance E.; and Long, Daniel $F$. Personnel Administration in Education. Boston: Allyn and Bacon Inc., 1979.

Hemphill, John K. "Report of the Senior High School Principalship." National Association of Secondary School Principals Bulletin 49 (January 1965):149.

Houston, W. Robert. Exploring Competency-based Education. Cal ifornia: MaCutchan Publishing Company, 1974.

Houston, W. Robert, and Warner, Allen R. "The Competency-based Movement: Origins and Future." Educational Technology 17 (June 1977): 14-15.

Katz, Robert L. "Skills of an Effective Administrator." Harvard Business Review 33 (January-February 1955):33-42.

Lawrence, Jack $P$. "The Development of a Source Book of Suggested Competencies and Activities for Interns in Secondary Administration." Ph.D. dissertation, University of Maryland, 1958 .

Lyons, James E. "A Study of Competencies Needte Sy Rejinnin.j Socondary Principals." Ph.D. disseriation, Ohio Stäte University, 1978. 
Martin, Evelyn B. "Programs for the Principals." National Associazion of Secondary School Principal's Bulletin 57 (March 1973): 70-73.

McCabe, Jennis P., and Compton, Jack. Role Acquisition and Competency Development of Educational Administrators in the Lower Rio Grande Valley. Texas: Pan American University, 1974 (ERIC Document, ED 130383 ).

MCCleary, Lloyd E., and McIntyre, Kenneth E. "Competency Deveiopment and University Methodology--A Model and Proposal." National Association of Secondary School Principal's Bulletin 56 (March 1972):53-59.

McDavid, J. Russel1. "Principals' Perceptions Regarding the Preservice Preparation of Beginning Secondary School Principals." Ed.D. dissertation, Indiana University, 1973.

Milne, R. S., and Ratnan, K. $\checkmark$. Malaysia--New States in a New Nation. London: Frank Cass and Company, 1374.

Nong, Yaacob Bin. "The Relevancy of Performance-based Teacher Education to Malaysian Teacner Preparation Program." Ph.O. dissertation, United States International University, 1977.

Paddock, Susan C. "The Principal and the Community: Competencies to Meet the Challenge." National Association of Secondary School Principal's Bulletin 65 (February 1981):63-67.

Rassmussen, G. R., and Hughes, L. 'N. "Simulation: It's the Real Thing." National Association of Secondary School Principal's bulietin 56 (March $19 / 2): 16-81$.

Reed, Rodney j. School Principal: Leader or Manager. ERIC Document, ED $145518,1977$.

Rosner, Benjamin, and Kay, Patricia. "Nill the Promise of C/PBTE be Fulfilled?" Phi Delta Kappan 55 (January 1974):290-297.

Sabah Times. Kota Kinabalu, December 23, 1969.

. Kota Kinabalu, August 5, 1970.

Schmieder, Allan A. "Competency-based Education: The State of the Scene." American Association of Colleges for Teacher Education 53 (February 1973):3-4.

Slate, Virginia S. "A Program to Train the Middle School Principal." Vational Association of Secondary School Principai s Builetin j9 (November 1975):75 
Sweitzer, Robert E. Role Expectation and Perception of School Principals. Vorman: Research Foundation, Oklahoma State University, 1963.

Taha, Hasbullah Muhammad. "The Perceptions of Educational Leaders in the State of Saban, Malaysia, Concerning Teacher Education." Ph.D. dissertation, Southern IIlinois University at Carbondale, 1979 .

Treblas, John P. "Priorities of Competencies in Educational Adminiscration as Perceived by Superintendents of Puilic Schools." Ed.D. dissertation, Colorado State College, 1966.

Trump, ง. Lloyd. "Principal Most Potent Factor in Determining School Excellence." Vational Association of Secondary School Principal's Bulletin 56 (March 1972):3-6.

Trump, John M. "The Instructional Leadership Roie of the High School Principal." American Secondary Education 11 (Summer 1981): 2-4.

United Nations Educational, Scientific, and Cultural Organization (Thailand). The Training of Educational Personnel. Report of a Regional Seminar. Thailand: UNESCO, 1979 (ERIC Jocument, ED 193 169).

- Planning and Programing for the Third Cycle of APEID: A Framework. Report of a Study Group Meeting. Thailand: UNESCO, 1980 (ERIC Document, ED 194289 ).

Ireeland, Nena and others. Area Handbook for Malaysia. Washington, O.C.: U.S. Gevernment Printing Office, 1977.

Nalters, Dona id L. Perceptions of Administrative Competencies: $A$ Survey of School Principals and Administrators. ERIC Docunent, ED 172361,1979 .

Weihnacht, Melissa Freeland. "Competencies of High School Principals Analyzed within the Eramework of a Survey and the Literature on Educational Futurism." Ph.D. dissertation, University of Florida, 1974.

Weldy, Gilbert. "It's a Bird! It's a Plane! It's Super-principal!" The Clearing House 52 (April 1979):194-197.

Nes tbrook, Douglas C., and Sandefur, Walter. "Involvement of AACTE Institutions in CBTE Programs." Phi Delta Kappan 57 (December 1975):276-277.

Witbur, Eugene Philip. "Components of Administrative Competence as Determined by Secondary Principals." Ph.D. dissertation, University of Oregon, 1973. 
Noodward, Prince B. "A Study of the Competencies Needed by School Administrators and Supervisors, with Implications for Preservice Education." Ed.D. dissertation, University of Virginia, 1954.

Zechman, Harry T. "Are Principals Competent in instructional Leadership Domain." Vational Association of Secondary School Principal's Bulletin ól (December 1977):21-25. 
VAME: Charles S. Gaban

DATE CF BIRTH: September 1, 1937

PLACE OF BIRTH: Sabah, Malaysia

EDUCATION:

1971 Bachelor of Arts - History

Philippine Union College

ilanila, Philippines

1973 Master of Arts - Educational Administration

Philippine Union College

Manila, Philippines

1981 Master of Business Administration

Andrews University

1982 Doctor of Education - Educational Administration Andrews University

PROFESSIONAL EXPERIENCE:

1959-62 Teacher, Sunny Hill School

Sarawak, Malaysia

1962-63 Teacher, Sabah Adventist Secondary School

Sabah, Malaysia

i966-68 Teacher, Sabah Adventist Secondary School

Sabah, Malaysia

1969 Principal, Sabah Adventist Secondary School

Sabah, Malaysia

1973-74 Education Superintendent, Sabah Mission

Sabah, Malaysia

1975-78 Mission Secretary and Education Superintendent

Sabah Mission, Sabah, Malaysia 